Portland State University

PDXScholar

12-8-1971

\title{
The environmental crisis; the effects of ecology courses on high school students
}

Carol C. Fletcher

Portland State University

Follow this and additional works at: https://pdxscholar.library.pdx.edu/open_access_etds

Part of the Ecology and Evolutionary Biology Commons, and the Educational Assessment, Evaluation, and Research Commons

Let us know how access to this document benefits you.

\section{Recommended Citation}

Fletcher, Carol C., "The environmental crisis; the effects of ecology courses on high school students" (1971). Dissertations and Theses. Paper 1625.

https://doi.org/10.15760/etd.1624

This Thesis is brought to you for free and open access. It has been accepted for inclusion in Dissertations and Theses by an authorized administrator of PDXScholar. Please contact us if we can make this document more accessible: pdxscholar@pdx.edu. 


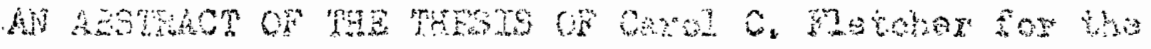

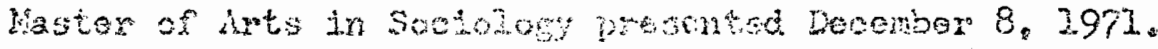

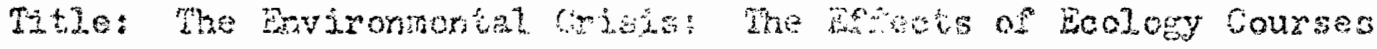
on Wizh Sehool Students

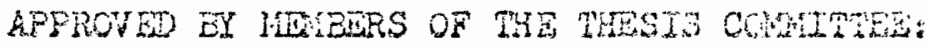

Bayry Lebowitu, Chasring

John Janes

$\operatorname{Jan} \operatorname{tin} \sin$

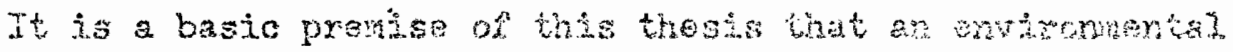

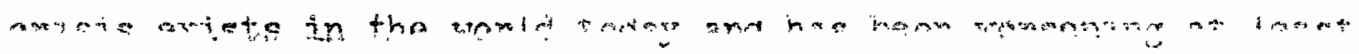

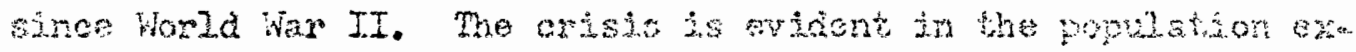

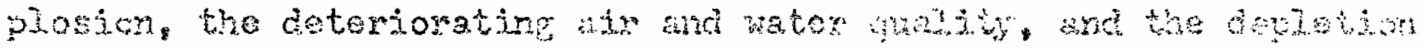

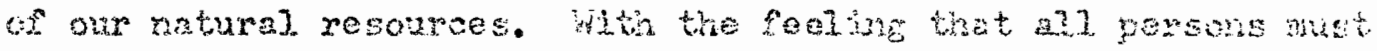

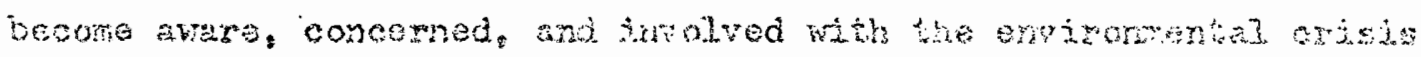
if the trond is to be aversed, this study is coneamen with ont

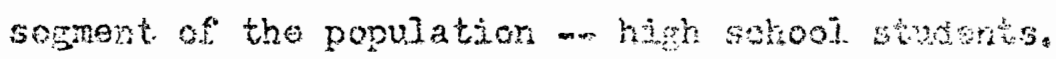

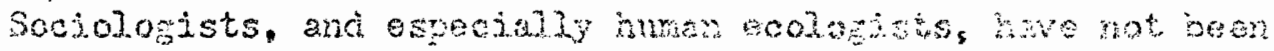

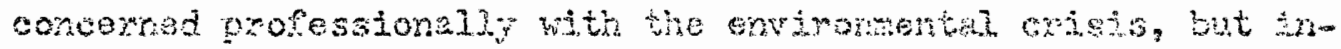
sterd with spatial distributions of phenomsna in citian mey have developed no theory that ha been partinent to hedping

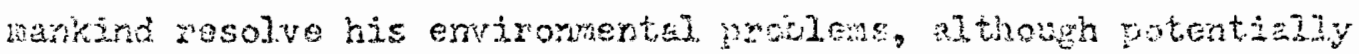


the fludd of human ocology and do so. 3ecause of the lack of such needed theory, suggections made to alleviate the ertsis have been discrganizod: population control, political action, economic action, and oducation. Fication, with the intent to generate data to fuide curriculun development, is the foous of this study. inj.s exploratory study trvostigated the awareness, concern, and involvenent of high school students with the environmental crisis. Tho groups of students were intemisend: those who had taken an ecolosy course (infomants), and those who had not (randism). A total of 98 students and 5 teachors were interviewed at tro Portland high schools, Reynolds and Aloha, in the spring of 1972. The interviews consisted of three partos: a ranking of the ingortance of ecological problems by the stucients using ecologieal pictures, followed by a discussion of the reasons for the orior: art interview using direct questions; and a gus thomaire sexing backround infometion. All interniens were tapo recorded. The dexa was coded, and statigtically analyzed by a computer.

The data jndicate that the ecology courses did influence the informants. The Reynolds informants tenced to viev atilitude change as the nost important task to alleviate ecological problens, whereas the Aloha informants saw the major task as reducing popuiation growthof rech of these views reflector the major emphasis of the respective courses the courses, wach with different activitios. ai so infurnced the ecological involvement of the informants in different wieys.

In background characteristics the tuformants tended to cone from smaller fanjies, noxe ofter had no reltigious preferenes, 
camped moro, and spent mox tine in wildewess aras than tho random students. The infermants wero similar to the random students in the followirs ways: educational backgrounds and occupations of their parents, length of time lived in their prosent home, enjoyment of outdoor leisure activities, and extent of travels. There is a difference in the awamens, concern, and involvement of the informarts as compared to the random stucients. Both groups ses an ecological crisis in the world and in the Pacific Noxthwest, and both are concerned about nan's chances of survival on earth, but they differ in the ressons they give and the problems they see. Informents were also more actively involved in ecological activities in school and outside of school. 


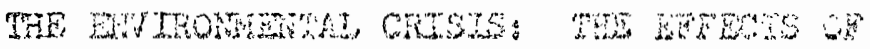

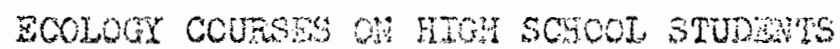

by

CAROL C. FLETCLIST

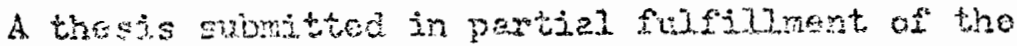
requirements $10 \mathrm{x}$ the degreo of

MSTRE OH ARTS

in

Sotologr

Porting state Whiveresty

3.91 
TO THE OFICE OE GRADUATI STUDTAS:

The members of the Comitte approve the thesjs of Carol c. Fletcher presented Decsmber 8, $29 \% 2$.

Barry Uebonita, Ghandian

Jorn Janes

Jan haja

APPPOVED:

Don C. Giztons, Fead, Department of Soctojogy

David . Clark, Lean of Graduate Studies

December 10, 1971 
TALE OF CONTENTS

PACE

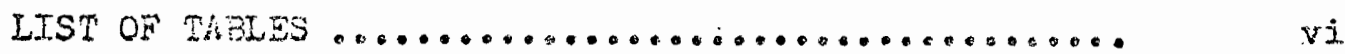

CHAPTER

INTEODUCTION ............................. 1

I IS THERE AN RINIROMMEUTAI CRISIS? ........ 4

Population size and Its Consequences 5

The Predictable Consequences of Population Inbalarice

Sumangy of Population size and ito lonesmences

Population and Food Supplies

Summary of Population and Fooch Supplies

Envircrmentas Pollution

Air Quastity

water quality

Rate of Use of Our Natural Resources

Simany of the Rate of Us of Our Viatural Resoliscos

II TIE ZNVIRONWENAI CRTSIS ............

Human Ecology ................ 28

Environmental Crisis vritings ...... 29

Needed: Eyrimonental Cxisis theory

What Can Ee Done to Rosolve the Enviromental Croisis? ........ 
Popviation Control.

Political Action

Economic Action

The Fole of Education

IIT DESTGN OF THE STUDY .................... 51

Introduction .................... 51

Instrunents Used .................. 52

filot Testing $\ldots \ldots \ldots \ldots \ldots \ldots \ldots \ldots$

Study Settings in the Portland Area 56

Sources of Data ................ 5 ?

Tabulation of Data............... 59

IV FINDINGS: DATE AND INTERPRETATION ...sosos 60

The Impact of the Enviromental Crisis

Courses on the Informants at

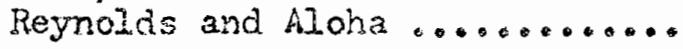

61

$\operatorname{Summan}=$

Background Characteristjes infomants and Raridon Students ..........

74

Sumary

The Awareness, Concern, and Involvement of Infomants and Random Students with the Bhviromental Crisis ..
Avareress and Concern of Informants and Rsudom Students

Ecological Involvement of Informents and Random Studerts

$V$ SULLAR, CONCLUSIONS, AND RECOMLNDATTORS 327

Sumary and Conclusions .......... 217

Fecommendations ............... 120 
APPENDICES

A. Student Background Information Sheet ..... 130

B. Interviev Guide n............... 132

C. Teacher Interview Guide ..............

D. Variabie Dictionary ........................... 


\section{IIST OF TABIES}

TALE

PAGE

I Three Nost Important Ecological Problems in

the World kecording to Informants ...... 6 ?

II How Informants Eecane Fologically Involved .. 69

III Beological Involvement of Informants at School

IV Ecological Involvement of Informants Outside of Scinool

$v$ Number of Coildren in Family - Tnformants and

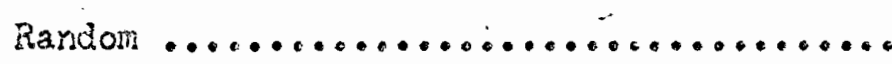

VI Length of Residence in Present Home ......... 76

VII ENucation of wother ....................... 7 ?

VII Education of Father .................... ??

IX Students' Religious Freferences ........... 78

$x$ Qutdoor Leisure hotivities ................ 80

XI Freguency of Trips to Milderness dxcas ...... 81

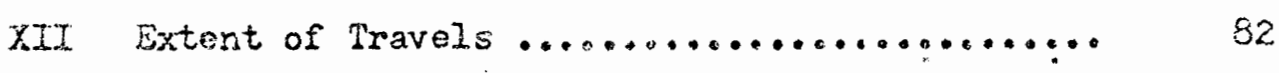

XIII Source of Eovlogy Infonnation f.......... 86

XI Major Interest in anvirommental Issues ...... 8 ?

XV Influentizl scology Readings ............. 89

XVI Informants' Reasons for Taking Course ........ 90 
XVII Roasons for Random Students Not Taking the

Ecology Course ..................... 92

XVIII Is there an Ecological Crisis in the worla? .. 93

XVIX Is There an Ecological Crisis in the Pacifte

Northwestr ........................ 94

XX Specific Problems Ventioned on hy an Ecologieal

Cxisis Exists in the Worli ............ 96

XXI Three Nost Important Ecological Froblems in

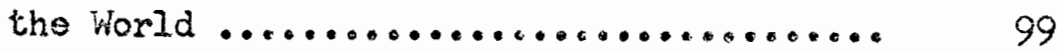

XXII thy Is Population A Problem? ............... 100

XXIII Does the United States Have a Population

Problem? ........................ 102

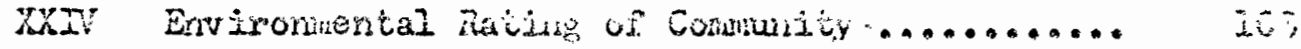

XXV Optimism Versus Pessimisn of lian's Chances

of Survive? $\ldots \ldots \ldots \ldots \ldots \ldots \ldots \ldots \ldots \ldots \ldots \ldots$

XXVI Envirominental Problems Can Ee Solved Ey

Technology ....................... 106

XXVII Ecological Problens in Picture 1.5? .......... 108

XXVIJI Ecological Insolvement in school ............ 210

XXIX Ecological Involvenent Cutside of Shool ..... Il]

XXX Willingness to be Involved in Life sityle

Changes ............................. 


\section{INTRODUCTION}

It is a basic assertion of tris thesis that an environmentel crisis does exist in the world todzy. This erisis has been growing at ever rapid ates since World War $I I_{\text {, and }}$ if a reversal of this trend in our environment is to occur, elI persons must not only be aware of the problems that exist, but also be concerned enough about the quality of life and man!s survival on earth to want to become involved in some manner to bring about change. One segment of tho population toward mom this specifically applies, and toward whon this study is directed, is high school students.

While there have hap many suggestione as to how to rocolye the environmental crisis, education of our children is commonly agreed to be one major way, or one major ingredient of a comprehensive plan. Developing curriculum on the environment is one specifie way of educating students about the environmental problems - not only giving them a sound basis of knowledge, but also toaching them ways to be involved in a constructive manner to bring about such changes.

This study is a beginning attempt to discover where some high school students are in their thinking and in thelp actions toward the onvironmental crisis. If curricuium is to be devoloped on tho environmental crisis (and beginning efforts have already been made by isolated teachers and schoois), one ought first to have an wderstanding of students' views on this subject. At, least shes possibllities aro 
apparsnt. If students are not aware of many of the onvironmental issues, this calls for curriculun development of one type. If students are very knowledgeable about the problems but are not concerned about them because they do not see these problems as serious, this calls for another type. If students are interested in the quality of their environment and would like to become involved in maintaining this quality, then curriculum developnent should consider this aspect too. Ninety-eight students and five teachers from two Fortiand area high schools were interviewad, and the results of these interviews are presented in this study. Only one previous study has been undertaken which sought to detemine high school students' concsm ijth ar environmental problem, and this was concerned only with air pollution. 1

Chapter I, "Is There An Environmental Crisis?," analyzes three

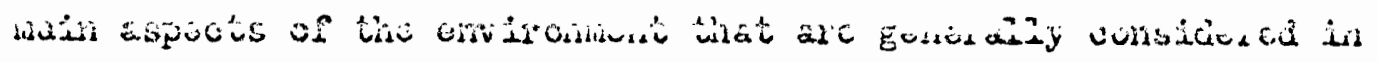
discussions of environmental quality: population growth and its consequences, air and water cleanliness, and the rate of use of our natural resources.

In Chapter II selected enviromental crisis writings are analyzed. Most of these writings have not been written by sociologists, and specificaliy not by human ecologists. In fact, human ecologists for the most part have not concerned themselves rith the enviroment, bit have spent their energies on spatial distributions of phenomena iribin cities. Trey, and sociologists in general, have not lod the ray in

${ }^{1}$ James A. Swan, "Response to Air Pollution, As Study of Attitudes and Coping Strategies of High Sulool Youths," invixonment and Eehavion (September, 1970), 127-53. 
cresting new ecological theory to give direction to empixical work on the environmontal crisis. In the absence of such theory, suggestions have been made for population control, political action, economic action, and for improved education, but tho suggested actions have been uncoordinated and not based soijdly on theory. This study is an attempt to develop a knowledgo base to coordinate ocologlcal offorts in curriculum.

Chapter III presents the specific nethodology used in this empirical study: the instruments used, the pilot testing resulics, the study settings in the Portland area, the sources of data, and a description of the tests and analyses used on the data.

Chapter IV presents the data and intempretations from three major questions that are asked: Did the two different environmental courses in the two different schools have a different impact on the students who took the courses? Is there a difference in the background characteristics of the informants as compared to the random students? Is there a difference between the informants and the random students or their ecological awareness, concem, and involvement with the environmental crisis?

The last chapter gives a sumary and conclusions of the study, and then makes recommendations for further studies to be concucted to determine for curriculum development the awarensss, concern, and Involvement of high school students with the environmental erisis. 
CHAPTER I

IS THERE AN ENVIRONMENTAL' CRISIS?

Is there an environmental crisis in the world? This chapter will examine some of the relevant facts and arguments in an attempt to determine whother indeed there is an onviromental crisis. of course, there are some who neither recognize a present crisis nor see one coming. Others are predicting the end of the human race in the near future. This chapter will attempt to balance these views to determine the degree of the present crisis, and whether the future frend is toward a lascened or more severe crisis:

Theie are three main aspects of the environment that axe generally considered in discussions of environmental quality: population size and its consequences (is there overpopulation?) air and water cleanliness (is there air and water pollution?), and the rate of use of our natural resources (are thay being depletedl).

A nomal ecosystem is, by definition. wtable and salfcorrecting; no imbalance is permitted to grow so large as to threstan the continued existence of any component of the systeri. in huran terms a crisis exists in the environmont of the world if either at present or in the near future the ocosystem of the earth is becoming unbalanced, and the predictable consequences of such imbalance are uracceptable. Specifically, if peoplo aro being born faster than 
they are dying, there is a population inbalince which unst be corrected to stabilize the ecosystem. If more pollutants are being put into the air or wator than are being removed, there is a pollution imbalance which must be corrected. If more energy and resources are being used than created, there is an imbalance needing correction. If for each of these the only correction which can be foreseen is unacceptable -. widespread famine, death, war, extreme regimentation and loss of freedom, or greatiy diminished standards of living, thon thore is a crisis.

\section{POPULATION SIZE AND I'SS CONSERUENCES}

In the history of mankind the increasing abundance of humanity is a rather recent phenomena, concontrated principally in the years from 1650 to the present, and largely the resilt of the agricultural and industrial revolutions. However, not only has there been an absolute increase in the number of people since 1650, but the rate of increase has steadily grown. Over these three centuries "the rate of growth increased from about 0.3 percent per year between 1650 and 1750 to 0.9 percent per year between 1900 and $1950 . " 1$ Since World War II the rate of growth has increased to around 2 percent. At this rate the annual increase of $70-75$ million persons, and the population of the world in the yoar 2000 would be close to 7 billion. At the 2 percent rate the present world population of 3.6 billion would double in only about 70 years. Considering that

${ }^{1}$ Philip M. Hauser, Population Perspectjues (Now Brinsrick, New Jersey: Rutgers University Press, 1950), P0. 5-7. 
it took centuries for the world population to reach 1 billion, oniy 80 years for this 1 billion to double, and now only another 80 years for the population to double again from 2 to 4 billion, the "population explosion" is an apt description.

Doubling Times: Estimated World Population Date

8000 B.C. 1650 A.D. 1850 A.D. 1930 A.D. 1975 A.D.

5 million
500 million
1,000 million ( 1 billion)
2,000 million (2 billion)
4,000 million ( 4 billion)

Time for Population to Double

1,500 years 200 years

80 years

45 yoars

$35-37$ years $^{2}$

There is clearly a population imbalance in the world ecosystem.

The Predictable Consequences of Population Imbal ance

Since Thomas Malthus in 1798 produced his "dismal thoorem"

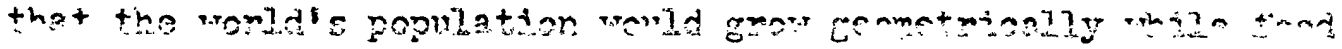
supplies would increase only arithmetically, the controversy has raged as to whether there is, in fact, a population crisis in the world. Malthus predicted that the only way for the imbalance to be corrected would be hard to accept -- widespread famino and death -and thus identified population growth as a crisis. Those who would dispute the proclamation of a crisis must show that the consequences of tho growth will be other than Malthus predicted - that tho imbalance can be corrected in acceptable ways. Colin Clark, ${ }^{3}$ the Eritish economist, is one of the more

2 paul R. Enrlich and Anne H. Ehrlich, Population, Resources, Environment (San Francisco: H.i. Freeman and Co., 1970), p.6.

3add Fisher, "The Many-Faceted Food Problem," Population Bulletin, XXIV, No. 4 (December, 1968), p. 85. 
reassuring persons on the question of the population explosion. Ho estimates that at the Arievican level of food consumption the world could hold 47 billion people. At the subsistence level, 157 billion people could be fed. If a critical point exists, he foels, it is fax in the future.

Others suggest eithor more acceptable solutions to population growth, or contend for other roasons that a crisis point is far in the future: there is much open land, forests, and forms in countries 211 over the world. Although some countries are very crowded, as India, others are not, as Australia, and migration could take place from one country to another. Uninhabitable lands could be cultivated for human occupancy as the Israelis have shom in the conquering of the Negev Desert. Countrios with high consumption of resources are now leaming to recycle, as the United States. Increased technology and the Green Revolution will be able to produce enough food for the vorld's peoples. The optirum population of the world varies with the individual; some persons living in large cities may not feel crowded at all. Movement of persons from cities to the rural areas would alleviate concentrated dense populations for those who do feel. crowded. And some even suggest that the figures on growth may be inaccurate, such as those for Red China.

Clark and othors also suggest that population growth is good in itself. Clark believes that the increased population competing for the earth's natural resources will have beneficial effects. It will "sharpen everyone's wits, as it 3lways has, evon if the level of innate 
the snviroment: detergencs in place of soap. nyion instead of wool and cotton, aluminum instead of steol, and plastic. Possony ${ }^{8}$ also supports the contention that the rorld environrental crisis is caused, in part, by technology.

People who see a population crisis are equally adanant and persuasive. For the most part they see the problems created by population increased and deny the likelihood that any of the ways of dealing with these problems suggested by othors will ever come about. Geore Borgstrom puts it: 9

The indisputable fact remains that we already possess on this earth more people than we are able to provide for adequately. At the same time that we are facjing this formidable task, we have to perform the reat of satisfying the needs of trice as. many human individuals in less than forty years. War has almost reached the point where, for all practical purposes. he is deprivine himself of any isctosy.

Persons despairing of solving problens resulting from population growth contend that economic development does not increase with increased population except in certain special cases. Kingsley Davis $^{10}$ states that econonic growth is difficult to achieve, and that only one country outside of Western tradition (Japan) has been ablo to achieve it. Most of the developing countries have found

${ }^{8}$ Stefan T. Possony, "Technology and the Human Condition," Ainerican Zehavioral Scientjst, ed. by R. Strausz-Hupe, 11(July, 1968). p. 43.

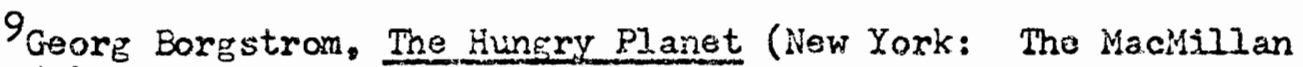
Co., 1965), p. 3.

10 Kingsley Davis, "Population," in Population in Perspective. ea. by Louise B. Young (New York: Oxford University Press, 1968), p. 130 . 
that the benefits of economic progress have for the most part been erased by the growth in population. To quote Jarrison Brown: ${ }^{11}$

The evidence suggests rather strongly that ir most underdeveloped countries the lot of the average individual has worsened appreciably during the last half-century.... People have become more poorly fed. There aro fewer available goods per person. And practically every attempt to improve the situation has been nillified by the relentless pressure of continued population growth.

Too dense a population destroys to a great extent tho productive capacity of its ecosystem. The overuse and exploitation of forests, minerals, and soils has already greatly reduced tho capacity of many parts of the world to support people, and there is almost no likelihood of reversing this damage.

These persons also argue that the costs in individual freedom are very great if population continues to grow. To many, the computerization of life, the treating of man as numbers, and the indifference of society to the individual are becoming intolerable already. 12 The individual would be much affected by the growing increase in population, because it means that he must become more regimented. Harrison Brown suggests the mechanism. As the increase in numbers of poople press on the available resources. this in turn will create the need for more elaborate organizations to produce enough food, to extract the needed natural resources, and to distribute the finished products. He hypothesizes that "the

11 Harrison Scott Brown, Janes Bonner, and Johr weir, The Next Hundred Years (liew York: Viking Press, 1.957). pp. $47-\overline{8}$.

12 Robert Rienow and Leona Train Rienow, Momont iri tine Sun (New York: The Dial Press, 1967), pp. 169-70. 
greater the population density of an Industriat society becomes, the more elaborate will be its organizational structure and the more regimented will be its paople."13 Social organization will become more complex and inflexible, the individual will have less opportunity to express himself freely, and the individual will have greater difficulty in finding privacy, quiet, and some open space.

The crux of the problem is the determination of the "optimum population" of the world. There is no agreement among anyone as to how many poople the earth can hold, and attempts at defining optimum population density have been nerely verbal abstractions, as for example: 14

The optimum density of population is that density at which a society in a given state of culture is able to utilize the resources of its habitat most efficiently. Tno cpiinum density of powitaition necessarily varies with the state of culture and with the amount and kind of available resources.

The question, of course, is not so much how many people the earth can support, but what is the optimum number from the standpoint of the possibility of a good life. ${ }^{15}$

Summary of Population Size And Its Consequences

Everyone who has studied the population problem agrees that

13 Harrison Scott Brow, The Challenge of Man's Future: An Inquiry Concerning the Condy fion of tian Diring the Xears That Lie Ahead (New York: Viking Eress, 1954), p. 250 .

14 Lse Raymond Dice, Man's Nature and Nature's Vian; The Ecology of Human Communities (Arn Arbor: University of Michigan Fress, 1955). p. 129.

15 Joseph Woad Krutoh. "A Naturalist Looks at Overpopulation," in Population in Perspective ed. by Loulse E. Young (New York: Oxford University Press, 1968), p. 395. 
the rate of population growth has been increasing. To this degree they all. agree that eventuelly something must be done to correct this imbalance. Their differences 1 is in the period of time berore this increased rate will create a population crisis. Some sec a crisis now, whereas others see any crisis, if at all, not coming for many years. The latter group thinks we both have time to find correctives for the imbalance, and that for the near future the gains from population growth outweigh the liabjilties.

If wo consider survival of mankind to be the most important thing -. survival not just for the short term but for the long mun ..then something must be done about the imbalance in population growth. The long run survival of mankind with scme capability for a good Iife will be dotermined by such factors as man's abilities to feed himself, man's success in preventing wars, the amount of freedom and Integrity each Individual human being is allowed, the prevention of exhausting the world's natural resources, and the preservation of a quality environment satisfactory for all inhabitation. The crux of the crisis is population imbalance: 16

When one of the worst disasters of the twentieth century occurred in East Pakistan in the fall of 1970, an estimated half milition people wexe drowned by a great tidal waye. Yet it took only $35-40$ days for Pakistan's population to exceed the number it had reached the day before tho disaster...:

Those who are not yet bothered by population growth suggest some Inaginative possible vays to handle increased population. However, the fact is that we have not yet manacea to implement

${ }^{16}$ Rufus E. Miles, ir., ed. "Man's Population Predicament," Populatior Zulletin, Vol. 27. No. 2. (April, 1972), p. 4. 
anything like their suggestiens -- mass population migrations to empty areas of the world, growing food in deserts, vastly increasing food output. In the face of evidence to the contrary persons who have confidence in solving the population problem are willing to risk not treating population Erowth as a problem now on the hope that their suggestions will ho able to be implemented. Is it a high risk? Would it not be better to deal now with correcting the population imbalance? Would that not make all the other suggestions so much more beneficial? It is to these questions that we now turn.

Population And Food Supplies

What is the likelihood that food supplies can increase faster than population growth? There has always been a fock-population

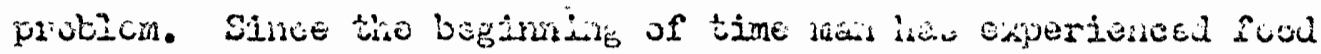
shortages, hunger, and starvation. This was just, as true when civilizations were confined to a few fertilo valleys as it is today. But today a failure in food supplies threatens the future of our entire civilization in an inter-dependent world. ${ }^{17}$

What is the likelihood of failure? Today world food supplies are rising at an average rate of one percent per year, while conservatively estimated, world populations are rising at moro than 1.8 percent per year. ${ }^{18}$ The extent of malnutrition at the present time is already staggering. Twowthirds of the world's people live

${ }^{17}$ Orville I. Freeman, World Withour Hunger (New York: Froderick A. Przeger, 1968), p. 3.

${ }^{18}$ Lloyd V. Berkner, "Man Vexsus Fechnology," Population Bulletin, XXII, No. 4 (Novorber, 1956), p. 83. 
in countries where average diets are nutritionaliy inadequate, most having fewer than 2200 calories per day. The following table is based on the most favorable estimates, which assumes a $I$ percent increase in annual food production. 19

\begin{tabular}{|c|c|c|c|}
\hline Year & $\begin{array}{l}\text { Total World Calories } \\
\text { (billions) }\end{array}$ & $\begin{array}{l}\text { Population } \\
\text { billions }\end{array}$ & $\begin{array}{c}\text { Calories Per Person } \\
\text { (per day) } \\
\end{array}$ \\
\hline $\begin{array}{l}1965 \\
1970 \\
1975 \\
1980 \\
1985 \\
1990 \\
1995 \\
2000\end{array}$ & $\begin{array}{l}7.000 \\
7.357 \\
7.732 \\
8.126 \\
8.541 \\
8.977 \\
9.435 \\
9.916\end{array}$ & $\begin{array}{l}3.3 \\
3.6 \\
4.0 \\
4.5 \\
5.1 \\
5.7 \\
6.6 \\
7.4\end{array}$ & $\begin{array}{l}2,121 \\
2,0914 \\
1,933 \\
1,806 \\
1,675 \\
1,575 \\
1,430 \\
1,340\end{array}$ \\
\hline
\end{tabular}

1340 calories per day ropresents a starvation level for pooplo and it also assumes that the calories are evenly distributed, which they wowl net he. [wijth the projection that in 35 roars tho popluation will double in the world, and barring some miracle jump in food production, the numbers of hungry just will not be able to be fed. The Enrlichs 20 and the Paddocks 21 both predict famines in the 1970's where millions of people will dio, in spite of any crash food programs that might be developed. They soe no way in which this mass starvation can be prevented. As it is bluntly put by one present day writer, if all of the food in the world wero ecually

\footnotetext{
19 Ibid.

20 paul R. Ehrlich, The Pooulation Bomb (New York: B3llantine Books, 1968).

21 Willian Faddock and Paul Paddock, Famine - 19751 America's Decision: Who Will Survive? (Boston: Littile, Brown and Company, 1967).
} 
against the present 75 bushels; milk projuction soaring to 30,000 pounds per cow from today's 8000; and agricultural production in general increasing over four tines during this period. Many now ideas have also been generatod for now kinds of food made out of substances never used before. Fish proteth concentrate, a high protein powder wade from othorwise inodible fish is such a ner food. Many also place great faith in harvesting tho sea and developing agriculture in now uninhabitable places.

But it is hard to see those optimistic idaas as persuasive. They are predictions without any historical besis, and even some of the recent siallex increases are interpreted in a questionable way. Faith in the Green Rovolution was inspired by increased production in such cointries as Iran. Covlon. Pakistan. Thrikev, and India, but it resulted not only fron new high-yielding varieties of sead, but by excellent woather conditions during that period of time, which combined to give these countries record crops. Of course, poor weather can greatly decrease such production. Fish protein concentrate. hailed as one of the most hopeful possibilitios for tide future, has not proven yet to be very usoful because of the tromendous expense of production. $^{25}$ Most experiments attempted in new agricultural Iands, unsuitable before for agriculture, have onded in failure. Harvesting the sea hardly holds much promise for the near future, if at all. 26

25"To Fill the World's Es11y," Science lews Letter, Val. 96. No. 19 (November 8, 1969), pp. 422-3.

26 William E. Ricker, "Food From tive Sea," in Resources and Man, A Study and Recommendations, ed. by Committes on Rosources and Man (San Francisco: W.i. Freenar and Co., 1969), pp. 87-10?. 
A roore realistic forecast for required food production is grim: 27

Between now and 1985, 85 out of every 100 pocple born will live in underdeveloped nations. These nations will have to increase the ir food supplies at least 80 to avold famine. The rising income of the urderdeveloped nations actually makes matters worse: As people bocome weal thior they demand nore food, so the total increase in demand for food by 1985 will be closer to $140 \%$.

"Malthus's approach -- identifying tho basic elements ossential to a solution and adopting practical steps to implement them -- is badly needed in a world where 1.7 billion men, women and children are perilously close to starvation." 28

\section{Surmary of Population and Food Supplies}

All persons concemed about the population-food situation would agree that if the world's poople are to bo fed, agricultural pivaluciojon wiIl have to continue to increase at a rate at jeast equal to the rate of population growth, or the population rate will have to lower to meet the food production rate. The possibility of either one of these occurring in the near future is slim, at least based on current trends. Then the world ecosystem is considered, the prospects for the future of feeding the world are not good -some countries may survive but at the expense of others. As there is an imbalance in the fooci-population rates, it is fair to say that a food crisis does indeed exist in the world. The most hopeful approach would seem to be to act directly and massively to cut

27"To Fill the World's Belly," Sciance News Letter, po 423.

28 Robert C. Cook, ed., "isalthus in Retrospect, The Stork Visits Dorking-1766," Population Julietin, XXII, No. I (February, 1966), p. 5. 
population growth, and to do it now.

\section{ENVIROMMENTAL BOLLUITON}

Fes poople would axgue that there is no air or water pollution. for most everyone has felt the effect of smog in the air or has seen a polluted river. The issus again is whether the amount of air and water pollution has reached a crists. The issue hore is one of degree and one's view of the degree of crisis depends on predictions about inether the problems of air and water pollution can bo resolved before it is too late, before the pollution oreates unacceptable consequences.

\section{Air Quality}

Fitu has been emptyare poilutants inte the air ever sines he appoared on earth. However, in the past tho natural cloansing mechanisms of the earth could keep up with the pollutants. In recont years, with such emphasis on economic growth and progress, the quality of our environment has been deteriorating. The iricrease in pollutants is outstripping the natural corrective cleansing mechanisms.

In the United Statos alone, from 1046-1968, the use of automobiles increased by 200 persent, but the index of nitrogen oxides. a major ingredient of smog. jumped 630 percent. ${ }^{29}$ The consequences for the future are going to be worse than at present, if the prediction that the number of automobilos in this country will quadruple by the

${ }^{29}$ Stanford N. Sesser. "The Nation Debates An Issue: The Economy vs, the Invironment, "The Wall Streat Jolund. Novomber 3, 1971, p. 18. 
year 2000 . comes true. 30

The earth has only a finite supply of air and water, yet raroly give forsthought in anticipating wat Lovering calls the "what-olse-do-you-get" 31 consequences of the changes that we bring to our air and water. The result is that there is just not enough air and vater on the earth to absorb tuday's manmade wastos without effect.

The quality of air is extrenoly important. Not only mist we have clean atr to breathe, but we must have a constant supply of it. Lafiont Cole sees both aspects in jeopardy: 32

We are absolutely depondent on oxycen which is produced outside our borders -- mostly in the Pacific Ccean ... and brought in by atmospheric circulation. If we should inadvertently kill enough marine diatoms or the organisms they depend on for fixod nitrogen, we vould start running oui cis oxigen io breatio.

Wo have been dumping chemicals and DDT into the ocean, and the problem is that we do not know exactly what offect this dumping is having on the marine diatoms or the organisms they depend upon.

But to what degree is there a crisis? Unfortunately, this is hard to determine, and most writing has merely stated the problem. For example, few can disagreo with Commoner's description: 33

30

Ibid.. p. 123.

31 momas S. Lovering, "Mineral Resources from the Land," in Resources and Man, ed. by the Conmittee on Pesourees and Man (San Francisco: i.H. Freeman and Co., 19,69), p. 130.

32 LaNont C. Cole, "Man and tho Air," Population Bulletin. Vo2. XXIV, No. 5 (December, 1968), p. i10。

33 Barry Cosmoner. Scionce and Survival (New York: The Viking Press, 1963), p. 122. 
by aix pollution, "thore is an ever-mounting secumulation of evidence linking the two."35 This period from 1950 on is a period of rapid urbanization and the djsease has boen mozt oiton found among city dwellex: 3 ?

Dr. Midileton, Director of the National fir Pollution Control Administration. was asked tho quostion, how urgent is America's pollution crisis? He responded the following: 38

It is one of the nost serious enviromental problems wo've ever faced. In cur cities whero it is most severo It makes healthy people 11]. It obliterates the skyline and dostroys netural and manmacio beauly. It kilis plants, causes disease in aninals, corrodos steel, rots draimpipes, discolors fabrics. fir pollution may also be changing our clinate in adverse vays. You name it, it happens.

Dx. Middleton's response relates to the United States, but air pollution knors no political boundaries.

\section{Kiatos Quelitu}

Is the quality of the vorld's wator in es sorious a crisis as that of the air? Cleasly more pollutants are being discharged Into the rorld's bodies of freter than the natural cleansing process can handle. At some point this imbalanco must be corrected. As with population grosith and air quality, the question of whether

36 Lawis Herbor, Cxjsts in Our Cities (Rnglewood Mjfrs, New Jorsey: Prentice Hali, inc.. 1965), pp.66-8.

37 Cre such study was is jersey City. Seo Thonas M. Cocke. H.D. "What Is the Role of Air Pollution as a Cause of Disease?" Amerioan Jourrel of Publie Health, Supplenent to January, Vol. 54. Lio. I (vanuary, 1964), po. 71.08.

38 John T. Midleter. "The Air Wo Breatho," population Burlotin. XXIV, No 5 (Dicsmber, 1968), p. 125. 
there is a crisis in water quality is one of degree. Very little water any longor is pure. po some degres then virtually all water is polluted. But is the degree of pollution a crisis? Are we at the point where if the process is not roversed, the consequences will be unacceptable?

Swiming holes unavailable for swiming, fish inedible because of excess mercury, or other pollutants, oil slicks lining the coast lines of nations, the near extinction of some sea life as the gray whale, and water unsuitable for drinking, are all indicators of a crisis in the water supply of the world.

Unfortunately, there is no goed measure of at what point water should be considered polluted. Many bodies of water are considered unsafe for swimming, but the degree of pollution used to determine danger often varies widely. Most untreated water is considered unsafe for drinking, but again in some areas of the world people can tolerate a much higher degree of impurity thar in others. Manj bodies of water have either no fish, or only tiash fish, or fish which are inedible because of excess mercury or DDT. Oil slicks Iine the coasts of many courities.

If safety for drinking is the criterion, virtually all natural. bodies of water are polluted. If sinming, or arinking are the criteria, almost every large vaterway in tho United States (Potomac, Delaware, Mississippi, Chio, Kudson) as well as around the world (Fhine, Ganges, Tiber, Soine) and many lakes are polluted. If we require only the existence of edible game fish, a distressingly 
Iarge number of rivers would still be congidered polluted (they have none).

One difference botwe air or water pellution, and population growth, is that no one argues that there are any beneficial side effects to pollution. The only reason not to act to decrease pollution is immediate economic cost, and evon here the question is debatable. The immodiate costs of polzution may far outweigh the costs of cleaning up the air or water. Wo may nocd only to figure out how to divert the costs of overcoming the effects of pollution to preventing it.

If water is a primary resource, and if the supply and condition of our water supply is a vital physical index of a nation's wellbeing, then, in the past few years we have suffered a very sharp

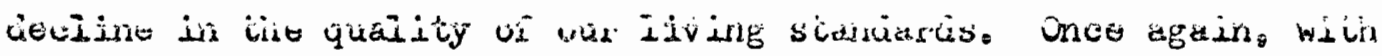
increasing numbers of people in the vorld, and with nations desiring to become industrialized to take care of their expanding populations, the problems of water supply and water pollution will becane even more serious than they are at tho present time. 39

RATE OF USE OF OUR NATURAL RESOURCES

One of the great delusions of mankind throughout the centurles has been the belief that the natural resources of the earth are inexhaustible. The population explosion along with increased industrial expansion has created the need for more of the world's natural resources; mineral, fuols, lumber, and energy -. all of which

39 Brown, The Challenge of Man's Riture, p. 214. 
are finjte in amount. 40 is with population and pollution, no one disputes that our rate of use of resourses has increased. The question again is, to what degree are we facing a crisis? Are we in irminent danger of ruming out of resources?

Some analysts do not see our natural resourcos as in a crisis state. There have been as yet no world-wide scarcities of resources as Malthus had predicted, and world trade has made it increasingly possible for countries with shortages of certain kinds to import from other countries. The rinespread advarce in technology has made possible the mining of deposits that were once thaught inaccessible. Also, better ways of processing and using raw materials have stretchod the usefulness of a given quantity. 41 Those persons who have confidence in world trade and technolozy also feel that there is still sufficient quantity of most natural resources in the world. At worst it will simply take more effort and more money to got them out for Lise.

If scarcity of natural resources can be thought of in terms of cost rather than of phosical elimination, since the less good resources which are left will take more money to extract, the issue of quantity versus quality is a very important one. 42

Problems of quality...are just as important as the problems of quantity and probably more dificicult. Simply

40H.B. vanLoom, "Fopulation, Space, and Human Culture," Law and Contemporary Problerns, Vol. 25 (Summer, 1960), p. 400.

41Hans H. Iandsbere, Natural Rescurces for U.S. Growth, A Look Ahead to the Year 2000 Teaitimore: Johns Sopkins jress. published for Resources Fan the Future, 1964), p. 4.

$$
42 \text { Ibia.. p. } 13 .
$$


having enough oil, metals, land, and water would not spell a. satisfactory life for nost peopls. For oxample...pollution of water does not usually provent its use, but it does make use less pleasant and more costiy. The reletionship of people to resources, which usually has been expressed in terms of quantity, noads to be restated for modern tines to emphasizo what is happoning to the quality of resources.

On the other hand. the question still remains: At any lovel of quality how long can the natural resources of a finite world support increasing populations at rising levels of living? The United States will probably be able to continue to extract low grade ores, or perhaps to develop substitulos for them, for a substantial period of time, but for the underdoveloped countries of the worid who do not even have the finances to foed their pooplo, the problem of finding sufficient resources is more critical. Landsberg, evon for tho United States, recognizes that resoures supplies will continue to neet noeds only if three assumptions exe ret: continuing gains in technology, improvements in political and social distribution procedures, and a reasonably free flow of world trade. 43

The widening economic gap between tho developed and the underdeveloped countries will almost certainly grow if resources are only available to technologically advanced, well organized, wealthy countries. inile it may not be tho ain of the United States. or for that matter any other country, to soe this gap widened anymore than it is presently, the rapid use of resources may forco this gap to widen. The United States, in particular, a.s well as the rest of the world, cannot continue to grow in population and in industry

$$
{ }^{43} \text { Ibid.. p. } 6 .
$$


without having adverse affects on the natural rosources of the world, If all countrios had tho standard of living of tho United States, it would have severe consequences for the natural resources of the world: 44

-..before any area can roch tho per capita energy and mineral consumption rate of the united stetes, it must first build up its industry to that level. Foro the whole world to have done this... the presently estiniated world supply of the ores of most industrial netals, producible by present technolofy, would have been exhausted well before such a level of industrialization could have been reachod.

Sumary of The Rate of Uss of Our Natural Reseurces

All who have studied the rate of use of our natural resources agree that many of our natural resources are either running out or are becoming more inaccessible, thus more expensive to oxtract. But same do not ace tho problom of axtracting thean wore hardutomgt resources as critical. Perhaps it is assumed that tho wealthier nations will do the extracting and then supply the rest of the world. The cost would bo expensive to the purchaser no matter who did the extracting. It seems unreasonable to expect the poor countries of the world to be able to pay for these resources; their money resources are needed now for the essentiels of life - food and shelter -- as well as for industrial developnent. These countries do not have the means for extracting this more inaccessible and more low-grade ore, let alone the means to pay someone else to do it. And the walthier nations cannot continue to support the

"4harlton Ogburn, Jr., "Why the Glcbal Income Gap Grows Wider," Population Bulletin, XXVI, No. 2 (Juse, 1970). p. 5. 
poorer ones without adverse consequences. And if the poorer countries develop rapidly, the shortage will become acute all the more soon.

Yos, there is a crisis in the rate of use of our natural rosources bocause there are timbalances in whe can use them, and in the rate of use. Unless new sources of erergy are fourd, resources will increasingly bo available only to the veal thy and advanced.

\section{IS THERE AN ENVIRONMENTAL CRISIS? CONCLUSION}

There is indeed an envisonmental crieis on many fronts of the world: overpopulation in nany areas and the numbers of people Increasing; deterioration of the quality of our aix and water; and rapid use and depletion of our natural resources that are finite in gualty and quanthty, Unfortunotoly, if a person limitod his readinge to sociology and particulariy to human ecology, he would hardly realize that an environmental crisis did exist in the world, because most of the writings which have dealt with the crisis have not come from sociologists but from other professional fields. 
CHAPTER II

THE INW IRONMENTAL GRISIS

There aro tro major kinds of man-envirunment writings -. those that were undertaken by the human ecologists, beginuing in the $1920^{\prime} \mathrm{s}$; and those that wore written by 'alarmists,' beginning after World wis II. Both kinds of miting focused on the manenvironment relationship, both used many of the sano statisties. but the enviromental crisis writers began asking of this relationship very different kinds of questions than had been asked by the human ecolorists. The first section of this chapter reviews this work. The secona part of this chaptex will jook ax some of the suggestions from these writings that have been made to help resolve the environmental crisis: population control, political action, economic action, and education. Education, particularly curriculum for high schools, will be emphasized, as it is the major focus of this study.

HUMAN ECOLOCY 1

The field of human ecology began in the $1920^{\prime} \mathrm{s}$ at the University of Chicago through three major men -- Robert E. Park.

1 A much more detailed analysis of human ecology, its theoretical framerork, its major theoreticlars, and possible slizgestions for new theory to help rosolve the envirommental erisis can be found in Carol C. Flotcher. "An Analysis of Iuman Ecology Theorios," (unpublished theoretical paper, Departwent of Sociology, Portiand State University, 1971). 
Ernest $\mathrm{H}$. Burgess, and Roderick D. McKenzie. Human ecology became the major component of sociology, dominating the field with its tremendous quantity of empirical studies, usually undertaken in the eity of Chicago. The prime focus of human ecology during this period was the spatial-locational distribution of phenomena within the city. Through the jears human ecology maintained this focus, even though major ecolofical theorists, as Amos it. Hawley, Janes A. Quinn, and otis D. Duncan, have enlarged upon the original theoretical formulations. The literature in human ecology is Iargely composed only of duplicated studies. The field has never gone beyond spatial distribution studies, never developed new direction or theory, and consequently the field has declined in stature, sigrificance, and relevance.

One potential area for now tneoretucal development in human ecology is the environmental crisis. Unfortunately, very few human ecologists in particular, and sociologists in general, have dealt with the environmental crisis. Instead, most of the writings on the environmental crisis have cone from specialists in other fields of endeavor.

\section{ENVIRONIEITAL CRISIS WRITINGS}

Although people have been writing about the problems of population since the turn of the century, it was not uncil 1948 that Fairfield Osborn wrote our Plundered Planet, ${ }^{2}$ the first major

\footnotetext{
2Fairfield Osborn, Cur Plundered Planet (Boston: Little, Erown, and Co., 1948).
} 
book on the environrental crisis in its totelity. Since this publication, the number of articles and bogks on the deteriorating relationship of man to his environment has increased rapidly. Tho books and articlos have contained much quantitative data, but although some have used the major ecological concepts in their writings, these ecological concepts have not been the basis for their conclusions, or for their point of view.

These writings on the environmental crisis have been produced by scholars in all fields of endeavor: biologists, oconomists, scientists, naturalists, and sociologists. Some of the books and articles have had groat influence, though not necessarily at the time of their publication. Others have creatod tremendous controversy upon publication as Silent Spalne, The Population Bomb, and Fanine -

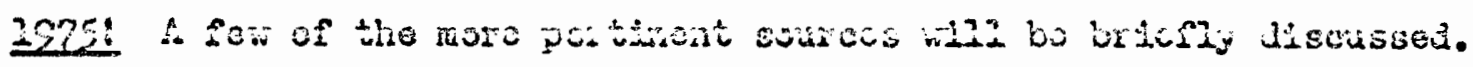
"An early warning wisch, unhappily, was ignored," 3 is Paul Errlich's evoluation of Osborn's Cur Plundered Planet. Wan is not detached from, nor all powerful over, his enviroment, claimed Osborn. and if ho is blind to tho needs of co-operating with nature, he will destroy the sources of his life. "All the component parts in the machinery of nature ars dependent one upon the other. kemove any essential part and the machine breaks down. This is a prinary fact and there is no other comparablo to it in importance. "4 Man cannot be supported on earth by artificial processes and he must be aware

3Paul R. Ehrlich and Anne H. Drritich, Pooulation, Resources, Environment (San Francisco: W.H. Freeman and Co.. 1970). p. 362.

4osbown, Our Plundsred Planet, p. 48. 
of the potentially selfudostruetive inpact that he has when he destroys the earth's resources.

The destructive inpact of nan on his environment in the United States has been particuiarly strong, continuos Osborn: 5

The story of our nation in the last century as regards the use of forests, grassl.ands, wildilfe, and water sources is the most violent and the most destructive of any written In tho long history of civilization. The volocity of events is unparalleled and we today are still so near to it that it Is almost impossible to realize what has happoned, or, far more importent, what is still hapooning. Actually, it is the story of human energy unthinking and uncontrolied.

Feeling that the majority of Americans did not know or were unconcernod about the environmental crisis, Osbom sought to develop new interest on the part of the public to bring about changes by pressuring legislators. He feared then, as many do now, that it

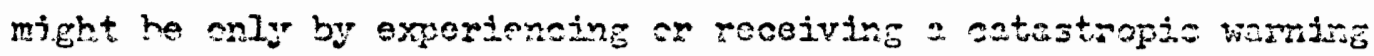
from nature that man would bo stirred into action. The most important and most difficult task in 1948 wis to arouse public opinion, and this would take coordinated effort on the part of government, industry, and education. He found it extraordinary then that so few schools and colleges had conservation courses. The Hext one Hundred Years, ${ }^{6}$ written in 195?. came to the following conclusions based upon data that tho authors analyzed: 1. The industrialization process will continue at a rapid

5osborn, our Plundered Planet, pp. 175 a.6.

6 Harrison Scott Brom, Janes Bonner, and John Weir, Tho Next Cne Hundred Years: Wan's Natural and Tochnological Resources, A Discussion prepared for Leaders of hnerican indusiry (itew York: Viking Press, 19.57), pp. 42, 50-1, 68-9, 94, 102, and 112 . 
pace and many decades will bs needed before the per capita levels of consumption throughout the world approach those of the West.

2. Rapid rates of population growth can be maintained only if food production can ksep pace with population growth. This is doubtful.

3. Increases in foos can bo attained through improved technology, and should bo able to take care of the population. if world population becomes stabilized at between ? = 8 billion persons, and at standards lower than those of the best-ifed persons today.

4. As processing of more and more lorer grade ores increases, capital investments per unit of metal output must necessarily increase, as must also energy consumption per unit of output.

5. Tho unoven distribution of some fossil fuels, as coal, has, and rill continue to create nore energy probiens in the future, although there is theorotically sufficient coal in the worla to last man for quite awile.

6. There are potential sources of energy to last man for a Iong time, al though these resources have to bo transformed from potontial sosourcos into acturl oros.

7. The production of scientists and engineers can be increased as can be their brain usage to develop more technology.

8. In the next century the problems of mankind are less those of technology than of man getting along with man. A world of abundance and creativity can exist if man rorks together, organizing themselves to work together to solve the problems that confront them.

The conclusions of Brown et 21 . In 1957 have been confimed. supported, and substantiated since then by many other writers and scholars: man must recognize the problem of his deterioreting environnent ard do something about it, or his survival nay be in question.

In 1962 came perhaps the most influential book over written on the topic of man's relationship to his onvironment, Silent Spring.?

PRachel Carson, Silent Syring (Greentich, Connecticut, Farcett Publications, Inc., 1962). 
Rachel Carson is quoted more frequently than any other person in prosent day environmental-ecological writings. Wer book is an attack on the contamination of the environment with lethal pesticides. In story after story, incident after incident from around the world, she spells ant tho disastrous effoct that the indiscriminate use of pesticloes has hed on the soil, the rivors and soas, and the air. For the most part she saw this use of chomicals as creating an irreversible process -- damage would be cone, or had been done, that either could not be corrected, or that set forth other processes of destruction; jn poisoning the caddis flies in a stroam, the salmon runs dio out; in poisoning a lake to kill gnats, the birds who feed on the gnats eat and die; in spraying the elns with poison, the robbins die, not because thoy wore sprayea with poison but because line posson travelea to the eartn to the earthworm and thon to the robin.

As crude a weapon as the cave man's club, the chomical barrage has been hurled against the fabrio of life -2 fabric on the one hand delicate and destructible, on the other miraculously tough and resilient, and capable of striking back in unoxpocted ways. Those axtraordinary capacities of life have been ignored by the practitioners of chemical control wino have brought back to their task no "high-minded orientation," no humility before the vast forces with wich they tamper. 8

of the recent writers on the environmental crisis, there is perhaps noone as outspokon as Paul Ehrich, nor perhaps as widely read. The Pooulation Banb 9 has been reprinted many times since

Inid. pp. 251-2.

9paul Wnrlich. The Population Bont (Now York: Ballantine Books, 1968). 
its publication in 1968. It is readily avafiable in most bookstores and has been widely used in courses in high schools and colleges. Ehrlich's major conclusions are pessimistic; man's time on earth is limited because of man's great apathy stout the problems facing him. Enrlich prodicts mass starvation in the 1970's, and he finds the environment becoming intolerable for existence. Some countries, like India, he considers hopeless. Ho suggests abandoning it and countries like it, and concentrating on trying to save those countries that still have some glimmer of survival possibilitios. The Ehrlichs' latest book published in 1970, Population, Resources, Environment, is much more quantitative than The Povulation Eomb. In it they look with care at the requisites of life that are in shortest supply for a population: space, heat, available energy, nonrenowablo resources, water, and food; and with skepticism that needed quantities of these can be provided. Called an alamist by meny critics, Paul chrlich nevertheless has been heard.

Needed: Bnvironmental Crists Theory

Human ecology writings are largely irrolevant to the environmental crisis. Human ecology has not providad theory to help man explain ecological relationships, to contribute to our awareness of ecological imbalances, or to contributes to our knowledge of how to act to resolve the present and worsoning environmental crisis. The environmental crisis writings have increased in quantity too rapidly to be abscrbod. And like tre empirical studies in human ecology, the environmental crisis writings are repeating the same 
data in ane journal after snother. New ecologicai theory on the environmental crisis is needed to help synthesize and organize the tremendous quantity of information that has been written since 1948.

WHAT CAN BE DONE TO RESOLVE THE FWVIROMENTAL CRISIS?

In the absence of the needed theoretical formulations, wo know little of the likely effectiveness of various suggested solutions, nor the size of the effort necessary. Still, the surface plausibility of some of the proposals argue for gotting on with them, even though theoretical understanding is some time off.

There are many suggestions of what can be done to help alleviate the environmental crisis: population control, more political pressure on the government, a decrease in overconsumption and "growthmania,"

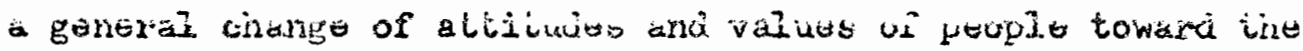
environment, and education of the general public about the environrental crisis. Education is a major and irportant suggestion, as it underlies any hope of change in several of the other areas. If education is successful, it can create an awareness and concern on the part of the population about the crisis, and then motivate them to become involved in tryine to resolve the problerns.

There can be no more urgent task than that of spreading knowledge of mankind's truly precarious situation. Fublic education on the broadest possible basis is callod for from the first grade right up through our academic institutions. filthough it may be one hundred years too late, we night still have a chance to save man and, possibly, civilization. But without a large-scale educational drive, our frantic mush downwaxds with a constantly accelexated speed cannot bo slowed up or, better still, switched into a smooth clinb 
for prosperity, progress, and human bettement. 1

Nany others join Borgstrorn and mysolf in tho plea that the greatest challenge facing the schools today is the necessity of educating children about tho enviromentai crisis. ${ }^{2}$ It is crucial that mankind not only be bnokledgable about the environmental crisis, but concerned onough about thoir and futire generations' survival to want to do sometring about it now.

Sir Francis Bacon once said: "To loarn to dominate Nature we must first learn to obey her." 3 It is crucial that mankind develop an "ecological conscience," that he learn and understand tinat he is only one part in a grat biological scheme, a web of Iife, and that his continuod survival will depend upon a close working relationship with arnar angentams sud with tho totsl environment.

Man is not an isolated spenes living alone, but is dependent upon numerous associated species of plants and of arimals for food and for many of the other ossentials of life. Mian 31 so is directly or indirectly dependent upon the physical concitions that cocur in the habitats in with he lives. All. the biotic and physical factors that affect man are complexly interrolated. 4

${ }^{1}$ Georg Borgstrom. The Lungry planet (Now York: Tho Nackillan Co.. 1965), p. xx.

2Also see Garrett, DoBell, "Bducation and Ecology," in The Environmental Honibook, ed. by Garrett DoBell (New York: Ballantine/ Friends of the Barth Eook, 2970). pp. 129-33; and "population Education - Evolution or tevolution," Population eulletin. Vol. XXIV, No. 3 (ivashington, D.C: Population Referonce Eureau), pp. 3-40.

3 Robert Rienow and Lacna Train Rierow, Foment in the Sun (Now York: The Dial Press, 1967). p. 38.

4 Is a Raymond Dice, lian's Nature and Oature's inan: The Ecology cf Yuman Communities (Ann Mrbor: University of tentigan Press, 1955). p. 298. 
İan, however, has not followed Sir Francis Bacon's advice, but has through the years had the attitude of superiority over nature. Whatever reasons for this attitude, 5 religious or otherwise, man needs now to develop an ecological ettitude which admits that he is the nost poweriul species on earth, but because of this, he must accept the role of consciously maintaining and caring for the planet's living resources. 6 As more environmental crises develop and compound themselves, man must keep in mind the total web of Iifo as he tries to remedy the problems.

ifany writers believe that mankind can continue to survive if he recognizes the problems in time, and if he devises solutions that mankind as a whole can embrace.

I believe that mar has the poner, the intelligence, and trie imagination to exulacate himseli from the serinus predicament that now confronts him. The necessary first step toward wise action in the future is to obtajn an understanding of the reiationships between man, his natural environment, and his technology.?

Here enters the crucial role of education. In the many suggestions that have been made, and they will be discussed here briefly, education is the necessary ingredient for all of them to be effectively implemented in society.

SLynn White, Jr. suggests that it is the Judaism-Christian mentality that is responsible for man's feelings of dominance. See, "The itistorical Roots of Cur Eological Crisjs," Science, Vol. 155 (Warch 10, 1967), pp. 1203-7.

6 Fraser Darling, "Ecology of Kan," Enericar Scholar, Vol. 25 (hinter, $1955-56$ ), p. 45 .

Tiarrison Scott Brown. The Challenre of Wan's Future: An Inquiry Concerning the Condition of dan juring the Years inat ine Ahead (iei Iork: The Viking Press, 1954), pp. xi-xit. 
Bopulation Control

Population control is a very sensitive subject around the worId, because it infringes on the most intimate of an individual's beliefs and actions. But as overpopulation is one of the most, if not the most critical problein in the world today, the issue of population control noeds to be discussed. Kany suggestions have been made to cut down on the numbers of people in the rorld, or at least to stabilize the growth rate. One such suggestion by the Conarittee on Resources and lian ${ }^{8}$ was for a general policy:

That efforts to limit population incroase in the nation and the world be intensified by whatever ragns are practicable, working toward a goal of zero rate of growth by the end of the century...untinately this implies that the community and society as a whole, ard not only the parents, must have a say about the number of citildren a couple may have. This will require profound modifiestion of cursent attitudes toward paronthoos.

There are less drastio ways that socioty can bo organized to encourage parents to limit the number of children that they want. One suggestion is that tax incentives give tax breaks to those parents who have only two children. Adoption of extra children could be similarily encouraged for parents who want more than two children. A second sufgestion is that family planning services be increased in number and be distributed evenily around the kor.d. In order for family planning services to be increased, however, more money is needed for such organizations as Planned Parenthood, which of ten have had great difficulty surviving financiallyo Also, for such

${ }^{8}$ Comittee on Resources and Man, Resolurces end Yan: A Study and Recommendations (San Francisco: Wo.t. Freeman and Co., 1969), p. 11 . 
services to be just located in poor or minority race areas has created feolings of discrimination and anger on the part of those receiving the services, such as the belief of many Negroes that the whites are out to reduco thoir numbers. The problem of population control is not just that of the disadvantaged, nor of 'the rest of the world' (as Americans often feel). "The population bomb is everybody's baby."

The most extreme suggestion is for government regulation of the number of children that a couple may have, giving permission to couples, and terminating pregnancies in families with two children. Although strongly urged by some, and feared by most, this suggestion gravely conflicts with the values of freedom held by most people.

"Continuing growth in man's numbers and in his consumption of the earth's resources has been a cornerstone of Western man's belief in progress. Now it is called into question. 99 This calls for re-education to overcone previous values and beliefs. Aria a broader scale is critical, as Borgstrom coments about efforts to resolve the population problem: ${ }^{10}$

Most of our efforts to master the present population increase have been on a Iilliputian scale. We noed a broader program of general education and a mobilization of the world's brairimpower to facilitate a clear understanding of these issugs and their true dimensions.

Very much related to population control is the suggestion

${ }^{9}$ Charlton Ogburn, Jx., "Why the Global Income Gap Grows hilder," Population Eulletin, Vol. XXVI, No. 2 (June, 1970), p. 5.

10 Goorg Borgstrom, The Hungry Planet, p. xiv. 
that the medical profession and religious institutions take a stronger stance on the whole issue of population control. The American Kedical Association has refused to take any strong stand on such issues as birth control, abortion, and sterilization. Patients desiring infomation and services have often found doctors unwilling to help. At least doctors ought to refer a patient to another doctor tho does support these measures if he himself is opposed.

The Church has often been criticjzed recently for not boing relevant to the needs of society. The ided that man is part of a great ecosystem that should be preserved and cherished might come closer to boing an acceptable substitute for the religious beliefs that many men have discarded. Education ained at changing attitudes of medical and religious personnel is needed now.

Political Action

Those actively concemed with the environmental crisis have made the suggestion that more legislators concerned with the environment and more legislation are needed. Many believe with the Bhrlichs that the laws of our free enterprise system are failing to meet the needs of everyone as long as they pexmit unrestricted reproduction and pollution. ${ }^{11}$ But more laws may not be enough. Dubos $^{12}$ is critical of the government when it does work on environ-

${ }^{11}$ Paul R. Enrlich and Anne H. Ehrlich, Population, Resources, Environmant (San Francisco: W.il. Ereeman and Co.s 1970), p. 268.

13 Rene Jules Dubos, So Humar An Aminal Vivew York: Scribner, 1968), pp. 229-30. 
mental improvement. He says that most of the measures they undertake are palliative and at best short-sightod adaptive responses to acute crises, expressions of fear or panic rather than of constructive thought. He points to the progress of the Great and Beautiful Society as examples. He feels they are a hodge-podge collection of measures hastily formulated to correct a few glaring defects in cities and in the country, but they do not get at the basis of the problem. Ho also suggests, urifortunately, that Congress will only move then an environmental catastropho frightens the public sufficiently to force Congress into action.

Many suggest that the quality of laws ultimately raflects the concexn of the citizenry. For example, the Rienows strongly support the view that public complacency ovor the enviromental problems noeds to be changed and they particularly blame the attitude that science and technology will solve all of our problems. They see this "rivth of scientific infallibility" as a convenient way for the public to avold civic responsibility in doing something about the problems. 13 Tho public noeds holp to understand and to judge the moral rightress and cultural worth of tho courso that scientists tell us to take. ${ }^{14}$ since environmental problems are essentially social problems, the probloms belong to everyone,

13 Rienow and Rienow, woment in the Sur. p. 199.

14h.B. vanLoom, "Population, Space, and Hunan Culture," Law and Contemoorary Probiems, Vol. 25 (Sumer, 1960), p. 405. 
and as Deles suns up when speaking of pollution;" 15 "In the end it is you and $I$ who are going to olect the politiclans who are going to decide how much poilution we are going to have, what sort of pollution it is going to be, and where we are gaing to have it."

Proposals abound. Enrlich has suggested a Departwent of Eopulation and Environment ${ }^{16}$ with power to force needed changes. Strict controls would be enforced by this department in areas such as pesticides, quantity of children per family, and onviromontal quality. It would also aid Congress in developing legislation related to population and environment, and to inform the public of the needs of such legislation. In virtually all of these cases, education is a critical component. Education is noeded to give the public the understanding of the emironmental problems, as frell as to incite them to action to bring pressure upon the logislators to legislate needed changos.

\section{Economic Action}

Mang blame the attitudes of men for the environmental crisis. Since the founding of the United States, the attitude of Americans has been to consume, to grow, and to progross. They moved across the country, consuming as they went and not replacing the wealth of natural resources that they used. At present, say the crisis

15J.H. Dales, Pollution, Property, and Prices, An Essay in Policy liaking and Esonomics (Toronto: University of Toronto Pross, 1968). p. 104 .

16 paul R. Fhrlich. The Pooulation Bornb (New York: Ballantine Books, 1968), pp. 138-9. 
thinkers, this has caught up with man.

Air pollution, like water pollution and all the other exarples of our deteriorating conditions of living, is a by-product of too many poople with too much push in the direction of econonie progress and not enough in the direction of social progress.17

The result of "growthmania" in the United States has been an overconsumption of resources and materials. The United States with six percent of the world's population consumes over 50 percent of its resources, and that figure is expected to reach 80 percent by the year 1980.18

Such consumption produces a tremendous amount of solid wastes which are disposed of as pollution into the air, waters, or landscape, from industries producing goods for the American consumer. ${ }^{19}$

Each year in the United States we must dispose of some 55 billion ens, 26 billion bottles cad jass, 65 billion metal and plastic bottie caps, and moro than half a biliton dollars of other packaging materials. Soven million automobiles are junked each year, and the amount of urban solid wastes (trash and garbage) collected amually is approximately 150 million tons.

Industries have received much criticism and blame for the condition of our deteriorating environment, though to a degres the industries will respond to what the American public denands, and there has boen little solid demand for changes.

While proposals abound, many call for major changes in attitudes and values, a.s Ezra Mishan: ${ }^{20}$

${ }^{17}$ Rienow and Rienow, Eoment in the Sun, p. 118.

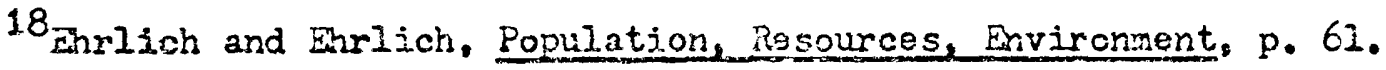
19 Ioid, p. 128.

20 Eara J. Mishan, The Costs of Ejcunomic Growth (Ned York:

Frederick A, Praeger, 1967), p. 274 . 
... If men aro concerned prinarily with huran welfars, and not primarily with productivity concesved as a good in itself, they should reject oconomic growth as a prior ain of policy in favcr of a poljey of seeking to apply more selectivo criteria of wolfare. Such a policy would involve (I)legislation to spearhead the attack on much of our post-war blight; and (2)a substantial diversion of investible resources from industry to the task of replanning our town and cities a- in general, to direct our national resources and our ingenuity to recreating an environnent that will gratify and irspire men.

The jdeas and attitudes that lead to "growtimania" can no longer be tolerated in today's world. Not only must the United States change its attitudes towards economic progress, but also must encourage the underdeveloped countries who are trying to copy the United States'industrial progress, to consider and value the dr total environment as they modernize. Air and vater pollution know no political boundaries, so economic growth has to be consiaderea iron the viowpoint or anternational consequences.

Edueation is needed to convince Americans and any other people with high economic growth that a change in life style is needed. It is in many ways the high consumption by peoples that has created our environmental erisis and this trend needs to bo reversed. "There is a price for progress."

Tre Role of Education

Unfortunately, educational programis have not been successful. 22

21 a coment by Robert C. Cook, quoted in Monent in the Sun, by Rienow and Rienow, p. 205.

22. George Harrar, "Beyond Survival," in The Next Ninety Years, Proceedings of a Conference Held at the California Institute of Technology, Narch, 1967 (Pasadona, California: California Institute of Tecinology, 1967), p. 67. 
Today all the training and oducation he have provided for ourselves have failed to give us an juareness of what wo, either by our passivity or by our actions, are doing to our environment and, ultimately, to ousselves.

Eaucational progxans have not been providing the public with the kind of education that will help them avaluate the choices that are, or will be, available to them, to prepare them to understand and make decisions relating to tho environmental crisis. Auerbach and Flieger, for example, dispute the viow that sinee there is an increased concern among the public about air pollution, the educational needs are being mot: 23

This is simply not trie. Nor is the corollary true that the need for public information and education programs is already being adequately met, the need for such programs is greater now than evor beforo and, will inevitably be even greater in years to come.

There are many ways of arucating peonle. Gurriculum development for schools is one way of eccomplisining this goal. Inproved curricula aro important nays to do something about tho environmental crisis. Curricula focusing on the environmental crisis may also help the schools. One of the biggest complaints of American high school students tocay is that high school education is not relevant to the noeds of students. Studonts have becomo disenchanted studying subjects which they feel will have no bearing on their Iffe, no meaning for their work, or no usefuiness for them as they face the problems of society. There inay be no more reivenant subject to be studied than our environment and our

23Irvin I. Auerbach and Konneth Flieger, "The Importance of Public Education in fiir Pollution Control," Journal of tho Air Pollution Control. Asseciation, Vol. 27 . No. 2 (February. 1967), p. 102. 
survival as a hunan raco.

Not only does the environmental crists make such curricula very relevant, but curricula developed on this crisis could engage students in the kinds of problems that they will have to come to grips with as they become adults .. the numioer of children they will have, the kind of 1 ife style they want fos thamselves and the effect that this life style will have on the quality of the environwent, their role with respect to organizations dedicated to preserving the enviroment (wildlife and wilderness organizations), and their own role as citizens: rill they write letters to Congressmen, consume less, and recycle as individuals; or will they romain apathotic citizens?

Some view ecology as possibiy providing an organizing frame. work for locustang the entire school curriculum: 24

Ecolosy, more as a mode of analyzing and viering our physical and biological frorld than as a precise experimental science, could, in the $1970^{\prime} \mathrm{s}$, beccme a fulcmu of school curricula around wich many other disciplines would pivot. Biology. geography (greatly enlivened by infusions of economics), derography, geology, agronomy, anthropolozy (with much greater ermohasis on natural history and the changing relationships of man to his environment, how he has treated it and hoy it has treated him) and other disciplines can al. contribute to a deeper understanding of our world ecosystem.

Our educational establishment, from elomentary school through the post-graduato college years, can perform no more useful sarvico than to illuminate the principles of human survival and to dedicato itself to preserving and enhancing the quality and diversity of life.

24 Rufus E. Miles, Jx., ed., "Whose Baby Is the Population Problem?" Population Eulietin, Vol. XVI, No. I (February, 1970). p. 31 . 
Curricula developed to meet the eriterion of relevance and to help resolve the environmental crisis would fit easily into the modern trend toward problem oriented, multi-diseiplinary approaches. Too Iong the schools have been strictly discipline oriented. Today's world problens cannot be solved just by sociology, or psychology. or economics. The problems need the thoughts and rork of all the disciplines, practitioners and scholars alike. Creating a multidisciplinary approach in the public high schools will be no easy task. Neither will the creation of new curricula, whether in the form of a separate course, or as materials on the key concepts for 211 the standard subjects, be easy. Curricula schedules are already crowded with subjects that some peoplo foel are nocessary. Environmental education will undoubtedly involve attitudes and values, and in the past, schools have tended to shy aray from any conflicts of this nature. Across the country some "man-in-environrent," or "ecological crisis" kinds of courses have been developed by interested and concerned teachers. But this curriculum development has boen on an individual basis, usually with the teacher focusing only on what he knew about, had available, or felt was important. The efforts, to say the least, have been isolated and disjointed. But the costs of failure, and the rewards of success, are high: 25

Mang of the benefits will be discouragingly intangible a blue sky insteac of a gray one, trees and green fiolds instead of barren hillsides, bird songs instoad of a silent

25 Robext Morison, "Education for Enviromental Concerns," Daedalus (Fall, 1967), pp. 1221-2. 
spring, clean streets, rel].proportioned facades, and quiet walks instead of ugliness, traffic jams, and noise. Tho educational system for tomorrow must not only make it clear how these presumable goals can be achieved but why they aro worth achieving.

There is, of course, no guaranteo that increased "population" or "environmental" awareness induced by courses or curricula will lead to attitude changes, or different life styles, or to concerted involvement, but there is some evidence that attitude change is related to awareness. It certainly is worth trying through curriculum in the schools to create an ecological awareness, coneern, and involvement in 0.1 students. They, afterall, will someday become adults charged with the responsibility of continuing a quality environment for the next generation.

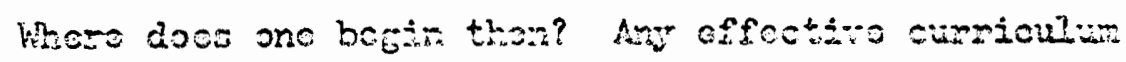

development needs data on where students are in their thinking. for the future of the envircment will be largely what they chose it to be, and these choices will, in turn, depend in large part on what they think life itself ought to be. 26 It was to explore this question -- the present viow of students toward the environmental crisis - that this study was undertaken.

Ripley and Buechner's article ${ }^{27}$ served as a point of doparture for this exploratory research project. They stated that

26 Ibid., p. 1220. For further suppost soe "Population Education - Evolution or Revolution," Population Eulletin. Vol. XXVI, No. 3 (no date given), $\mathrm{pp} .4$ and 20.

27 S.D. Ripley and Belmut K. Buechner, "Reosystem Science As A Point of Syrthesis," Daedalus (Fall, 1967), pp. 1192-9. 
while the most critical problem facing humanity today is an ecological one of relating husan societies hamoniously to their environnents, the task of focusing knowledge on contemporary world problems in an ecological context seemed overwhelming. They then presented a two-dimensional conceptual mocal, based on levels of integration and points of view, as an aid in orienting knowiedge toward the environmental crisis.

However, the critical fdea that Ripley and Buechner contributed to this study was the notion of a conceptual environment: 28

Man's image of the world in which he lives and his understanding of man's place in the universe are critical in achieving ecological homeostatis. Science can contribute basic facts and ideas about ecosystems. But man's concerns and values also determine the behavior of

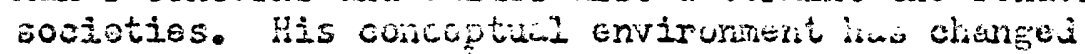
through time, a transiomation expressed in literature, poetry, music, architecture, and modifications of the landscape. The naturial scjentist will nost probably have less influence in the evolution of a conceptual environment relevant to today's ecological crisis than the humanist. Han's conceptual environment, not science, will determine the future of humanity.

They see the humanist having the responsibility of developing our understanding of values with rolevance to the central ecological crises of today. We should study the whole ecosystem of humansociety-plus-environment and the interrelationships between these systems on a global basis, even though we can never achieve a total understanding of d.t. They feel that their two-dimersional conceptual model does provide an approach through winch inter-

$$
28 \text { ibids, p. } 1196 .
$$


disciplinary efforts can bo organized to evolve unifying principles and concepts leading to a vetier understanding of man's place in the universe. Their model represents a point of synthesis of research and education to focus them on the contemporary problems of adapting human societios hamoniousiy to their environments. As mentioned earlier the task of achioving an ecological orientation on the part of the population cen come through curriculum development in educetion. The empirical study that follows is a beginning attempt to discover what the ecological awareness and concerns of some high school students -- their conceptual environment - are. By doing this, one hopefuliy can point directions for the needed curriculum derelopment. 
CHAPTER III

\section{DESIGN OF TRE STUDY}

\section{Introdustinn}

An individua's relationship to the environmental crisis has several possible levels. Many peoplo are merely aware of one or mare aspects of tho enviromental erisis; they have some knowledge of the problens. Others not only know about various aspects of the crisis, thoy have a value gystem which enables them to judze certain enyironmental situations as exises; in short. they not only are aware of the problems. they are concerned about then. Finaly, there are those who are not oniy aware and coneerned, they are actively involved in trying to deal with the enviromental cxisis. The purpose of this exploratory study, then, has to find out how aware, concerned, and involved some high school students were with the environ mertal crisis.

Students were interviewed from two suburban high schools in Portiand, Oregon. Interviened at each high school were key informants, either juniors or seniors who were taking an environinental crisis course; a random sample of juniors who were not; and all teachers of the enviromental crisis courses. A total of 98 students and 5 teachers were intexviewed during the spring of 1971. 
Instruments Used

The interview was the method lised to obtain information from both students and teachers. It consisted of two parts for the students: a group of pictures representing ecological problems to be ranked in order of ecological importance and discussed, and general questions.

Eight pictures were selected from magarines to represent various ecological problems, as air pollution, overpopulation, noise pollution, and man's relationship to nature, though each was subject to a variety of interpretations. All wero numbered and presented to the students. The pictures wors used at the beginning of the interview. Students were told to rank these pictures in ordor of ecological inportance, the intorpretation of ecological iroportance being left to the student. There were very few questions by the students associated with this procedure, and it created ar. interest in the student right at the beginning of the interview. After the students had placed the pictures in the order that they wanted, the order was recorded, and each picture was discussed.

The idea of using ecological pictures came from The Focused Interview. In it the authors stress the importance of something that constantly san be referred back to in the interview discussion, as a movie, a book, or slides. Using the ecological pictures allowed the students to see a problem and discuss it without having to rely on memory. For many who had never been interviewed

${ }^{1}$ Robert K. Merton, Marjorio Fiske, and Patricia L. Kendall, The Focused Interview (Glencos, Illinots: The Froe Press, 1956). 
bofore, this was inportant as they were a bit nervous when they began to taik.

Questions for the direct interview were writien in three categories -- for example:

Awareness: What do you consider to be the throe most important ecological problens in the world?

Concern: Do you think man's survival is endangered in the world? in the Pacific Northwest?

Involvement: Have you ever tried to do anything about the ecological problems at school? outside of school?

After the completion of the picture ranking and the interview, each student was asked to fill out a questionnaire covering sccio-economic information and ecological interests of the student. The student was told that this information would be held in strict confidence.

The entire interview was tape recorded, the tape recorder being placed in the middle of the table. Each student was asked if he minded being taped, and with the excoption of one student. all agreed to be taped. Each student was al so told the purpose of this study, and the affiliation with Portiand State University, at the beginning of the interview. The interviews lasted from 20 to 45 minutes.

The teachers and student teachors of the environmental crisis courses were also interviewed and tapod. They were asked about the origination and development of the orviromentai crisis course, their major emphasis in toaching the course, what the 
content and activities were for the course, wither they had seen a change in the awareness, concern, and snvolvoment of the students they taught in the course, and what wore their major ecological concerns and involvements.

\section{Pilot Testing}

Originally there were just a background qusstionnaire and a interview. These rore pilot testod on five students at one high school reconmended by teachors as key informants bocause of their interest and involvoment in ecological activities. No pictures were used in this initial set of interviows. The questions on the interview were modified as a result of the pilot test for the actual interviews. Some modifications were also made on the gupstionnatre to eliminato onme confustng and irrolevant cuestions.

The original intent of this study was to use only key informants. 2 These students, it was felt, could transmit the greatest amount of information about their om, as well as other students' awareness, concern, and involvements with the environmental crisis. A key infomant should also be motivated to share information with the interviewer, ard the selection of the high school students was made on this premise.

However, the interviowing of the equivalent of key infarmants during the pilot testing uncovered a critical problem. When the

2Kurt W. Back, "Tho Well-Informed Informarst," in Huran Organization Pesearch, ed. by Richard N. Asians and Jack J. Preiss (Homewood, IIIinois: The Dorsey Press, 1960), p. 181. 
Informants were asked to talk about the activities of other students, they could not even give names of other students who were or were not ecologically involved, let alene what these students believed or did. Some would say that they knew of a few others tho were involved, but they did not know their names or much about them. This request to talk about other involved students was repeated during the regular interviews to seo if the pilot test phenomenon was accidental, and it was not. Students in these schools just did not $s e \mathrm{~cm}$ to know tho names or activities of many of the students in their classes, raiging probloms for any key informant methodology in studies involving high school students.

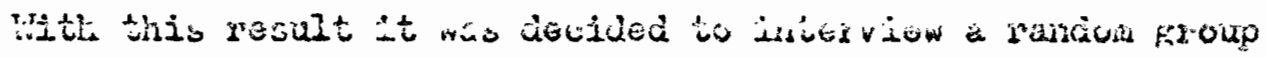
of students in addition to informants from the ecology courses. The difference in responses between the informants and the ranitom group of students was large, so it was docided to proceed with both groups of students, informant and random, in the regular interviews.

The "picture test" was also developed and pilot tested because initial stralght incerviews were difficult for a nuraber of students. Twenty pictures were used, and initially each stuient was asked to categorize or ariange the pictures into groups according to which ecological problems seemed to fit together. Although the students experienced little difficulty in grouping the pjetures, the process was timemconsuring, and it was discovered that more information could be obtained in less time by just 
having the students rank the pictures in order of ecological importance. It was decided to follow this pattern in the final study.

Study Settines In The Portland Area

Through telephone interviews with all the curriculum viceprincipals in the Portland Public School Sysiem, and most suburbart systems, it was found that there were only threo high schools with ecology courses, Aloha in Beaverton. Reynolds, and one high school in Portland, whose class was small and comprised mostly of seniors. Aloha's course ran for a full year, while Reynolds went for a semoster. Other schools in the Portland aroa had ocology clubs, or taught ocological problems in with thoir science and social studies currioula.

Since this study took place at the end of the school year. it was more difficult to get in touch with studsnts who were involved in ecology clubs, most of wich had disbended for the year. Interviewing students in courses also elloved students to be taken out of these classes instead of taking them from other subjects, a procedure not very appreciated by other subject matter teachers when the school year is closing. And the class with seniors eliminated a number of days of fossible interviewing, as seniors are graduated earlier than the end of the school year for other students.

Since the major concern of this study was curriculum, and given the practical problems, the decision was made to interview 
as informants only those who were involved in the environmental crisis courses at Aloha and Reynolds.

Although there were no socio-economic data available on either school, an intuitive judgment was that both appeared similar. Both schools attract a wide economic range of students from suburban and rural settings. Both environmental, courses had been in operation for the same length of time, one year, and both courses had more thar one teacher teaching them. The responses of the random sample from both schools, then, ought to be sinilar; the responses of the informants night vary, according to the major emphasis of the curriculum in each of the two courses.

The generalizability of the findings should be restricted to those schools with similar characteristics as described here. No intent is made to generalize the findings to urban settings where the responses might be completely different. Any attempt to carry out this study in some urban schools and to compare the data will have to await further studies.

\section{Sources of Data}

The key informants were recomnerided by the teachers of the environmental crisis courses. In both schools where the study was undertaken, a group of teachers worked together, so that the students recommended usually were recommended by more than one teacher. No number was specifically requested. The teachers listed all of those students they felt met the criteria of a key informant. There was an attempt, however, to arrive at a balance 
between boys and girls. At poynolds all infomants recomended were interviewed, a total of 24. At Aloha, of tine 15 recommended informants, 12 wero interviowed.

Through the use of a table of ranciom numbers a random sample of those juniors from each school who had not taken the course was chosen. Since most of the students in the courses were juniors, it was decided to restrict the rendom sample interviews to juniors to save time and to make comparisons more easy between random students and informants. At Reynolds there were 260 juniors, one-half of whom had taken tho "Nan-in-Enviromment" course. A 20 percent randon sample was drawn from the list of approrimately 125 juniors who had not taken the course, and all twenty-four were

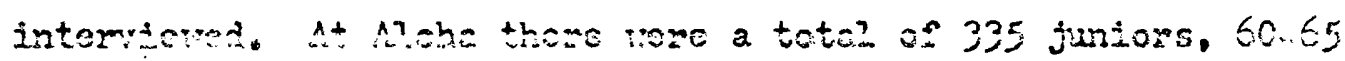
of whom were taking the "Ehvironmental Crisis" course. A 10 percent randow sample was drawn in the same manner as Reynolds, and a total of 35 students were interviewed. Cniy one girl, although contacted, never came for the intorview. A combined total of 85 were intorviewed, 26 informants and 59 random.

As much as possible, students were interviewed during their social studies courses to prevent cutting into other courses, or were interviowed during thoir froo periods. At Reynolds a study area adjacent to the social studies resourco center uas used for intorviewing students, wilo at AJoha the Teachors' Professional Library was used. 
Tabulation of Data

All of the tapes wer transcribed almost vorbatim in order to get the most accurate arpressions of the students. In transcribing the tapos indications were also made as to whether the student responded spontaneously to a question, or whether he had to be prodded.

A content analysis was made of the responses to the questions in the interview, as well as of the responses to each of the ecological pictures. These date were then coded, and along with information from the questionnaires, key punchod, and statistically analyzed. The chi-square statistic was used in the analysis of the data, using the categories of students, informant and random. as tho control variables. Furthor analysss of subgroups within random or informant were not conducted because of the small sample size, particularly of the informants.

The results of the analysis and the interpretations are found in the following chapter. 
CHAPTER NV

FINDINGS: DATA AND INTERPRETATION

An exploratory research effort inevitably yields data which can be used to address a huge variety of questions. Given that curriculum development was identifiod as one way of infuencing the necessary change in attitudes toward ecological problems, the overall intent of this study was to generate data to support curriculum development efforts in the area of human ecology.

There are three major gusstions related to curriculum which these hate can be usod to ardenan:

1. Did the two different courses in the two differont schools have a different impact on the studonts who took the coursesi

2. Assuming that most ecology courses will be elective, or voluntary, is thare a significant difference botween the background characteristics of students who chose to take ecology courses (the informants in this study) compared to those who do no (the random sample)?

3. Is there a significant differenco botween the infornants and the random students in their ecology knowledge or awareness, in their values or their degree of concern, and in their activities or involvement in ecology?

The first question, when related to information about the courses, should suggest conclusions about the impact of the courses, and possibly what seems to hava contributed most to the impact. The last two questions will suggest the rature of the population to 
which ecology courses will naturally appeal, for the value that that has to enable curriculum developers to build on these characteristics. The data will also challenge developers to design curricula to reach students who do not choose ecology courses.

There are several obvious conditions of this study which make some conclusions diffieult to draw. Since data were collected only after the courses were noarly over, it is difficult in some cases to tell for certain whether the differences between random students and informants can be accounted for by the effects of the courses or by the process of selecting the course in the first place. Also, in spite of the comparatively large number of interviews for a singlemperson study, the sample is still small for a number of smb-analyses winch might proxe intomesting. Nevantheless. in addition to the development of an effective methodology for investigating student ecology ideas, the stady should suggest numerous topics for more careful scrutiny.

In considering the three questions, information from all three components of the survey has been used -n the background information sheet mich each student filled cut, the questiont asked in the structured interview, and the incormation obtained from the student's discussion of the ecological pictures.

\section{THE INPACT OF THE DVIROMRENTAT CRISIS COUPSLS} ON THE INFORUNWTS AT RENTOLDS AND ALOHA

This section will attempt to determine whether the courses did indeed have an impact on the students in them. First, as 
these environrental crisis courses were the only two of this nature offered in the Fortland area, it would be worthwhile to mention how they came into being and how long they had been in existence. The teachers' major emphasis in teaching the courses will also be discussed. Then solected interview questions will be analyzed to dotermine if the emphasis in the two different courses affected the responses (concerns, interests) of the informants to these questions: What are the specific reasons why an ecological crisis exists in the world? Why is man's survival endangered? What are the three most important ecological problems in the world? Does the United States have a population problem? Lastly, whether the courses had an impact on the ecological involvement of the informants in school. and ontiside of school will be analyzed.

The "Wan-in-Environmont" course at Reynolds and the "Environmental Crisis" course at Aloha both began operation in the fall of 1970. Both came into being under similar circumstances -- curriculum reform in each of the respective schools. After each of the proposals for a new course had gone through school channels, it was offered as a choice to the students, along with several cther choices. In both schools the ervironmental crisis course was extremely popular with the students, and so both began. The teachers in both schools were involved in writing the proposal for the new course, as each! possessed a real irterest in environmental problems. At Reynolds the course was offerad only through the 
social studies teachers, and lasted one semester. At Aloha the course was beginning attemt to be interdisciplinary, with a science and a social studies teacher responsible for the course. It lasted the whole school year.

There was a difforonce in the objectives that the teachers had for their courses at the two schools. At Reymolds the major focus of the "lfan-in- Bhvironment" course wes to change attitudes. That "by becoming aware of the problems and exposed to some of the solutions, a student would in turn change his attitudes toward the environment, and maybe even see some solutions," was the major emphasis of one of the Reynolds teachers. The second teacher felt that the antwer to the existing environmental problems is a sound relationship between peoplo, a more extensive attitude change.

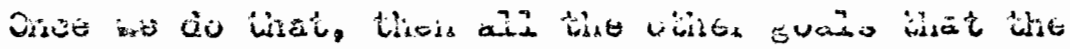
citizens of this country have established for thomselves, and the ones that the undercieveloped nations want to acquire, really ceass to be meaningful - the money, the acquisizion of things. If we all really just desire a botter relationship and understanding between each othor, it seems to me that the ervironment by that nature will clean up.

As the major emphasis was on honest relationships among people and related attitude changes, neither teacher stressed content that much. They did briefly discuss eight areas of onvironmental concem, fren which students chose areas of interest for individual research projects: air and water pollution, solid wastes, overpcpulation, nolso pollution, food, urbanization, transportation, and human relations.

The major emphasis of the teachers at Aioha was different from 
the emphasis at Reynolds. As one of the Aloha teachers commented:

Man is part of the biosphere - he isn't above it, apart fran all living things. Trerefore, he is subject to the samo laws as governs nature.

Man is threatening the biosphere and that is the reason why he must be coped with. The peril is extremely great. It is not in the distance. The ecoiogical web, winich was so complex, is threatensd already. If man is a part of all living things, he can't teminate a species. There's no basis for hin to take orer the biosphere, to be the only species. There is no grounds for that kind of behavior.

You'd have to add that there is a possibility to do something. You can do something, and hopefully you must.

In discussing the peril, the problems of overpopulation were particularly stressed. Over 60 percent of the class time at Aloha was devoted to outside speakers and agencies - poople concerned abolit particular topies. Since one of the two teachers was a science toacher. students did lehomatary experiment = that doalt with ocological problems, such as measuring the biodogradableness of different soaps in water. The last quarter of the year the students rexe involyed in either an action project or a research project of their own choosing. During the year much emphasis in all the activities in the course was put on what the students individually could do.

How much impact did the courses have on the informants? The data rill yield some answers to this question, using selected, relevant questions asked of the informants. 1

Whon the fieynolds infornants mentioned specific problems to support their contention that an ocological crisis does oxist in

${ }^{1}$ See Appendices for the Student Zackground Information Sheet, Interview Guido, Teachor Intorview Guido, and Variable Dictionary. 
the world, 36 percent of them responded that the problems of awareness, education, of atiditudes were responsible for the crisis.

I think, since taking the course, that things aro a little more serious. A lot of poople don't that Iive talked to on my own. The problem is education.

The stubborness of people who keep dumping into the rivers and who know, and who have been warned. They keep doing it. They'd save a lot more if they'd put money into cleaning it up than if they keop on polluting. It gets worse and vorso ... the same goes for the air.

Again, when the Reynolds informants gave reasons why man's survival is endangered, they mentioned 57 percent of the time that it depenas on man's attitudes, awareness, and concern as to whether man will find solutions to the problems of the enviroment.

Because of attitudes. People around here are wrappod up in their om things. He'll go along obljuinus to what's hopponine. destroying himself. tii it ilappens.

I'm pessimistic to the point where people will fool around and wait until there is a crisis before they do something. Right now everybody's too worried about making money, getting what they want. To do anything about this problem, they will have to sacrifice, and they're not going to do it until they have to.

From the responses to these two questions, it is a reasonable conclusion that the course did influence the Reymolds inf'ormants. It is interesting to note that when tho Rejmolds informants were asked the major emphasis of their "isan-in-Environment" course, only 14 percent of them responded that people's attitudes need changing about the crisis. 64 percent of them, however, responded that they felt that the major emphasis of their course was 
knowledge - - being made aware of what the problems are in the environment, and then doing something about them. The major emphasis of the course, then, changing attitudes and awareress of people, the Reynolds informants related not only to others, but to thomselves as we11. Tho "Kan-in-Environinent" course at Reynolds did influence those who took it.

There was more of a definite interest or concern with one topic or problem at Aloha than there was at Reynolds. In Table I the responses from the informants in both schools are compared. The question asked them to list the three most important ecological problems in the world.

As can be seen from this table the major interest among the infomarts at Aloha is the problem of population. Other questions supported this finding. When asked their major interest in environmental issues, 75 percent of the Aloha informants mentioned population. Not only were they interested in population, but they also saw it as the major cause of the environmental crisis in tho world and in the Pacific Northwest. 58 percent of the Aloha informants felt that population was an environmental problem because it was the crux of $2 i 1$ the other problems. "Overpopulation is the main problem. Without it we wouldn't have the trouble of pollution. There's so many people, so unless we have less there's nothing we can do."

When asked if the United States had a population problem the informants at Aloha responded, yes, overwinelmingly (83 percent). 
And when asked if they would be willing to limit their families to two, 100 percent said that they would.

\section{TABLE I}

THRES MOST IMFORTANI ECOLOGICAL PRORLETS IN THE WORLD ACCORDING TO INFORMANTS

\begin{tabular}{|c|c|c|}
\hline & Reymolas & Aloha \\
\hline $\begin{array}{l}\text { Population, Air Follution, } \\
\text { Water Pollution }\end{array}$ & $\begin{array}{r}298 \\
4 \\
\end{array}$ & $.42 \%$ \\
\hline $\begin{array}{l}\text { Population, Scarcity, } \\
\text { Pollution }\end{array}$ & $21 \%$ & $\begin{array}{l}0.8 \\
0\end{array}$ \\
\hline $\begin{array}{l}\text { Population, Pollution, } \\
\text { Other: }\end{array}$ & $7 \%$ & 2 \\
\hline $\begin{array}{l}\text { Pollution and Other } \\
\text { Rlesponses for Problems }\end{array}$ & 298 & 8 \\
\hline $\begin{array}{l}\text { Ropulation as the Crux of } \\
\text { All the other Problems }\end{array}$ & $0 \%$ & $\begin{array}{r}338 \\
4\end{array}$ \\
\hline Other Rosponses & $24 \%$ & 0 \\
\hline
\end{tabular}

CELL PERCENTS BASED ON COLUN SUMS

CHI-SQUARE STATISTIC $=11.1566$ WITH 5 DEGREES OF FREEDOM (SIGNIFICANT AT 0.050 LEVEL)

There may be some explahations why the problems of overpopulation were of so much concern to the Aloha informants. 
TABLE II

HOW INFORNANTSS BECAME ECOLOGICAJIY INVOLVED

\begin{tabular}{|c|c|c|}
\hline & Reynolds & Aloha \\
\hline $\begin{array}{l}\text { Trrough another person ox } \\
\text { friend }\end{array}$ & $\begin{array}{r}14 \% \\
2\end{array}$ & $\begin{array}{r}0 \% \\
0\end{array}$ \\
\hline $\begin{array}{l}\text { Through the course and/or } \\
\text { teachers }\end{array}$ & $\begin{array}{r}29 \% \\
4\end{array}$ & $\begin{array}{r}67 \% \\
8\end{array}$ \\
\hline Through parents & $\begin{array}{r}14 \% \\
2\end{array}$ & $\begin{array}{l}8 z \\
1\end{array}$ \\
\hline Through the modia & $\begin{array}{r}7 \% \\
2\end{array}$ & $\begin{array}{r}0,8 \\
0\end{array}$ \\
\hline Othaz says & $\begin{array}{r}14 \% \\
2\end{array}$ & $\begin{array}{r}25 \% \\
3\end{array}$ \\
\hline Not applicable & $\begin{array}{r}22 \% \\
3\end{array}$ & $\begin{array}{r}0 \% \\
0\end{array}$ \\
\hline
\end{tabular}

CIII PERCONLS BASED ON COLUNAN SUISS

CYI-SQUARE STATISTIC $=4.834$ WITH \& DEGREES OF FREDDOM

(NOT SIGNIFICANT AT 0,100 LEVEL)

The difference in the kind of school ecological involverient between the two groups of infornants is illustrated in Table III. 
TABLE III.

ECOLOGICAL INVOLVEMHNT OF INFORMANTS IN SCHCOL

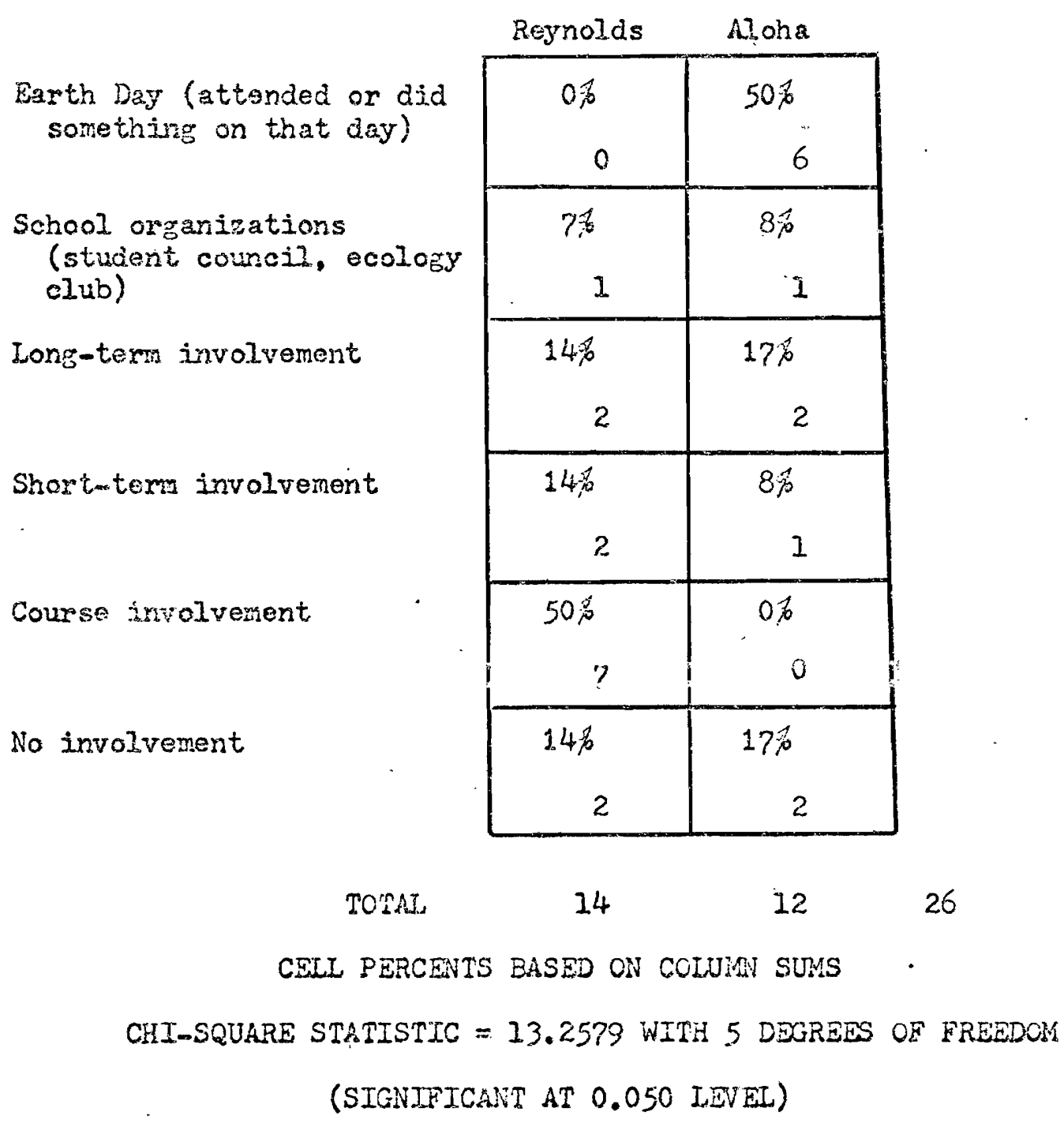

An example of long-tem personal involvement is the informant who initiated a glass drive for the school, collected glass all year, and then took it to the Cwens-Illinojs Company. Those involved in short-tern activities would do such things as periodically clean up the litter in the school yard or the cafetaria on their 
om. Particularly for Reynolds informants, the course offered them the only opportuntiy of coing something with certain environmental: issues. One example of this is the experience that some of the Reynolds students had of goling to Bell Telephone Company to talk to the employees about the envixonmental problems.

The Reynolds informanis, though, ware significantly less involved outside of school than were the Aloha infornants, as seen in Table IV.

TABLE IV

ECOLOGICAL INVOLVEACNT OF INFORMANTS OUTSIDE OF SCHOOL

\begin{tabular}{|c|c|c|}
\hline i & Reynolds & Aloha \\
\hline $\begin{array}{l}\text { Very involved and tries to } \\
\text { convince others to be. }\end{array}$ & $\begin{array}{l}7 \% \\
1\end{array}$ & $\begin{array}{r}338 \\
\quad 4\end{array}$ \\
\hline Very involved & 2 & 0 \\
\hline $\begin{array}{l}\text { Partially involved and tries } \\
\text { to comvince others to be }\end{array}$ & $\begin{array}{r}29 \% \\
4 \\
\end{array}$ & $50 \%$ \\
\hline Partially involved & 298 & $27 \%$ \\
\hline Ljttle or no involvement & $21 \%$ & $0 \%$ \\
\hline
\end{tabular}

TOTAZ $\quad 14 \quad 22 \quad 26$

CELL, PERCERTS BASED ON COLUMA SUMS

CHI-SQUARE STATISTIC $=7.7587$ WITH 4 DEAREES OF FREEDOM

(SIGNIRICANS AT 0.100 LENEL) 
The informants who vere very involved and who tried to convince others to be did such things as: attended conferences on their own, attended hearings and legislature neotings, became members of oxganizations such as Zero Population Growth, recycled all materials (cans, glass, paper), and talked a great deal. to their parents, friends, or exployers about environmental problems and ways to help resolve then. Bartial involvement meant that students rscycled, conserved materials, and participated in other activities of this nature. These students were not as extensively involved in organizations and projects as were the vary involved students.

It is difficult to determine the reasons for the lesser inyolvement of the Reynolds informants outsicie of school. Cne explanation might be that the many guest sperkers from various organizations that spoke at Aloha provided information about 'action: projects. The students at Aloha then would have moro opportunity to join such organizations or at least gathor information on how to get involved. Also, some of the speakers provided the incentive for projoct topics for various students. For examplo, after a Tri-liet representative spoke, tro informants became involved in conducting a survey in the Aloha area about their community feelings of riding mass transit. This may explain, too, why 100 percent of the Aloha informants rould support mass transit, while only 27 percent of the Rejnolds informants would. Trese are only suggestions for reasons, but it certainly seems that the courses 
did influence the ecologleal involvenent of informants.

Sumary: The Impact of the Bhyironmental Crisis Courses On ine Informants it Reynoles And Aloha

Did the environmental crisis coumses influence the students' responses and their involvement in ecological activities? The data indicate that they did. The Reynolds informants, with inss stress put on specific content in their course, felt that the problems of changing awareness, attitudes, and education were very important if the environmental crisis was to be resolved. The Aloha informants, however, were more interested and concerned about the problens of overpopulation, because of the emphasis that had been put on it in their course.

The informants responded that the courses also influenced their involvement in ecological activities in school and outside of school. Many opportunities were presented to the Reynolds informants in their course, and it is through their course that most of their involvement in enviromental issues in school came. At Aloha the findings were different. The informants were mostly involved in Daxth Day activities in school, but in activities outside of school they wre more involved than the Reynolds informants. The course activities at Nloha largely account for this, as they gave Aloha informants more opportunities to become involved outside of school.

In general, it appears what courses do insluence the students who take then, and are the major influencing factor. 
BACKGROUND CHARACTERISTICS - TWFOPMANTS AIDD RANDOM STUDENTS

What are the background characteristies of the informants? Do they share common characteristics that would tend to lead them to take an ecology course, or are they similar in background characteristics to the randonly selected group of students?

The following background characteristies were determined for each population: the nurber of children in the family of each student, the length of time each student had lived in his present home, the education of each of his parents, the religious preference of the student, and the kinds of activities that each student participated in out of doors. Combining both schools there were 26 informants and 59 randomiy selected students. Not every question vas asked of every student.

The data on the number of children in tho students' families ware grouped into two categories: students who canie from families of 1-3 children, and students who came from families with 4 or more (maximum was 12). This information is found in Table V. Table $\mathrm{V}$ clearly indicates that students who select the enviromental crisis courses tend to come from smaller families. Very few come from fanilies with 4-12 children. It would appear, then, to be more difficult to get students involved in such courses who come from large families. Since the population problem is usually considered a major component of the environmental crisis (and discussed in both courses), it is possible that students who come from larger families tenc to shy away from a course they think 
might prove uncomfortabie. Should this prove true, the implications for curriculum would be major, in particular how to attract students from larger families into the course in the first place, without deleting a critical component of the course. TABLE V

NUWBER OF CHILDREN IN FAMILY - INECRMANT AND RANDOH

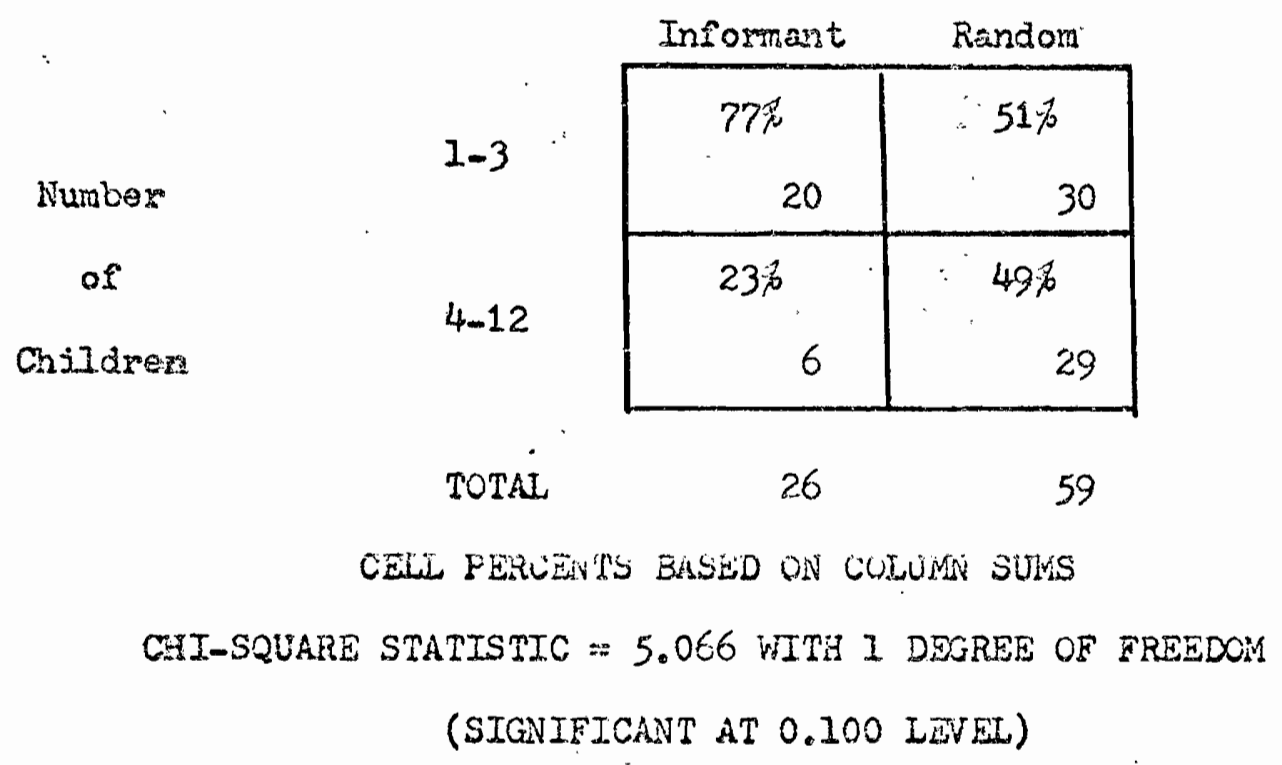

Does the length of residence in the community have any effect on the decision of a student to take an environmental crisis courser Table VI presents data on how long students have lived in their prosent home.

Eren though the chi-square statistic is not significant, it is interesting to note that the percentage of informants who have lived in their home only 0.1 year is the smallest percentage on the table. Any school with high transiency rates would have, it seems, more difficulty in getting students involved in environ- 
mental crisis courses.

\section{TABLE VI}

- LENGTH OF RESIDENCE IN FRESENT HONE

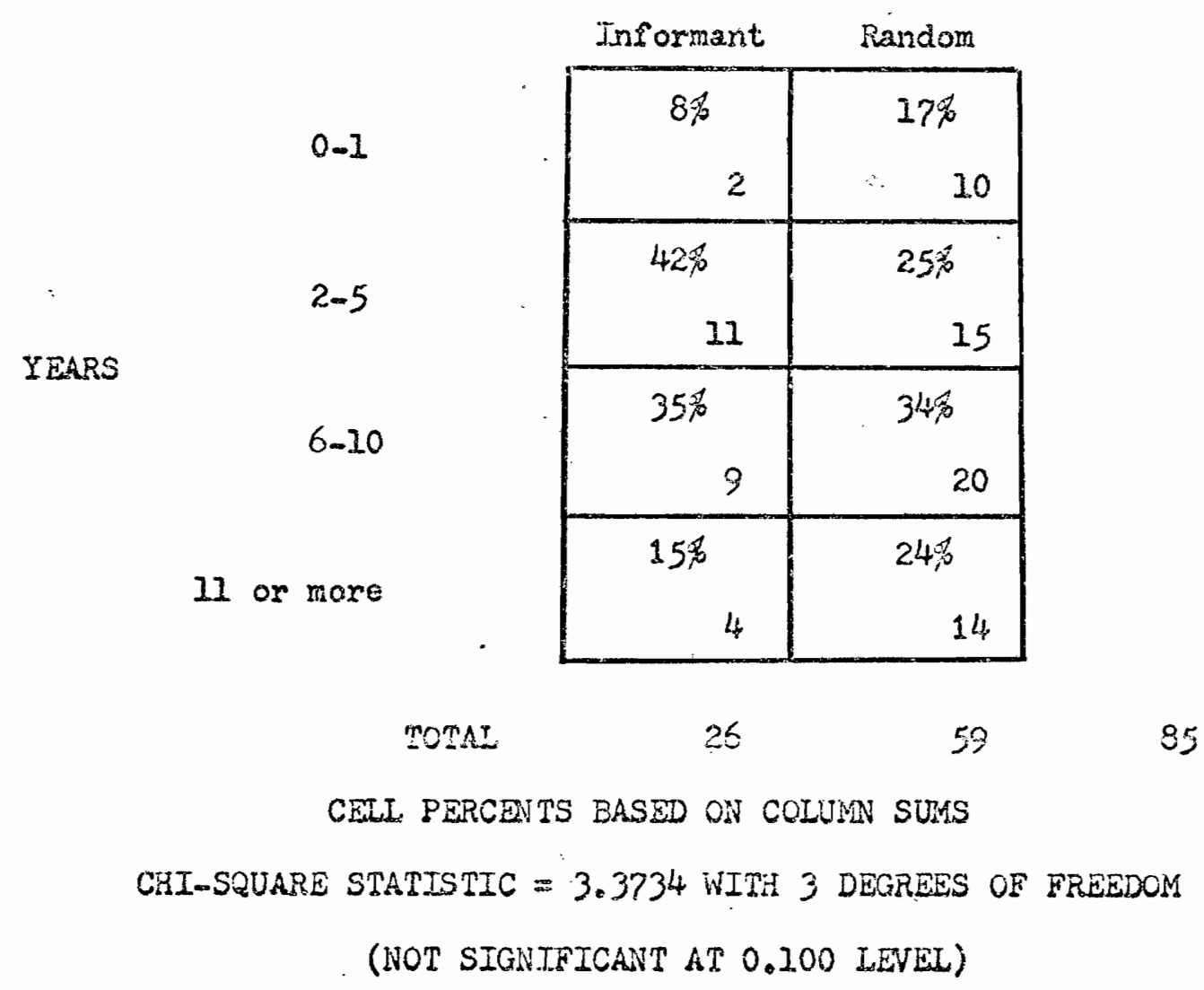

Does the education of the parents of the students make any difference? There was no significant difference betwe the educational atiainment of the parents of the informants and the random students as seen in Table VII and Tablo VIII.

Informants do not tend, then, to cone from nore educated parents than the random students. Therefore, students joining the environmental crisis courses do not seen to coro from more stimulating homes than those students who chose not to take the course. 
TABLE VII

EDUCATTON OF MOTHER

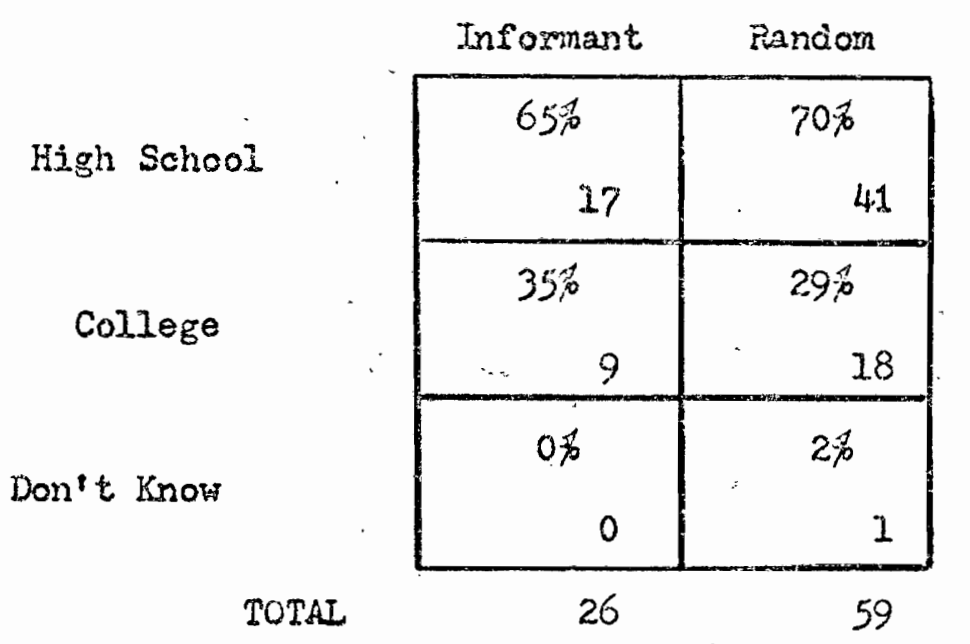

CEII PERCEITS EASED ON COLUNN SUMS

CHI-SQUARE STATISTIC $=0.140$ WITH I DESRTE OF FREEDOM (NOT SIGNIFICANT AT 0.100 LEVEL)
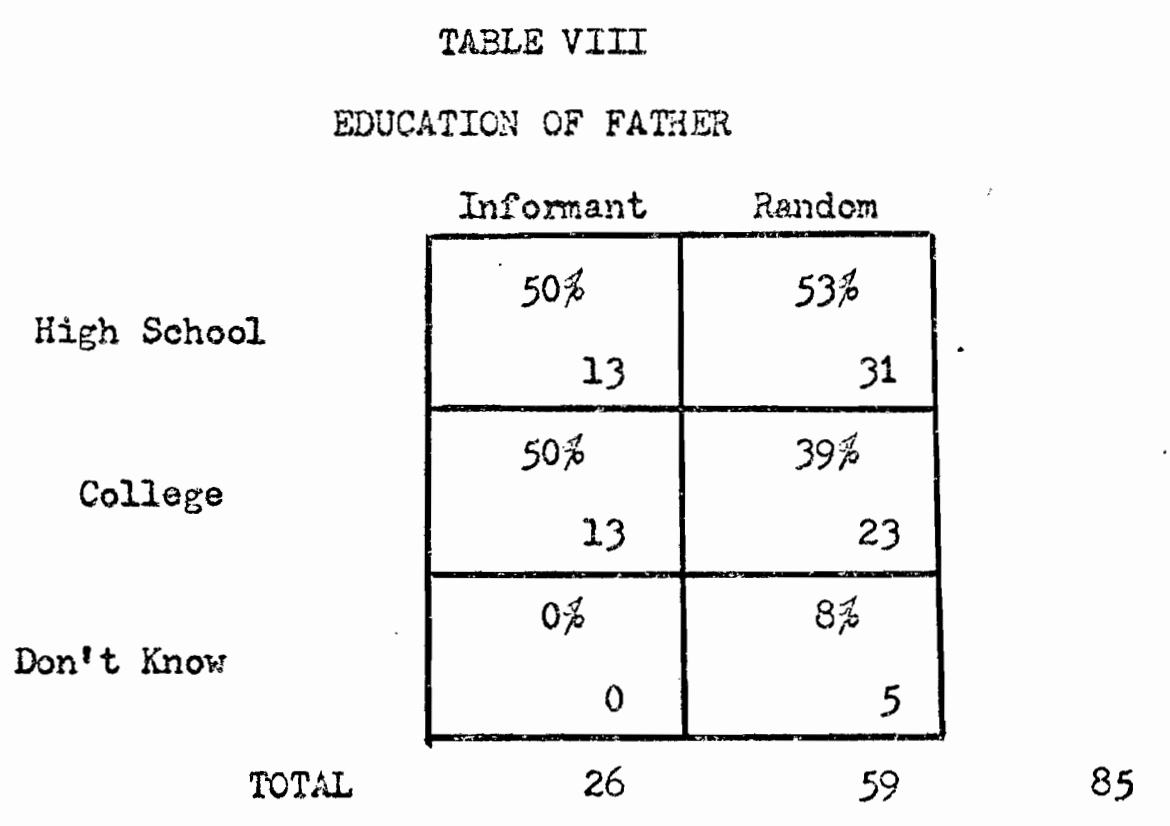
At both schools, Reynolds and Aloha, there also was no difference between the cccupations of the fathers, as the greatest percentage were involved in technical wark and business ( 46 percent of the informants' fathers as compared to 36 percent of the random students' fathers). It could be that there simply were not large enough internal differences in the school populations to pick up any differences on education and occupation, but in more diverse schools such differences might become apparent.

In analyzing the results of the students' religious preferences a significant finding was uncovered:

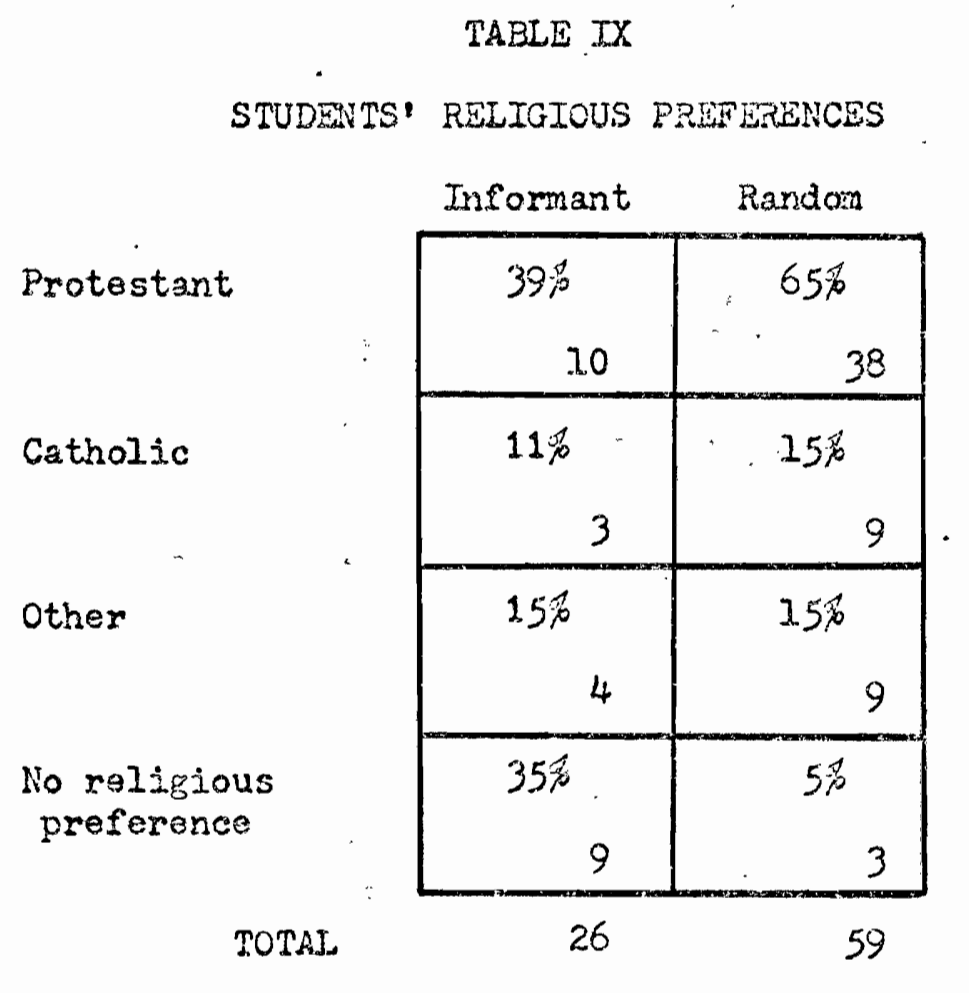

CELI PERCENTS BASED ON COLUN SUMS CHI-SQUARE STATISTIC $=13.4758$ WITH 3 DEGREES OF FREEDOM (SIGNIFICANT AT 0.010 LEVEL) 
The interesting result is in the 'No religious preference' category for the informants. This could inean that the informants are more free-thinking than the random students, more independent, and that this is related to more interest in topies such as the environmental crisis. That finding cannot be interproted from this data, but the significant point is that students who indicate no religious preference tend to take the environmental crisis course.

In analyzing the background characteristics of the informants as compared to the random students, how do the personal activities of the informants compare to the random students? Cutside experiences might be one real difference between ecology-minded students, and others who are not. Is there a difference between the kinds of outdoor activities in wich informants engage compared to the random studients? The results are in Table $X$.

As Table $X$ suggests, informants and random students participate in similar kinds of outdoor activities.

If they engage in similar activities, do they visit wilderness areas with equal frequency? Wildernoss was defined as an area that was isolated and primitive. In Oregon examples from some forest and coastal areas were given. The results point to the fact that there is a difference in such activity, and they are given in Table XI.

The informants do go more often to wilderness areas. The informants may be more appreciative of, and therefore more concerned with, protecting their environment as a result of their frequent trips to wildemess areas, or it, nay bo that the same 
TABIE $X$

OUTDOOR LEISURE ACTIVITIES

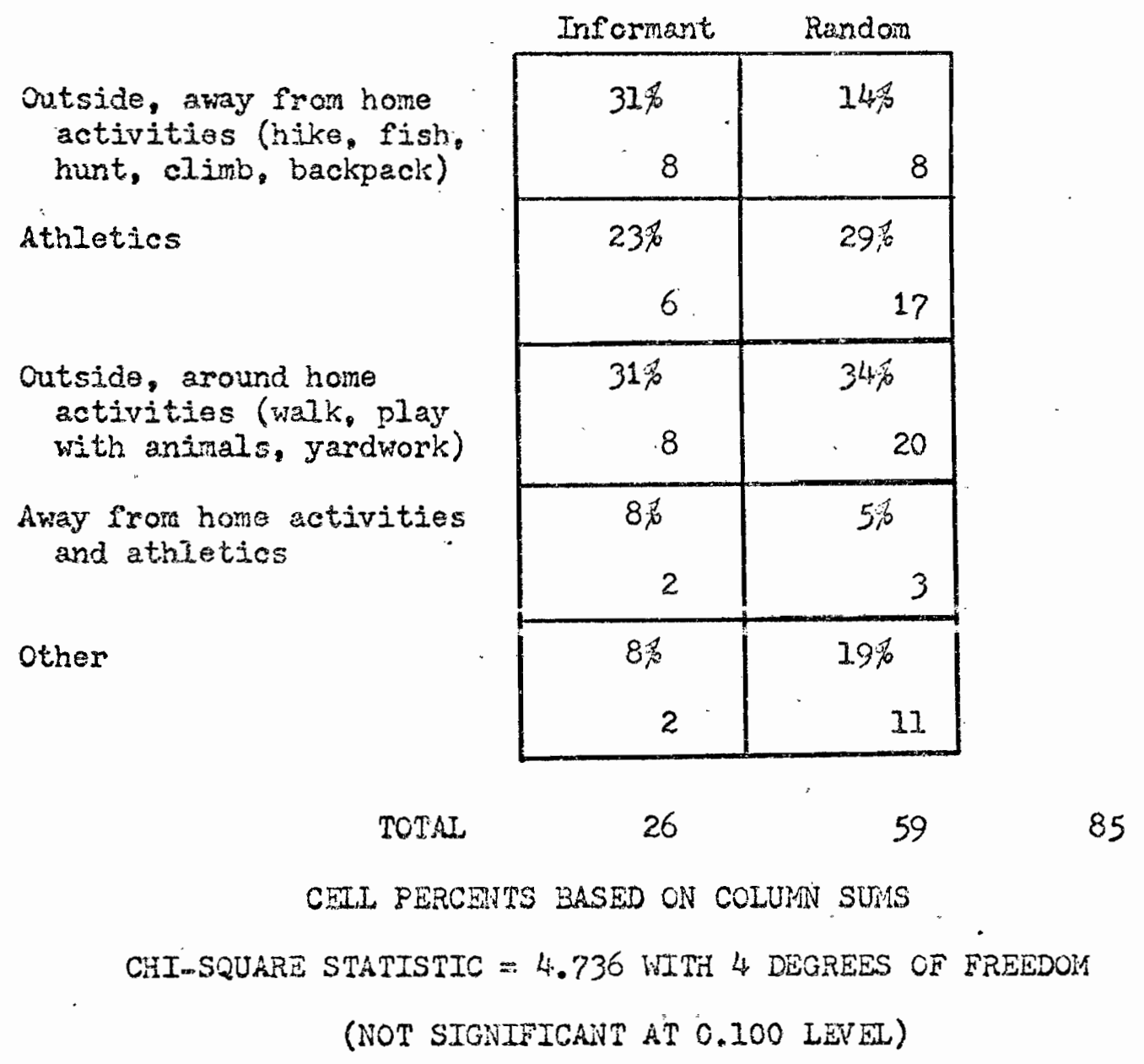


TABLE XI

FREQUENCI OF TRIPS TO WILDERNESS AREAS

\begin{tabular}{|c|c|c|}
\hline & Informant & Random \\
\hline High Frequency & $\begin{array}{l}69 \% \\
18\end{array}$ & $\begin{array}{r}42 \% \\
25\end{array}$ \\
\hline Low Frequency & $\begin{array}{r}31 \% \\
8\end{array}$ & $\begin{array}{l}58 \% \\
34\end{array}$ \\
\hline
\end{tabular}

TOTEL $\quad 26 \quad 59$

85

CELI PERCENTS BASED ON COLUMN SUMS

CHI-SQUARE STATISTIC $=5.2080$ WITH 2 DEGREE OF FREEDOM

(SIGNIFICANT AT 0.050 LEVEU)

type of poople who go to wilderress areas aleo are anviromentply conscious. In either case, they might be more prone to take an environmental crisis course.

The informants also camped more than the random students, and when they did camp they tent camped nore, as compared to the random students who trailer camped. These firdings point to the informants as being somernat different from the random studsnts, utilizing more primitive areas in more primitive hays (terting): and therefore, possibly more interested in environmental issues.

There was, however, no significant difference between informants and random students in their extent of travels, as seen in Table XII. 
TABLE XII

EXTENT OF TRAVELS

Little travel

(Oregon, Washington)

Moderate travel

(Pacific korthwest, California)

fruch travel. (USA)

Not applicable

\begin{tabular}{|r|r|}
\hline $\begin{array}{r}\text { Informant } \\
12 \%\end{array}$ & $\begin{array}{r}17 \% \\
3\end{array}$ \\
\hline $42 \%$ & 10 \\
11 & $54 \%$ \\
\hline $19 \%$ & 32 \\
\hline 5 & $22 \%$ \\
\hline $27 \%$ & 13 \\
\hline 7 & $7 \%$ \\
\hline
\end{tabular}

TOTAL

26

59

85

CELL PERCENTS BASED ON COLUMN SUMS

CHI-SQUARE STATISTIC $=0.087$ WITH 2 DEGREES OF FREEDOM

(NOT SIGNIFICANT)

Although the infomants more often go to wilderness areas, they have not traveled any more extensively than the random students.

Sumary: Backeround Cnaracteristics. Infomants and Random Students

It is important for a course on environmental issues to draw on the experiences of its students, and to provide for differences among students when designing curriculum. There are many significant differences botween those students who tend to take environmental crisis courses and those students who do not. The 
informants come from smalier families and they have less strong religious ties. They have more often taken advantage of opportunities to go to wlldemess areas and they camp more.

The rardom students, on the othar hand, have many characteristics that are similar to the informants. Their parents have similar educational backgrounds, they have lived in their present homes for similar lengths of time, they enjoy most of the same kinds of outioor leisure activities, and they have traveled equally as much.

With these similarities and differences in background characteristics, we turn now to determine whether there are differences in their responses to environmental problems -- how aware and con-

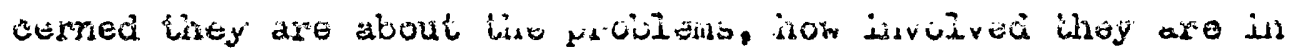
attemoting to do something about then, and wihether these two kinds of differences are related.

THE AWARENESS, CONCERV, AND INVOLVENRNT OF IIFORMANTS AND RANDOM STUDENTS WITH THE ENVIRONENTAL CRISIS

This section will attorapt to determine whether there is a difference in the awarenoss, concern, and involvement of the informants about the enviromental crisis as conpared to the random students. The first part will analyze sone of the differences in the awareness and concern of the informants about the environmental crisis as compared to tho rarion students. First, some pertinert informacion about the students will 
be discussed: their ecological sources of information, their major ecological interests, their ecologieal readings, and their reasons for taking, or not taking the environmental crisis course.

Second, responses will be given to selected, relevant questions of the enviromental crisis in an attempt to determine the differences in the awareness and concern of both groups. Tho questions asked are:

Is there an ecological crisis in the world?

Is there an ecological crisis in the Pacific Northwest? What are tho specific problems that are given to support the contention that an ecological crisis does exist? What do you see as the three most important ecological problems in the rorld?

Why is population a problen?

Does the United States have a population problem?

How do you rate the environmental quality of your community? Are you optimistic or pessimistic about man's chances of semyival?

lan the environmental probiems be solved by technologys

The use of a picture to bring out awareness and concern responses is used as a final example to illustrate differences in the awareness and concern of the informents about the environmental crisis as compared to the random sample.

Tho second part of this section will attempt to determine whether there is a significant difference between both groups in their involvement in ecological activitios in school and outside of school.

Throughout this section representative comments from both groups of students, the informants and the random students, will be used to illustrate the nature of each group's responses. Tho information is drawn from the interview questions and from the 
discussions with the ocological pictures.

Avereness and Concern of Inforniants and Random Students

Eeforo it can be deiermined. if there is a difference between the awarenes and concern of informante compared to a random sample of students, it rould be worthwile finst to learn whore each group receives its ecological information, each group's major ecological interests, and the reasons of each group for taking, or not taking the enviromental crisis course. These factors could influence how the students respond to the questions on the envircrmental crisis.

Whers do students obtain their information on the environmentid crisis, and is trate a difierence on the saurces of information for the informants as comparad to the random students? The sources of ecology information are found in Table XIII.

The courses, along with magazines, appeared to be very major sources of basic information for tho informants, whereas television and magazines were the nost important sources of information for the random students.

Witat were the studonis main ecological interests? The responses to this question are important for curriculum development, for if gathered before the course began, a course could build on those interests. If determined after, the influence of the coarse could be trackod. The results are in Tabie XIV. 
TABIE XIII

SOURCE OF ECOLOGX INFORUATION

Television

Informant Random

Radio

Magazines

\begin{tabular}{|c|c|}
\hline $\begin{array}{l}88 \\
2\end{array}$ & $\begin{array}{l}37 \% \\
22\end{array}$ \\
\hline $\begin{array}{l}0 \% \\
0\end{array}$ & $\begin{array}{r}2 \% \\
1\end{array}$ \\
\hline $\begin{array}{r}31 \% \\
8\end{array}$ & $\begin{array}{l}29 \% \\
17\end{array}$ \\
\hline $\begin{array}{r}8 \% \\
2\end{array}$ & $\begin{aligned} & 7 \% \\
& 4\end{aligned}$ \\
\hline $\begin{array}{r}4 \% \\
1\end{array}$ & $\begin{array}{r}2 \% \\
1 \\
1\end{array}$ \\
\hline $\begin{array}{r}0 \% \\
0\end{array}$ & $\begin{array}{r}28 \\
1\end{array}$ \\
\hline $11 \%$ & $\begin{array}{r}5 \% \\
3 \\
\end{array}$ \\
\hline $\begin{array}{r}480 \\
1\end{array}$ & $\begin{array}{r}307 \\
2 \\
\end{array}$ \\
\hline $27 \%$ & $\begin{array}{r}8 \% \\
5 \\
\end{array}$ \\
\hline $8 \not x$ & $\begin{array}{r}5 \% \\
3\end{array}$ \\
\hline
\end{tabular}

TOTAL

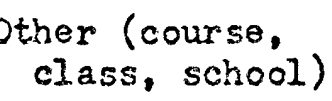

Discussion groups

Speakers

Friends

responsos

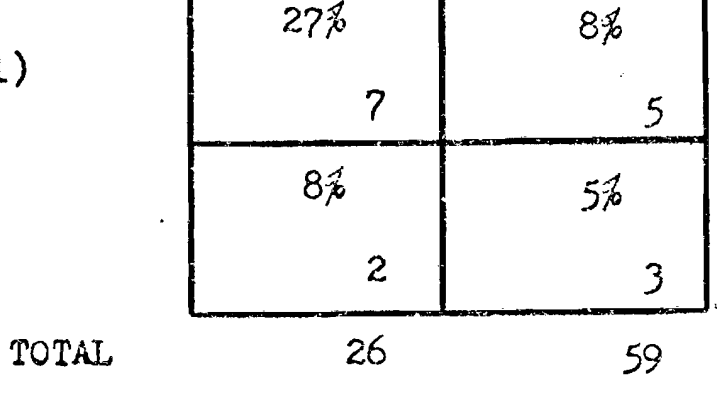

85

GEXI PERCENTS BASED ON COLUNA SUMS

CHI-SQUARE STATISTIC $=12.5145$ WITA 9 DEGREIS OF FREEDUM 
TABLE XIV

MAJOR INTEREST IN ENITRONMENSAL ISSUES

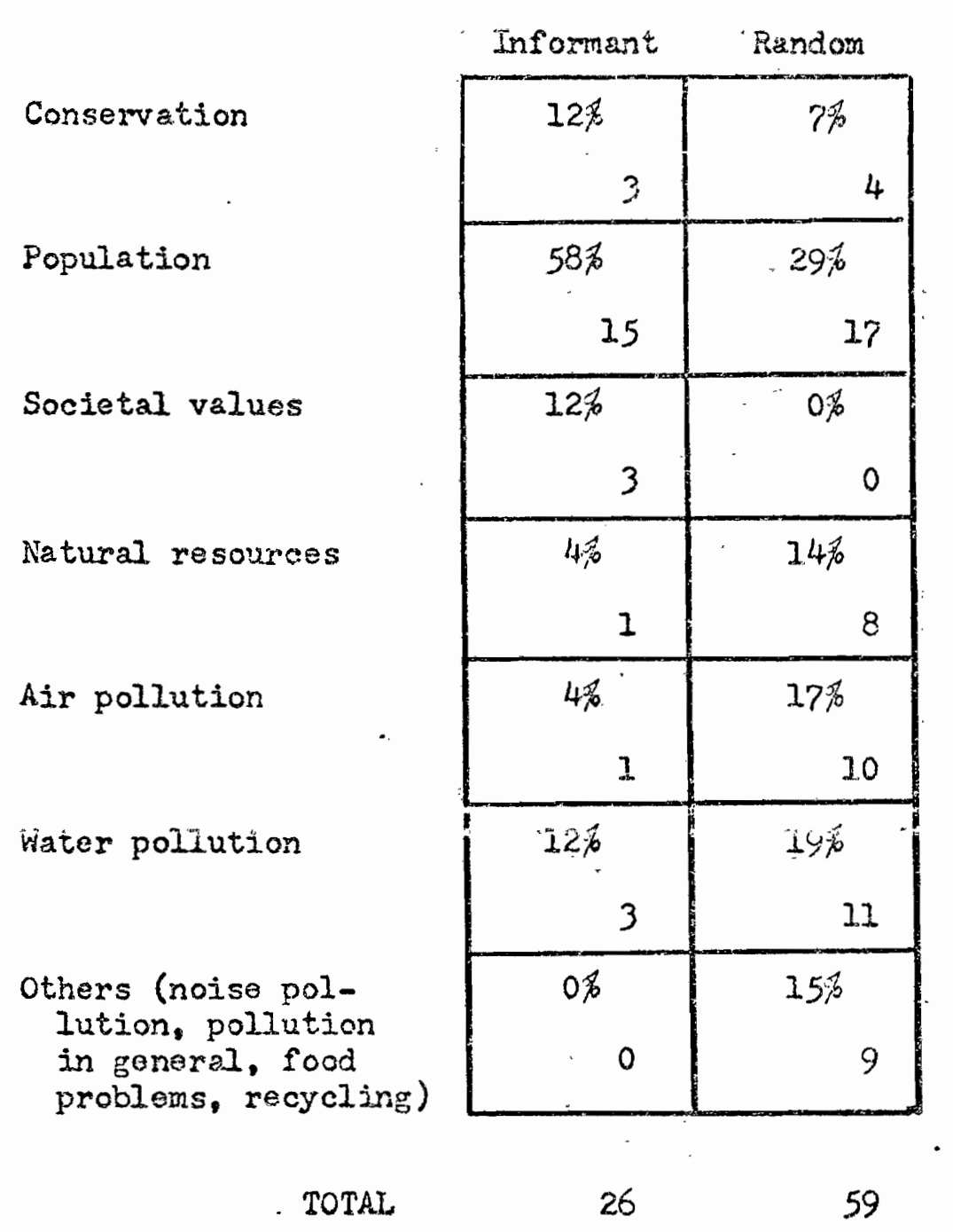

CRII PERCENTS BASED ON COLUMN SUMS

CHI-SQURRE STATISTIC $=19.836$ WITE 6 DEOREES OF FREEDON (SIGNIFICANT AT 0.010 LEVEL)

An interesting finding from this table is the difference in the kinds of interests of the informants as comparad to the random students. The greatest ecological interest of the informants 
is population. whereas population $i s$ much less so for the random students. The random students, generally, seem to be more interested in pollution problems than the informants, ine category of societal values wich a number of informants viewed as their major interest, but which received no response from the rancion students, is indicativo of a different lovel of insight into the problems. It appears that the topic of population would be vorthwile to begin any course, because of the high interest of the many students. Another significant difference between the informants and the random students relating to awareness and concern with environmental problems is the amount and kind of reading that oach group of students does. Where. students receive their information on ecology is very important for curriculum development, for it is often from readings that students gain knowledge to form opinions. If the sources of information are biased and inaccurate, the problems in reteaching the student are very difficult. Students wero asked to name any readings in ecology that had influenced thom, and the results are in Table XV.

Books that nore aseigned in class, such as Ehrlich's The Pooulatjon Bomb, had much effect on the studerts. Often, in discussing the pictures on in the interview conversation, the students who had read books such as this one, would discuss what Ehrlich had said about the particular topic under discussion at the time. The random stwionts tho had read this book were equally as impressed as the inforngnts. Certainly, the problems in finding 
appropriato books and readings for curriculum for all kinds of students is $r_{0} 0$ easy task, but books appear to have been influential with the students in this study.

TABLE' XV

INELUEHTIAL ECOLOGY REDDIIGS

Iittle or no reading

Kentions specific books. articles

Kentions resdings in general.

Other rejoones

Cannot remember

$$
\text { Informant Random }
$$

\begin{tabular}{|r|r|}
\hline $8 \%$ & $31 \%$ \\
2 & 18 \\
\hline $69 \%$ & $32 \%$ \\
18 & 18 \\
\hline $15 \%$ & $22 \%$ \\
4 & 13 \\
\hline $4 \%$ & $2 \%$ \\
\hline 1 & 1 \\
\hline $4 \%$ & $15 \%$ \\
\hline
\end{tabular}

TOTAL $\quad 26.59 .85$

CEL PFECRTS BASED CN COLUN SUSS

CHI-SQUARE STAIISTIC $=13.133$ WITH 4 DEAREYS OF FREEDOH

(SIGRIFICANT AT 0.010 LEVEL)

The environmental crisis courses were offered in both schools. Why then, did seme students choose to take the course, while others did not? When asked why they signed up for the environrental crisis course, the informants gave the replies in 
Table XVI.

TABIE XNI

INFORMANTS: REASONS FOR TAKING COURSE

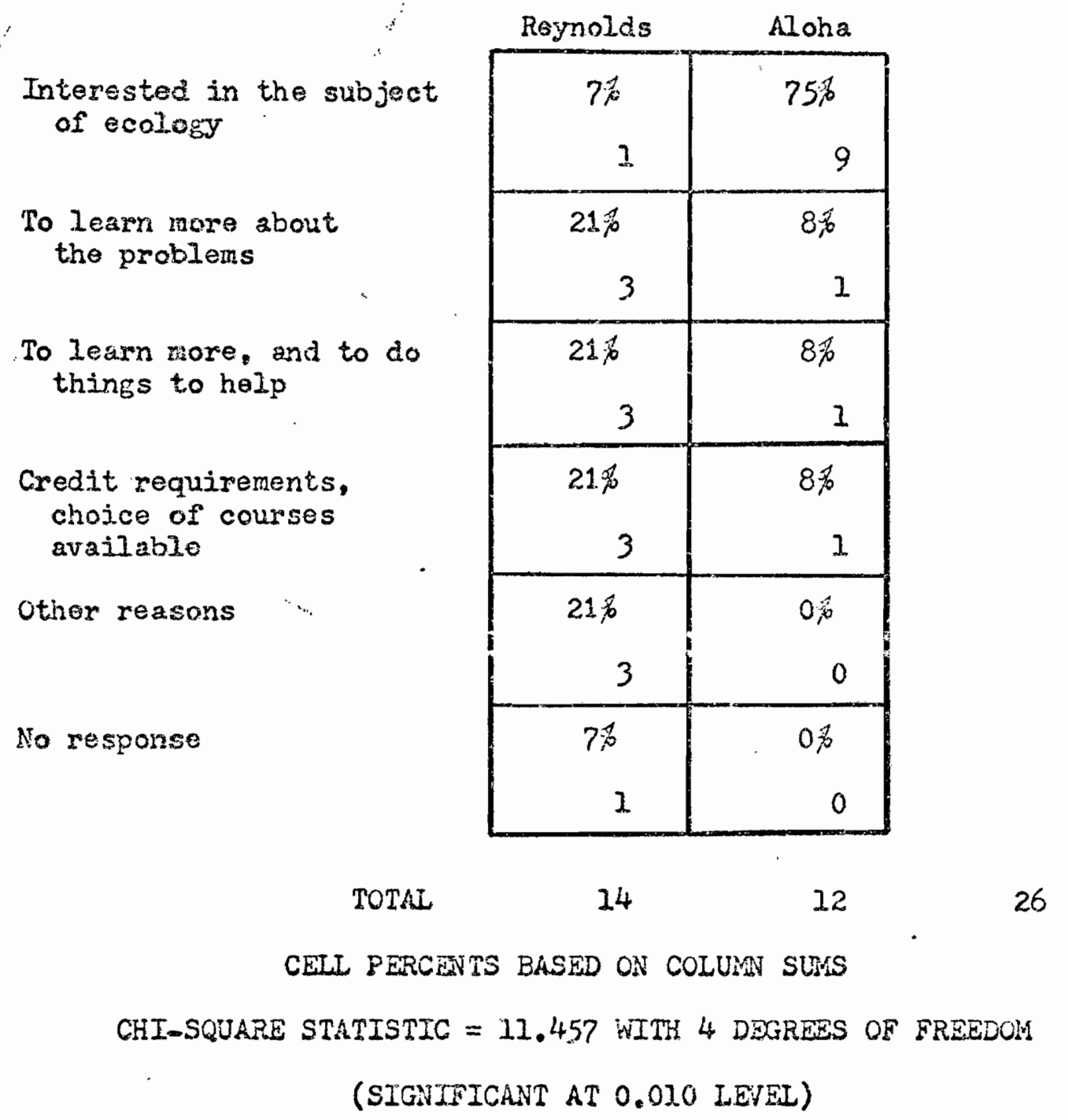

The reasons for taking the course vary considerably between the two schools, but if one considered the first three cells to in. dicate concern for the environment on the part of the students, the greatest percentage of informants took the course for such a 
reason. Both of these courses were elective. The students could choose the course in place of another social studies course, and still meet the proper requirenents. It appears from this table (XVI) that tha students who did take the courses were interosted in the topic, and would, therefore, bo more motivated to loarn. Persons developing curriculuril for such coursos should determine whether the materials they are developing aro for elective courses, or for a required course that all students in tho school have to take. Teaching students who are already interested is quite different from reaching those who are not.

When the informants were asked why thoy became involved in ecological activities, their concorn for the environment again

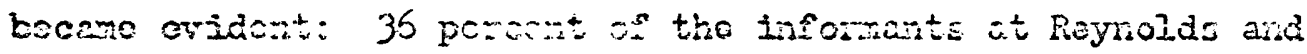
50 percent of the inforiant,s at Aloha became involved because of their concern for the erviroment. They wanted to help or they felt that somoone needed to do something.

Someone's got to do something arout it $\ldots$ the nore people doing it, the more people secing what you're doing. the more poople involved.

I ranted to do something as the problems were getting worse. I wanterl to do sorething to help it a little.

These responses from informants are certainly different in nature from the rancen stident who did not tako the environmental crisis course because he was "not interested in the cturse." The responses of the random students for not teking the environmental crisis course are found in Table XVII. 
PABLE XVII

REASONS FOR RANDOY STUDENTS NOT TAKING THE ECOLOGY COURSE

hanted to take another courso -momenom

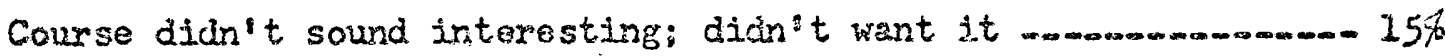

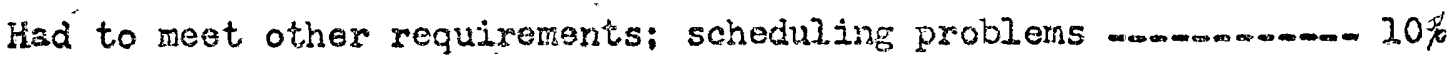

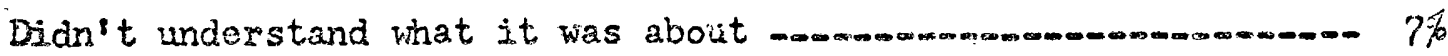

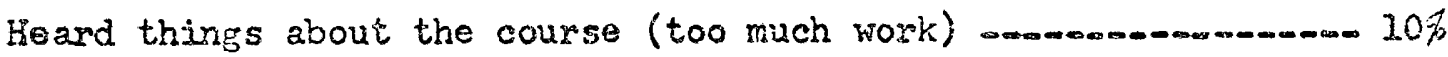

Could learn about ecology from other scurces than course a........ $2 \%$

Cther reasons -

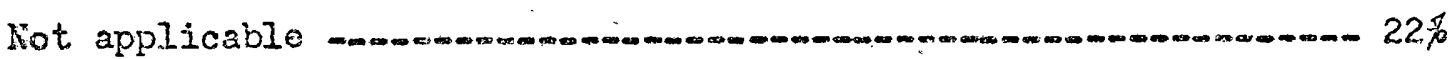

It is evident from the above that a large percentage of the random students just did not want to take the environinental crisis course.

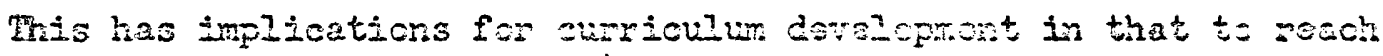
a11 students, whether interested in environmental issues or not, ecology will have to be integrated into the required courses of tho school.

Selected questions will now be analyzed in an attempt to determine differences between the informants and the random students iri their awareness and concorn with the environmental crisis.

Do the informants and random students see an ecological crisis in the world, and in the Pacific Northwest? Both groups, the informants and the randon students, see an ecological cxisis in not anly the worlds but also in the Pacific liorthwest, as incicated in Table XVIII and Table XVIX. While the differences are not statistically significant, in terms of percentages, some leanings are 
apparent. More informants see an scological crisis in the world and in the Pacific Northwest than do randon students; randoms tend to see the crisis point as more distant.

TABLE XVIII

IS THERE RN ECOLOGICAL CRISIS DN THE WORLD?

\begin{tabular}{|c|c|c|}
\hline${ }^{\circ}$ & Informant. & Pandom \\
\hline Yes & $\begin{array}{l}84 \% \\
22\end{array}$ & $\begin{array}{l}63 \% \\
37\end{array}$ \\
\hline No & $\begin{array}{r}4 \% \\
1\end{array}$ & $\begin{array}{l}5 \% \\
3\end{array}$ \\
\hline Don't know & $\begin{aligned} 4 p & \\
& 1\end{aligned}$ & $\begin{array}{l}780 \\
4\end{array}$ \\
\hline $\begin{array}{l}\text { Not yet, w1] Le } \\
\text { if keeps going }\end{array}$ & $\begin{array}{l}89 \\
2\end{array}$ & $\begin{array}{r}25 \% \\
1.5\end{array}$ \\
\hline
\end{tabular}

CEIL PERCENTS BASED ON COLUNAN SUMS

CHI..SQUAFE STATISTIC $=4.4073$ WITH 3 DERREES OF FREEDOM

(WOT SIGNIEDCANS AT 0.100 LEVEL) 
TABLE XIX

IS TRERE AN ECOLOGTCAL CRISIS IN THE PAGIFIC NORTHNEST?

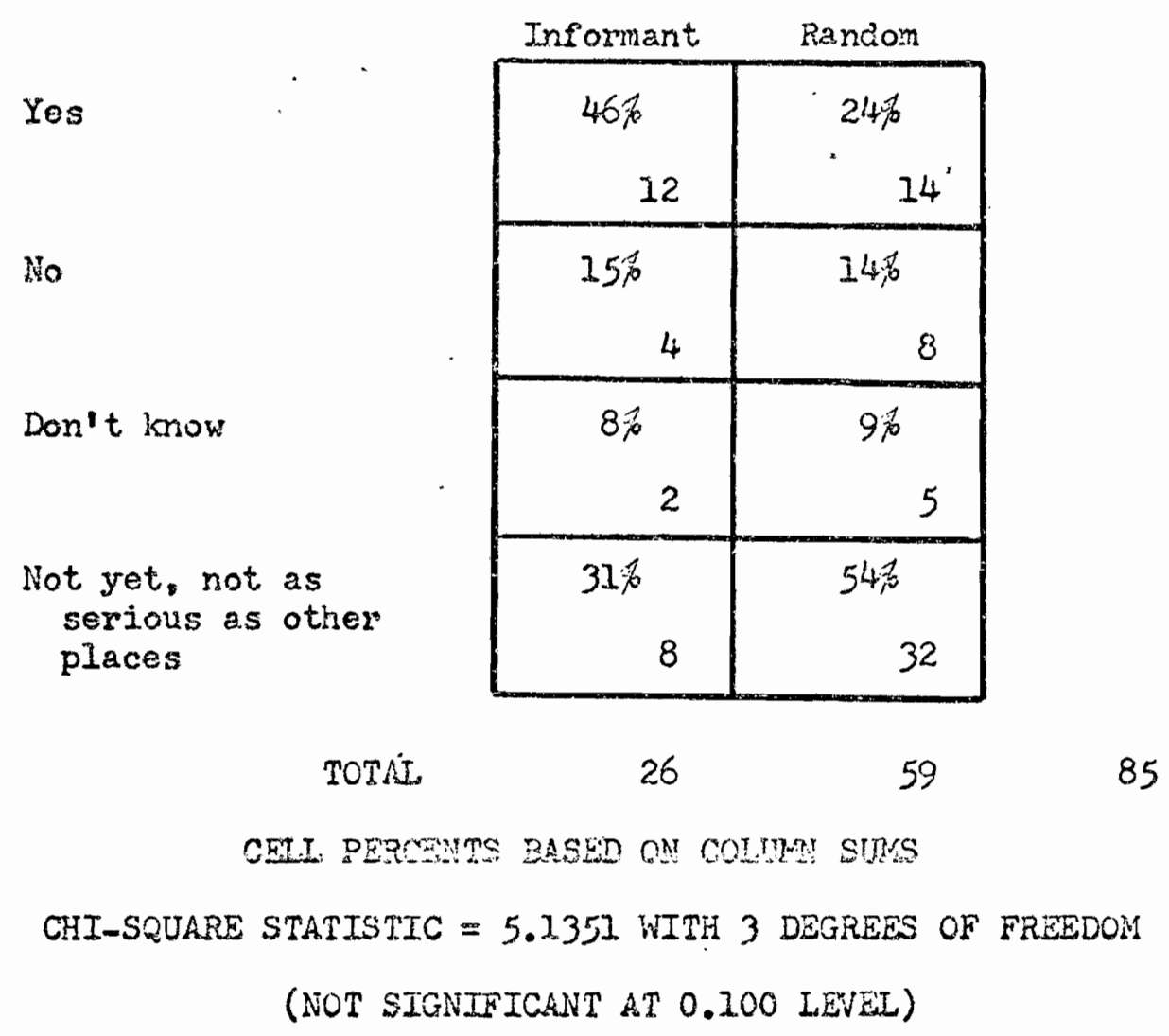

There are some implications for curriculux here. Regardless as to whether it was the course that made a difference, or whether the students who took the course were concerned in the first place, the signifieance is that after the course, the informants do see more of a crisis than the random students. The combination of a curriculum and an elective course can teach thet an environmental crisis does exist, not only in the world, but also in the Pacific Northwest.

Not only do both groups of students see an environmental 
crisis existing, as indicated in Tables XVIJI and XVIX but they also think that man's survival on earth is erdangered. 58 percent of the informants and 54 percent of the randon students responded that yes, man's survival is enciangered. When asked to mention specifie problems, or reasoris why such a crisis existed in the world and in the Pacific Northwest, differences began to appear between the informants and the random students. 77 percent of the informants and 49 percent of the random students mentioned a specific problem to support their contention that an ecological crisis existed in the world. What the students saw as major problems are found in Table $\mathrm{XX}$.

It is interesting to note that changing people's attitudes and awareness and increasing education ranked the highest for the informants. For example:

People don't understand that they're really ruining their environment.

We need nore crises, If we had a really good crisis, it would make people stop and think. That's. What it's going to take to make people aware about mat's going on, to think a Iittle bit.

The random students mentioned the problems of population and pollution most frequently when asked what they saw as causing an ecolosical crisis in the world. For example:

Greppopulation and ajr pollution - - those two will becone the most serious.

Ey 2380 we'll have to wear gas masks if wo don't do sometring about the ajr. I think we better do something before we have to wear gas nasks. 
If something isn't cone, you'II have no air with air pollution. With ait pollution, you'il have weak people. dying people. And on down the line w you'll ruin all the natural beauty that they ever had. with overpopulation nobody will haye enough food and they'll be broathing in dirty air and it'll cause a lot of disease. It'll really ruin everything if it keeps going.

TABLE XX

SPECIFIC PROBLESS WENTIONED ON WEY AN ECOLOGICAL CRISIS EXISTS IN THE WORLD

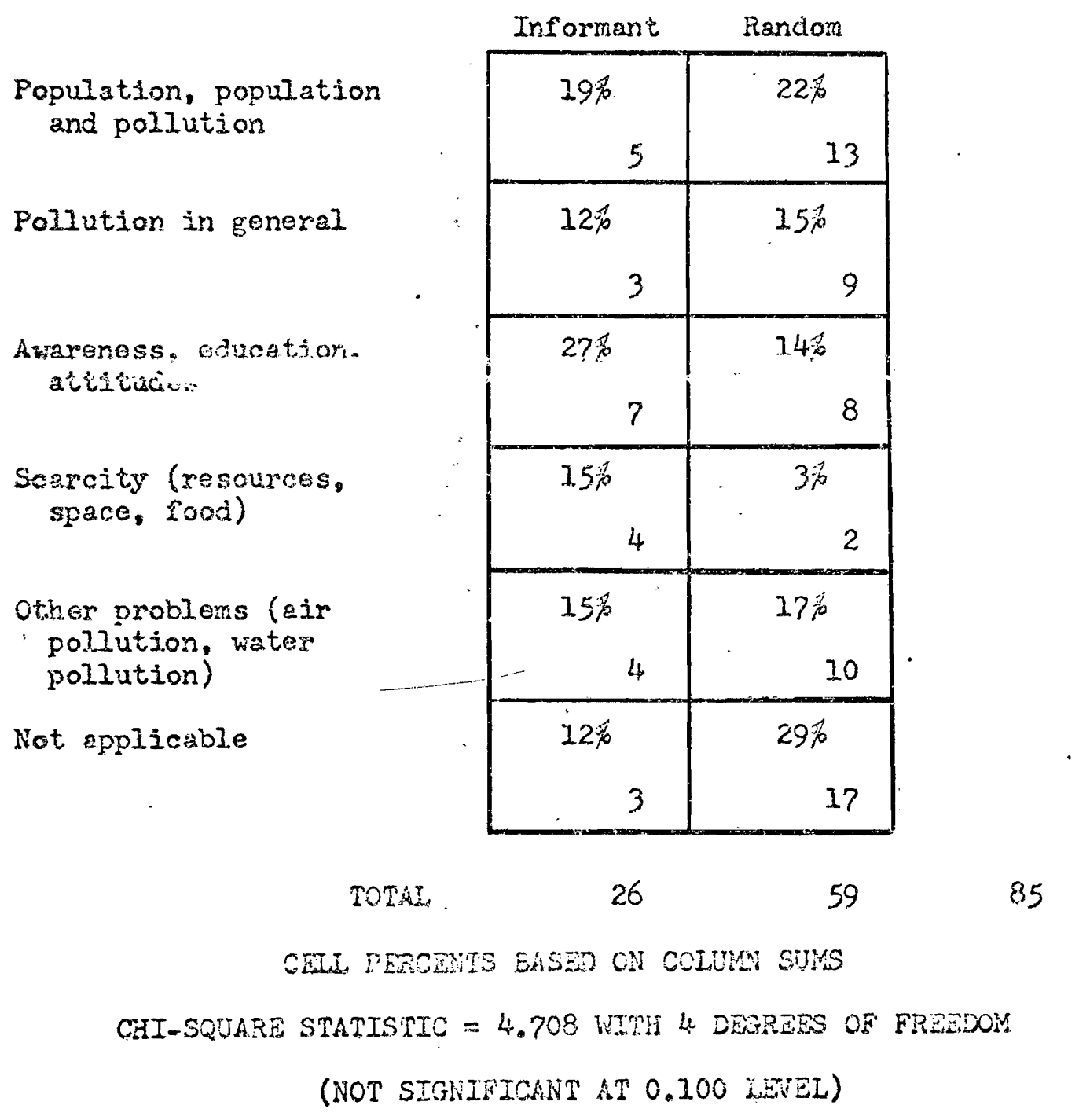


In responding more specifically to tho issue of whether $a n$ ecological crisis existed in the Pacific Northwest, 39 percent of the informants and 42 percent of tho random stuifents mentioned somo kinid of pollution (air pollution, water pollution, or land pol-

Iution) to support their viewpoint. As might bo expected from

the more local focus, the responses to this question included more personal observations and more spesific referonts. For example, informants responded:

Now wo have to reservo campsites. It isn't as crowied as Beston, but as great outdoors land. it loses with more people. It loses more and more wilderness. We had so much rater, but if you pollute it, it's gone, you can see it, it's not good for enything.

Right now we're not as bad as Califorria. We'Il start to get there because everyone is noving out here because of the problems elsewhere.

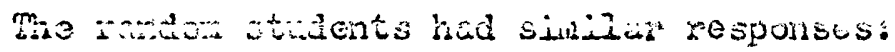

It's not as bad as other places, but little by little it's getting worse, like our air polzution wasn't bad a few years ago and now it's getting worse. We're seeing more litter, and our streams are getting more polluted little by little.

Not any serious probiers there, exeept for vater pollution - the willamette shoulan't be like that.

I don't think ours is as bad as everyono elso's. 'he're pretty lucky. 'is're not overpopulated really. Cur rivers are getting dirtier. Iike the Columia. Our air is getting dirtier w you notice it when you're in Fortland. We're not as bad off. I don't think we have a crisis yet, but when we have a crisis, I think other places will be really bad off, like Los Angeles.

In general, as the questions focused on the more local area, the responses of the random and informant students tended to become more alike, although basically more informants than random students thought the crisis was here rather than coming 
TABLE XXI

THREE MOST IWPORTANT ECOLOGICAL PROBLEMS IN THE WORLD

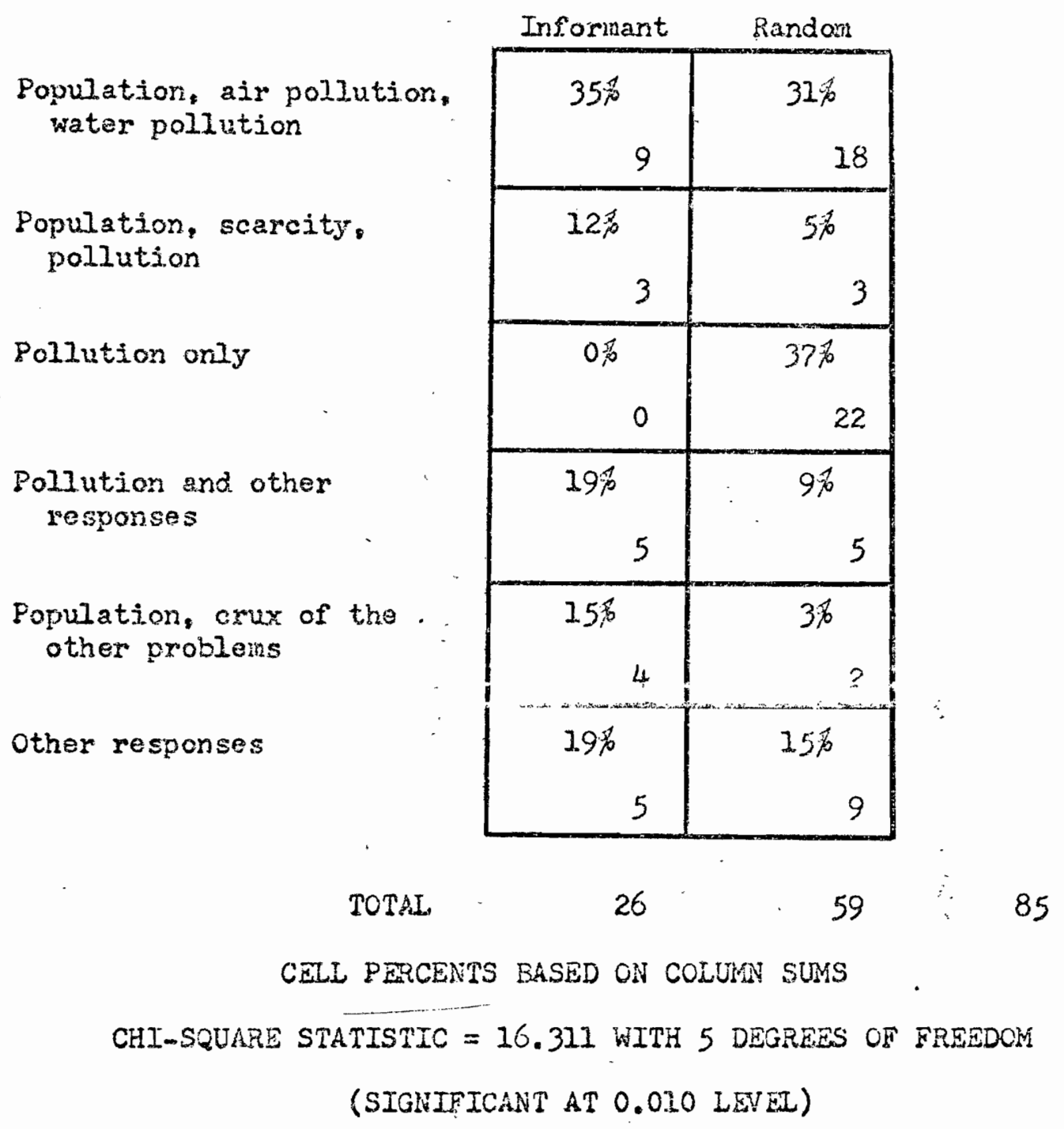

This table indicatos that the informants wore much more interested in the probleins of population, while the random students were more interested in the problens of pollution. Since the random students receive most of their information from television, it might be assuried that the problems of pollution are 
more stressed in the mediz than are the problems of population. But this is an assumption.

Along the same lines there was a significant difference between the randon students and the informients in their response to the question, why is population a problem, as seen in Table XXII.

TABLE XXII

WIY IS POPULATION A FROBLEII?

SociaI problems

Crux of all other problems

Informant Random

Probjem of scarcity

Not a problem (something else is)

Other problems

Not applicable

\begin{tabular}{|c|c|}
\hline $2 \%$ & $12 \%$ \\
$2 \%$ & 7 \\
\hline $54 \%$ & $20 \%$ \\
14 & 12 \\
\hline $3 i \%$ & $3 \% \%$ \\
8 & 22 \\
\hline $8 \%$ & $5 \%$ \\
\hline 2 & 3 \\
\hline $0 \%$ & $15 \%$ \\
\hline $0 \%$ & 9 \\
\hline 0 & 6 \\
\hline
\end{tabular}

TOTAL 26 59

CELL PERCENTS BASED ON COLUMA SUKS CHI-SQUARE STATISTIC $=10.688$ WITH 4 DENREES OF FREEDOM (SIGNIFICANT AT 0.050 LEVEL) 
As can te sean rom Table XXIJ, the greatest percentage of informants ese population as the crux of the other environmental problens, and so stated with vivid firality. "Overpopulation is the steri of 2 ti the environmental problems a. in particular, pollution. depletion of ratural resources," statid one informant. "We live on Spaooship Earth and there's only so much material, and when you have an overabundance of people using those limited materials, some things are bound to give -- shortage of food, famine, disease." Another informant commented succinctly: "ill ecological problems result from us. The more of us, the more the strain on our environment."

The random students, on the other hand, saw problems of scarcity, or crowding, or Iimited spece as separate problems, not connected to population as a causal factor, nor interrelated: "There's not enough room for peoplo to live."

After the students had mentioned reasons why population was a problem, they wexe then asked if they thought the United States had a population problem. The results are similar in kind to the difference in responses between an ecological crisis in the world versus one in the pacific Northwest. The data can be found in Table XXIII. The informants decidedly see the United Statas having more of a population problem than do the randon students. frgain, it is diffictlt to determine whether this is an effect of the courses or not, although the weight of evidence would suggest it is. For the random students the problem is away from thom, in certain areas "Iike New York City." For the infoments it is not. For the random 
students the problems of the environment in New York City are isolated from persons living in Oregon.

\section{TABLE YXIII}

DOES TEE UNITED STATES HAVE A POPULATION PROBIEM?

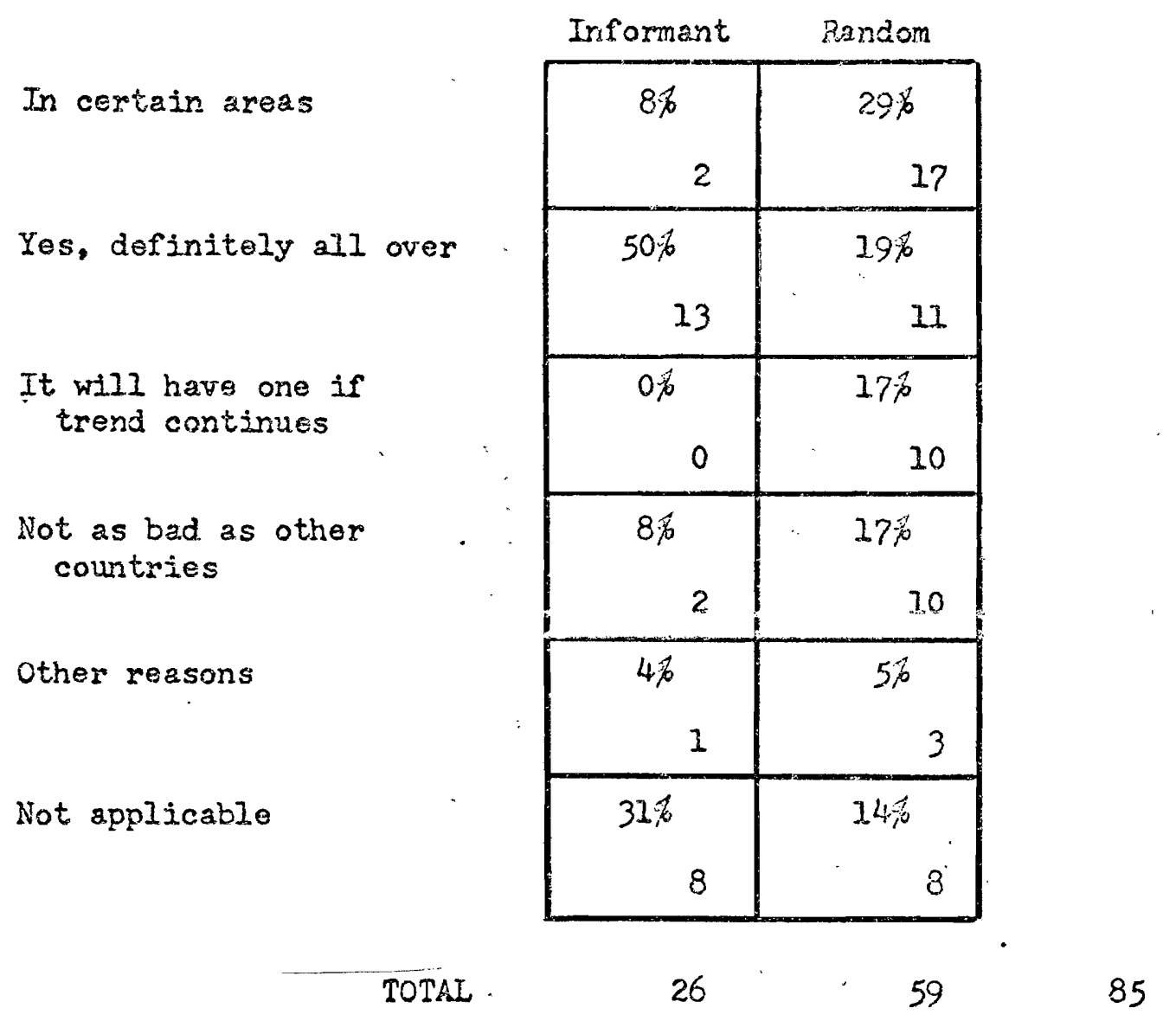

CEIL PERCENTS BASED ON COLUNN SUMS

CHI-SQUARE STATISTIC $=16.286$ VITH 4 DECREES OF FREEDOM (SIGNIFICANT AT 0.010 LEVEL)

One implication for curriculum development is to teach students concepts such as "web of life," "interdependence," and "balance of nature." Such an awareness of man's interdependence 
is the crucial difference between the informants and the random... students. There is less of a world crisis, and less of a local ecological crisis than seon by the informants.

To further this analyeis, how do the students, informants in contrast to the randon, rate the quality of the environment of the comunity in which they live? It is not knom whother the difference in the responses of the tho groups was due to the fact that the infomants had just finished the environmental crisis course. However:

TABLE XXIV

ENVIROMMEITAL PATING OF COMUNITX

\begin{tabular}{|c|c|c|}
\hline & Informarit & Rendom \\
\hline Excellent & $\begin{array}{r}4 \% \\
1\end{array}$ & $\begin{array}{r}98 \\
5\end{array}$ \\
\hline Good & $\begin{array}{r}398 \\
10\end{array}$ & $\begin{array}{r}59 \% \\
35\end{array}$ \\
\hline Fair & $\begin{array}{l}398 \\
10\end{array}$ & $\begin{array}{l}318 \\
18\end{array}$ \\
\hline Poor & $\begin{array}{r}15 \% \\
4\end{array}$ & $\begin{array}{r}210 \\
1\end{array}$ \\
\hline Not sure & $\begin{array}{l}48 \\
4\end{array}$ & $\begin{array}{r}0 \% 0 \\
0\end{array}$ \\
\hline TOTAL & 26 & 59 \\
\hline
\end{tabular}

CELL PERCENTS BASED ON COLUMN SUSS CHI-SQUARE STATISTIC $=8.226$ WITH 3 DEQREES CF FREEDOM (SIGNIFICANT AT 0.050 JEVEL) 
For whatever reasons it appears that after the courses were over, the informants hold a poorer impression of their communities than did the random students. The environmental crisis courses, in discussing the environmental problems that exist, could very oasily have mado the infornants more aware of such problems in their own neighborhoods. The random students would not have had the benefit of the course.

There are some problems that could be created for curriculum as a result of these findings. Do envirommental crists courses turn out diserchanted students? If so, the possibilities of upsetting parents and the community are substantial. On the other hand, the environmental crisis courses may appeal more to mal-contents. At any rate a course would have to be carefin? not. simply to destroy a student's impression of where he lives. If it presents environmental problems, it should also give constructive things that the student might do to help improve his neighborhood.

Perhaps the difference between the informants and the random students is the difference between awareness and concern. The random students, for the most part, are as aware of the problems as the informants, but as can be seen in Table XXY, they do not view the problems as critical as the informants do.

The informants soe the crisls as contemporary and hold fewer hopes that man will bs able to reverse the trends and solve his enviromental problems. The random students belisie that the problems are not yet as critical, and that solutions can be found 
to the problems in tine to prevent any danger to man's survival.

TABLE XXV

OPTIIISM VERSUS PESSDIISM OF MAN!S CHAYCRS OF SURV IVAL

\begin{tabular}{|c|c|c|}
\hline & Informant & Ranciom \\
\hline \multirow[t]{2}{*}{ Optimistic } & $35 \%$ & $46 \%$ \\
\hline & 9 & 27 \\
\hline \multirow[t]{2}{*}{ Pessimistic } & $50 \%$ & 22,8 \\
\hline & 13 & 13 \\
\hline $\begin{array}{l}\text { If trend continues, } \\
\text { pessimistic; if } \\
\text { not, optinistic }\end{array}$ & 8 & $\begin{array}{r}108 \\
6\end{array}$ \\
\hline \multirow[t]{2}{*}{ Don't know } & $4 \%$ & $9 \%$ \\
\hline & 1 & 5 \\
\hline \multirow[t]{2}{*}{ Not applicable } & 48 & $24 \%$ \\
\hline & 1 & 8 \\
\hline
\end{tabular}

TOTAL

26

59

85

CEIL PERCENTS BASED ON COLUNA SUNS

CHI-SQUARE STATISTIC $=5.404$ WITH 3 DESREES OF FREXDOM (NOT SIGHIFICANT' AT 0.100 LEVEL)

Certainiy, a course on the environmental erisis would not want inerely to destroy positive outlooks of students concerning man's survival. But a raive view would have to be made more complex. To do this, a course yould have to present to the student opposing viewpoints on the various problems, and desl with unexamined boliefs, as the feelings held by many that science and 
Students who have not taken the environmental crisis course tend more to believe that solutions vill be found to the environmental problems, but the informants see the situation differently to some extent. Whether it is the course that made the difference cannot be determined hore. Nsither is it clear whether this view is merely a negative outlook, or whether it is a balanced and complex judgment.

Picture 15, showing eand buggies on the dunes, illustrates well a final example of the difference in concern for the envirome ment between the informants and the randon students. When asked if they saw any ecological problems in the picture, the students gave the responses in Table XXVII.

This picture puzzled many random students, since, if no problems were apparent to them in the picture, at least from outward appearance, they had difficulty in interpreting it. It was ranked last by the random students 29 percent of the time. Most of the comments for this picture were similar to the followings from a random student: "That's fun, it really is. It's something to do, entertainment. We have one and we often visit the dunes."

One problem for curriculum development resulting from the previous discussion is how to diseuse changing life styles with students. Technology and affluence have made such items as dune buggies and snowmobiles available to many poople, but if the environment is to be protected, man may have to do without, or at least limit such luxuries. Atrempting to bring atout a change 
in attitudes of today's youth toward life styles will be no easy task for those interested in cleveloping curriculum on ervironmental issues.

TABLE XXVII

ECOLOGICAL PROBLEWS IN PICTURE $15 ?$

No probiems

Disturbing the land, tearing it up.

Not hurting the land because it's desert

Noise pollution, the need for quiot areas

Air pollution

Other reasons

Not applicable

\begin{tabular}{|r|r|}
\hline Informant & Random \\
\hline $0 \%$ & $31 \%$ \\
\hline $29 \%$ & 18 \\
\hline 5 & $72 \%$ \\
\hline $23 \%$ & $9 \%$ \\
$6 \%$ & 5 \\
\hline $23 \%$ & $12 \%$ \\
\hline 6 & 7 \\
\hline $8 \%$ & $12 \%$ \\
\hline 2 & 7 \\
\hline $23 \%$ & $20 \%$ \\
\hline $4 \%$ & 12 \\
\hline 1 & $3 \%$ \\
\hline
\end{tabular}

TOTAL 26 59 85

CELL PERCENTS BASED ON COLUEN SUMS CHI-SQUARE STATISTIC $=13.373$ WITA 5 DEGREES OF FREEDOM (SIGNIFICANT AT 0.050 LEVEL) 
Ecological Involvoment of Informants And Rardom Students

Both groups of students are aware than an ecological crisis exists not only in the world, but to some extent in the Pacific Northwest. The students are awere enough to be concerned that man's survival is endangered. The question then becomes, if they see an ecological crisis existing, how involved have they been in trying to do something about the problems? This section will analyze the ecological involvenent of the informants and the random students in school and outside of school, as well as each student's willingness to be involved in changing his life style.

Both the informants and the random students were asked about their involvement in ocological activities in school, and they responded in the mamer indicated in Taple sivily, Farth lagy, 1970, was a large affair for many schools. Consequently, many of the random students trere irvolved in it -a attending lectures, walking to school, or pickine up litter.

It is interesting to note that no random students were involved in personal long-term or short-term activities. Many of the informants were involved in activities that stemmed from their environmental crisis course. The bis difference between the random students and the informants is in the last cell. 48 percent of the random students wore not involved at all.

The difference in the involvement of informants outside of school as compared to random students was over more significant than in school. This information is fourd iri Tabio XXIX. 
TABLE XXVIII

ECCLOGICAL RNVOLVEMENT IN SCHOOL

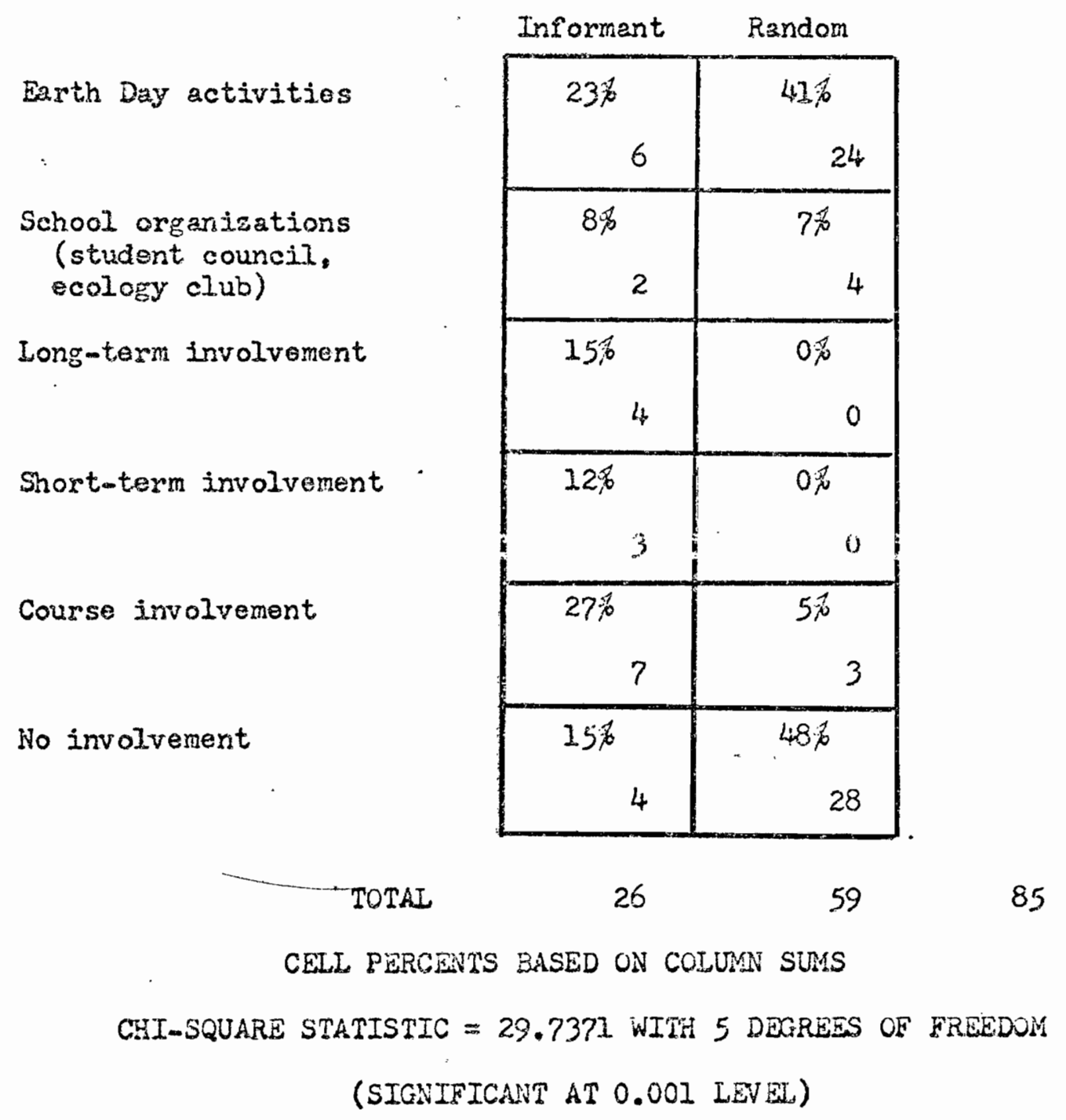


TABLE XXIX

ECOLOGICAI TNOLVEAENT OUTSIDA OF SCHCOL

\begin{tabular}{|c|c|c|}
\hline & Informant & Riandom \\
\hline $\begin{array}{l}\text { Individual activities - } \\
\text { very infolved and tries } \\
\text { to convince others to be }\end{array}$ & $\begin{array}{l}1970 \\
5\end{array}$ & 0 \\
\hline $\begin{array}{l}\text { Individual activities - } \\
\text { very involved }\end{array}$ & $\begin{array}{r}8 \% \\
2\end{array}$ & 0 \\
\hline $\begin{array}{l}\text { Individual activities - } \\
\text { partially involved and } \\
\text { tries to convince others } \\
\text { to be }\end{array}$ & $\begin{array}{l}398 \\
10\end{array}$ & $\begin{array}{r}10 \% \\
6\end{array}$ \\
\hline $\begin{array}{l}\text { Individual activities - } \\
\text { partially involved }\end{array}$ & 6 & $\begin{array}{l}25,0 \\
15\end{array}$ \\
\hline Little or no involvernent. & 3 & $64 \%$ \\
\hline TOTAL & 26 & 59 \\
\hline
\end{tabular}

85

CELI PERCEAYTS BASED ON COLUIAN SUISS

CHI-SQUARE STATISTIC $=34.0567$ WITH 4 DEGREES OF FREEDOR

(SIGNIFICANT AT 0.001 IEVEL)

To not only present the knowledge for students, but also to present means by which students can becomo actively involved In doing maningful activities for the good of the envirosment is a difficult task. Since the school is the source of much involvement, ono problem a course should consider is how to get the school tied up with the community organizations that are involved in environmentel issues. At the very least, a course 
should present information to the students that such organizations do indeed exist. Even more important, a course could teach students how to do things on personal level -- recycling, conserving materials and resources, writing letters to the legislature.

Students were also asked how they would change their life style if it meant having a better environment. There was a significant difference in how the informants and random students responded to this question, particularly whether they responded spontaneously or whether they had to be prodded, to be given a suggestion before they could respond. The results are found in Table XXX.

Wen though the random students had to be prodded more, as indicated in Table $X X X$, there were no significant differences in the content of their responses in contrast to the informants. 89 percent of the informants and 75 percent of the randcm students agreed that they would linit their families to two. 62 percent of the informants and 66 percent of the randora students supported mass transit. In recyciling they were also similar, 50 percent of the informants and 54 percent of the random students willing to recycle. Limiting their families ir size, supporting mass transit, and recycling are sone of the ways that the students would be willing to be involved in changing thein life style. Curriculum is one way of presenting information to the students about why and how they might change their life style to 
create a better quality ervironment.

\section{TABLE XXX}

WILIINGNESS TO BE INVOLVED IN LINE STMLE CHANGES

Mostly spontaneous
responses
Mostly prodded responses;
no suggestions made on
own

TOTAL

\begin{tabular}{|r|r|}
\hline Informant & Random \\
\hline $\begin{array}{r}77 \% \\
20\end{array}$ & $37 \%$ \\
\hline $23 \%$ & 22 \\
\hline 6 & $63 \%$ \\
\hline
\end{tabular}

26

59

85

CELL PERCENTS BASED ON COLUNAN SUMS

CHI-SQUARE STATISTIC $=11.3418$ WITH 1 DEAREE OF FREEDOM

(SIGNIFICANT AT 0.001 LEVEL)

Summaxy: The Awereness, Concern, And Involverent of Informants And Random Students With The Environinental Cex isis

There is a difference in the awareness, concern, and involvement of the informants as compared to the random students. Al though both groups see an ecological crisis in the world, in the Pacific Northwest, and are concerned about man's survival on earth, they differ in the reasons they give and the problems they see. Informants are more concerned with the problems of population, seeing population as the crux of most of the other environmental problems. Al though the random students also consider popuiation to be a major problem, they tended in more of the questions to be more concerned with the problems of pollution (air, water, land). Information from the ecological pictures gives support to 
the data found in the interviows. AIthough these are two different kinds of interview proceduras, the results from the data are similar, confirming the interview data. For example, the informants ranked the picture of population first. whereas the random students ranked the picture of air pollution first most of the time. Where the informants saw population as the crux of the other environmental problems, rardom students thought in terms of not enough room, or not enough land, or not encugh food. The informants more strongly doubted that technology could solve our environmental problems than did the random stucients. Informants tended to be more pessimistic about the chances that man could solve his problems in time to save himself.

Informants appeared to show coneern for the environment even before taking the course. They took the environmental crisis course because they were interested in ecology, or because they were concerned about the environment and wanted to do something to help. On the other hand, the reasons of the random students for not taking the environmental exisis course were of a different nature -- wanted to take another course, the course didn't sound interesting, had scheduling problems, heard things about the course (too much work).

The informants kere much more actively involved in ecological activities, both inside school and also out in the community and in their own homes. There were significantly fewer informants who wero not involved at all than thare were random students. It 
appears that much of the involvement of irformants resulted from their taking the enviromental caisjs courses, which is cortainly one strong geason for having such courses. If nothing else, the course erposes the students to juformation, knowledge and action. that the students can use if they wish.

If it is believed that an onvironmental crisis does exist. then the data on the arareness, concern, and involvement of the Informants as compared to the random students (as a beginning attempt), does support the contention that such environmental crisis courses are very useful, and very needed. The task, therefore, for developors of curriculun is great. 


\section{CHAPTER V}

SUMARY, CONCLUSIONS, AND RECOMUENDATIONS

\section{Sumary And Conclusions}

This study was conclucted with an admitted bias that an enviromental crisis does exist in the rorid, indicated by the increasing numbers of persons inhabiting the world, the deteriorating quality of our air and rater, and the increasingly rapid depletion of our natural resources.

The role of sociologists in helping to identify and define, let alone resolve the ervironinental crisis, has been minimal.

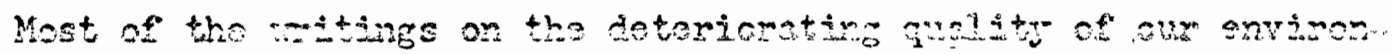
ment have come from scholars in other fiolds of endeavor. Yet collecting frightening statistios is no substitute for aralytic mociels and solidly based policy recomendations. There is great need for sociologists, and human ecologists in particular, to develop ecological theory wich could organize empirical data and initiate erpirical studies to detemine the existence of ecological imbalances in the world and suggest the nature and magnitude of corrective action.

Many suggestions have been made to help resolve the environmental crisis: population control, political action, economic action, education, and mainy others. It is education a par- 
ticularly high school curriculum -a that is the focus of this empirical study. This study focused on tho awarenoss, concern, and involvement of high school students, some of whom were taking newly organized ecology courses, some of whon were not.

Tho different kinds of methodalogy were used, both of which proved effective. The two groups of students who were interviewed at two different schools with environmental crisis courses were: 1) informants a- those students who had taken an environnental crisis course, and who were recommended by their teachers as being aware, concerned, and involved; and 2) a random sample of juniors who had not taken the course.

Comparisons of these. two groups of students provide an

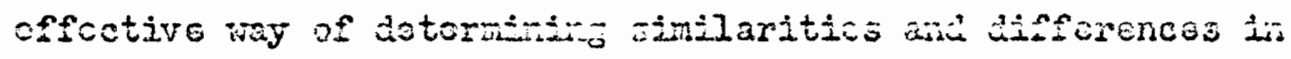
attitudes toward the envircnmental crisis, between those who were aware, concerned, and involved, and those who were not. If environmental crisis courses are going to be elective, and most of them will have to be, it is important to know the kind of student who chooses to take the course. Perhaps these are the students whose attitudes do not need changing in the first place. Alsu, since irformants from two different environmental crisis courses were interviewed, the nethodology allowed sirilarities and differences tetween the attitudes of informants to be viewed. This provided a sense of the relative influence of the two courses.

The data showed that there were some differences between the informants and tho random students in their background charac- 
teristics, and in their skareness, concers, and involvenent with ecological activities. Trformants came from smaller families, they were less religiously oriented, they spent more time in wildsrness areas, and they camped nore. They were similar to the rardorn students in that their parents have similar educational backgrounds and occupations, and they have traveled as extensively as the randori sample.

Although the informants and the random students saw an ecological crisis in the world, in the Pacific Northwest, and were concerned about man's survival on earth, they differed in the rsasons they fave and the problems they saw. The informants were much more concerned about tho problems of population, secing

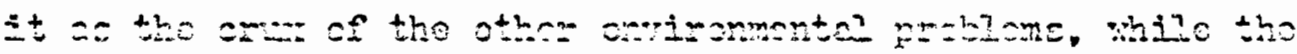
randon students viewed the problems of pollution as the more serious. The informants tended to be more pessimistic about tho outlook for man, feeling that man's chances of survival are Iinited. The informants were also more actively involved in ecological activities in echool, and outside of school. Sheh of this involvement stemmed from the courses.

The ervireorisental crisis courses in the two different schools did influence the informants' responses to some extent. Wheh of the informants' infcrmation about the environental crisis came from the courses, as did incentives for ecological involvement in activities and organizations. The Aloha informants were more concerned with population problems, the focus of that course, 
whereas the Reynolds infommants felt that awareness, attitudes, and education needed to bo chenged, more the emphasis of the Reynolds course.

There were some shortcomings in this stuay. The data were sollected at the end of the school year, when the courses wore practically over. It was therefore difficult to determine cause and effect in some irstances. For example, was it the more aware, concerned, and involved students who tended to take the enviromental crisis course, or did the course bring about more awareness, concers, or involvement?

While interview questions wisch could give more direction for curriculum development are difficult to design, the conclusions which could be drawn about curriculum from this study were limited. Although the use of the pictures, each one representin $\vec{E}$ something important ecolorically, proved to be a very successful technique, caining the attention and interest of the students, some of the pictures used tonded to be too difficult for the students to interpret, requiring too high a level of analysis. Those pictures that could be interpreted easily, as the pictures representing overpopulation, air and water pollution, and litter, yielded good data and supported the findings from the questions asked during the Intervisu.

Another shortcoming is the small size of the sample of students. However, if one wanted to use both informants and a random selection of students in a study, the size of the informant group, by its 
nature, would always be relatively small. If environmental crisis courses becone more popular (whtch they undoubtedly will), and if one interviewed informants from a number of schools, then the size of this group would be much enlarged. A larger group would allow more analyses to be undertaken. In this study the chi-square statistic was used, but furthor sub-analyses rero difficult because of the small number.

\section{Recomiendations}

The data gathered in this study might prove useful in two areas: indicating directions for new ecological theory, and guiding ecology curriculum development. The study was designed primarily to achieve the latter. For educators and persons

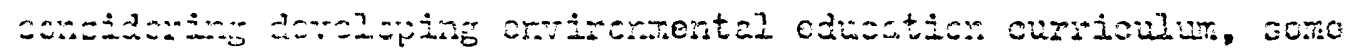
recommendations from this study are: Evironmental crisis courses definitely serve as a source of information for students, and they create in the students a concern and involvement with ecolorical activilies that is not shared by the students who do not take the course. Courses of the nature of those in this study, then, should be developed and incorporated into schools wherever there is a desire to deal with ecological matters.

Outside speakers representing various points of view appeared to be a very successful instructional technique. They influenced both the problems which the students saw as most serious and the amount of direct involvement in ecological activities. Students often became involved in the groups associated with the speakers. 
This appeared to be the key inpetus to direct involvement by the students.

Having students do research projects of their own choosing seemed to work well, particularly when those projects involved. setion on the part of the student. They arpear to give the student a chance to put to use the knowiedge that he has learned in the course. While the teachers felt such projects should bo under the guidance and supervision of the teacher, the length of these projects should be deterinined by the teacher and the student together. Some students fare better with more short-range projects, rathex than one long one. Emphasis on the interdependence of inin enabios the students to see the intorrelated nature of the eculorical cristeg athos thas just as inolatod problors.

If students locate specific environmental problems in their own community, and then take some kind of action to remedy the problem, it appears to help in making the problem more significant to him. in interisciplinsry approach also seemed to work best. Giving the students an opportunity to test out hypotheses that are presented also was effective. For exemple, the science lab was used in cne instance for the student to determine for himself whether phosinates in soap were harmful to water or not. It appeared that all of the traditional subjects taught in high schools today could become nore relevant if a current, important topic, such as the ervironmental crisis, were incorporated into them in some similar manner. 
massive for any one person to begin to tackle. New ocological theory would allow people to bettor cope with these environmental problems.

The social. organization of mankind in the future undoubtedly will bo very much affected by the environuental problems that exist, and sociologists will be much amiss if they do not begin to tackle the problems of ecological theory and research now.

Further studies need to be conducted. Since the two schools in this study were in suburban areas, it would be interesting to conduct a study in an urban setting. Interviews before and after the course would also prove beneficial. And informants need not come only from environmental crisis courses, but from ecological clubs or organizations as well.

For the most part this study developed a methodology which effectively generated a great deal of infomation from students about their awareness, concern, and involvement in ecology. The problem that needs the most thought and analysis is how to determine exactly what kind of data gathered from students would prove most useful and meaningful for developing curriculuin on the environmental crisis. Very few of the curriculum development projects in the country, regardless of size and funding, have started with clear knowledge of what the student would bring to the course, regardless of the acknowledged importance of the information. This study suffered from the conmon lack of clear knoviledge about how to relate student data to curriculum developrent tasks. 
This study has been a beginning. an exploratory project, but hopefully it will create an interest in educators and sociologists to do further research into how to change the degree of awareness, concern, and involvenent of persons with the environmental crisis. Thers are many problems to bo sumounted in this research, but more importantly, the problems of the environment need to be surmounted if man is to survive. 
Auerbach, Irwin L., and Nieger, Kenneth, "The Importance of Public Education in Air Pollution Control." Journal of the Air Pollution Control issociation, 17 . No. 2 (F'ebruary, 1967), $102-14$.

Back, Kurt W. "The V'el].-Infomed Informant." Human Organization Research: Field Relations and Techniques. id ted by Fonard t. hams and Jack J. Fieiss. Howewod, Dlinois: The Dorsey Press, Ine., 1960, 179-87.

Bates, iarston. Ths Prevalence of People. Now York: Charles Scribner's Sons, 1955.

Ber'kner, Lloyd v. "Man Versus Technology." Porulation Ellletin, XXII, Ho. 4 (November, 1966), 83-94.

Borgstron, Georg A. "The Dual Challenge of Health and Hunger -A Global Crisis." QRB Selection fie. 31 (January, 1970).

- The Hunary Planet. The Nadew inorld At the Edae of Famine. liew York: Viking lress, 1954.

Brown. Harrison Scott. The Challenge of Kan's Future: An

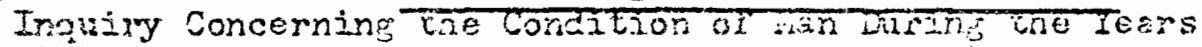

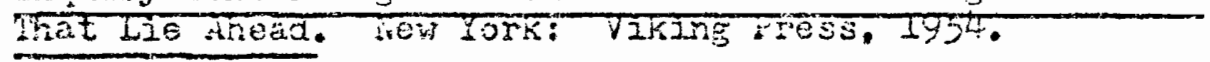
; Bonnex, James; and weir, John. The Next Hundred Yeines: Han's liatural and Technological fiesounces. Wew York: Viking Pross, 1957.

Calder, Higel. Eden Was io Garden: fin Irauiry Into the Ervironnent of Wan. Wew lork: Finehart and winston, 150?.

Carson, Rachel. Silent Spring. Greenwich, Connecticut: Fawett Publications, inc.s 1952.

Cole, Leyont C. "Man and the Air." Population Bulletin, XXIV, No. 5 (December, 1968), 103-13.

Committee on Resources and Man. Resources and Kan, A Study and Recomnendations. San Francisco: $N_{0}$. S. Froenan and $\mathrm{CO}_{0}$, 1959.

Commone, Earry. Science and Surrival. Now York: The Viking Press, 1963. 
Cook, Robert C., ed. "Halthus in Retrospect. The Stork Visits Dorking - 1766." Bepulation Eulletis, XXII, No, 1 (February, 1966). 1-5.

Crichton, Michael. Review of The Closing Circle: Nature, Han, and Technoley, by Barry Comoner. The jiew Fork Times Sook feview Section, vctober 17. 1.971.7.

Crowe, M. Jay. "Toward a Definitional Model of Public Perception of Air Pollution." Journal of the Air Pollution Control Association, 18, No. 3 (fiaren, 1968), 154-7.

Dales, J. H. Pollution, Proverty and Prices, An Essay in Policy iaking and Eononics. Toronto: University of Toronto Press, 1968.

Darling, F. Fraser. "Ecology of lian." American Scholar, 25 (Winter, 1955-6), 38-46.

Davis, Kingsley. "Population." Population in Perspective. Fdited by Louise B. Young. New York: Oxford University Press, 1968, 116-32.

DeBe11, Garrett. "Fducstion and Fonlogy." The Environmental

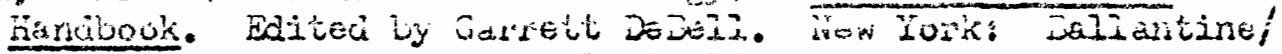
Friends of the Earth Book, 1970, 129-33.

Deevey, Edward S., Jr. "The Juman Population." Seientific American, 203, No. 3 (September, 1960), $194-8$.

Dice, Lee Raymond. Man's Nature and Nature's Man; The Ecoloey of Human Communities. Ann Arbor: University of vichigan Press, 1955.

Dubos, Rene Jules. Man Adapting. New Haven: Yale University Press, 1965. - So Iuman An Animal. New York: Scribner, 1968.

Ehrlich, Pall R. The Powulation Bonb. New York: Ballantine Books, 1958 .

, and Ehrlich, Anre H. Population, Rescurces, Environment. San Francisco: W. H. Freeman and Co., 1970.

Exirch, Arthur Alphonse. lan and Nature in America. Now York: Columbia university Press, 1963.

Fisher, Tadd. "The Many-Faceted Food Froblen." Population Bulletin, KNIV, No. 4 (December, 1958), 83-99. 
Frederick, Otto. "Population Explosion: Is han Really Doomedp" Time, September 13, 1971, 58-9.

Freeman, Orville I, World Whout huneer. Hew York: Frederick A. Fraeger, 1958 .

Gocke, Thomas K., M.D. "What is the Role of kir Pollution as A Cause of Diseasei" Amsrican Joumal of Public Health. 54. No. 1 (January, 1964, Supplement), 71-8.

Gregory, Gene. "The ivew Food Revolution." The UNESCO Courier, (March, 1969), 4-6.

Harrar, J. George. "Beyond Survival." The Next Ninety Years, Proceedines of a Conference jeld at the Californis Institute of Technolon, írch, 106?. Fesadena, Galifornia: California institute of Technology, 1967.

Hauser, Philip M. Population Ferspectives. New Brunswick: liew Jersey: Rutgers University Press, 1960.

Herber, Lewis. Crisis In Gur Cities. Bnglewood Cliffs, New Jersey: Prontice Hall; Inc.. 1965.

Hopcraft, Arthur. Dorn to Hunger. Boston: Houghton Mifflin Co., 1968.

Jarrett, Henry, ed. Resources for the Future, Environmental Quality in a Growinz Loonomy. Baltimore: Jonns Hopkins Press, 1966.

Krutch, Joseph Wood. "A Naturalist Looks at Cverpopulation." Population in Perspective. Edited by Louise B. Young. New York: Oxford University Press, 1968, 393-6.

Landsberg, Hans H. Natural Resources for U.S. Gronth. A Look Ahesd to the Year 2000. Jaltimore: Johns nopkins Fress, 1964.

Lovering, Thomes S. "Mineral Resources Prom the Land." Resources and rian. Fdited by the Conmittee on Resourses and Jan. San Francisco: W. H. Freeman and Co., 1969, 109-34.

Marx, Wosley. The Frail Ocean. New York: Coward-icCann, Inc., 1967.

McLaughlin, John. "The Ecolozy of Hunger." America, November 8. 1969, 414-?.

Herton, Robert Ko: Fiske, liarjorie; and Kendall, Patricia L. The Focused Interview. Glencoe, Dlinois: The Freo Press, 1956. 
Middleton, John r. "The Air We Breathe." Population Bniotin. XXIV, No. 5 (Docember, 1968), 114-23.

Miles, Fufus E., Jr., ed. "Man's Population Predicament." Population Eulletin, XXVII, No. 2 (April, 1971), 4-39.

- "whose Baby is the Population Problemi" Population. Eulzetin, XVI, iNo. I. (Fobruary, 1.970), 3-36.

Mishan, Ezra J. The Costs of Economie Growth. New York: Frederick A. Praeger, 1967.

Vorison, Robert. "Education for Environmental Concerns." Daedalus (Fall, 1967), 1210-23.

Ogburn, Charlton, Jr. "Why the Global Income Gap Grows Wider." Population Eulletin, XXVI, No. 2 (June, 1970), 3-36.

Organski, A.F.K., and Organski, Katherine. "Nations and Numbers." Population in Ferspective. Edited by Loujse B. Young. New York: Oxiord University Press, 1968, 172,-80.

Osborn, Pairfield. Cur PIundered Planet. Doston: Little, Brom, and $\mathrm{Co}_{0}, 1948$.

Padciock, Wjlliam, and Paddock, Paur. Faming - 19751 America's

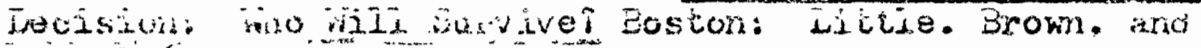
Co. 1967.

Platt, Jehn, "What We Must Do." Soience, 366, No. 3908 (November 21, 1969), 1115-21.

"Population Education - Evolution or Revolution." Population Dulletin. XXVI, No. 3 (no date giver.), 3-40.

Possony, Stefan 2 . "Technology and the Kuman Condition."

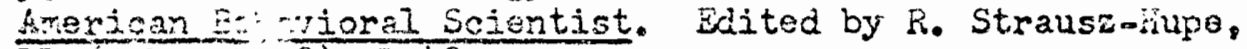
1] (Juivy, 1; 08$), 2-48$.

"Recent Mortality Trends for Emphysema and Other Chronic Fespiratory Diseases." Statistical Zulletin, Metropolitan Life, 52 (August, 1970), 1-1].

Ricker, William E. "Food From the Sea." Resources and Han. Edited by the Comititee on Resources and lian. San Francisco: W. H. Freeman and Co.. 1959, 87-107.

Rienow, Robert, and Rienow, Leona Train. Moment in the Sun, A Revort on the Deteriorating Quality of the Ameringan Envirorient. Wew York: The Dial Fress, 1967. 
Ripley, S. Dizlon, and Esechner, Helmut K. "Ecosysten Science As a Boint of Synthesis." Daedalus (Fal1, 1967), 1192-9.

Schusky, Jane; Goldner, Lester; Mann, Seymoun $Z_{;}$; and Loring, william C. "Wathodology for the study of Public Attitudes Concorning Air Pollution." Journel of the Air Pollution Control Association," 14, No. 11 (November, 1964), 445-8.

Sesser, Stanford K. "The Nation Debates An Issue: The Economy Vs. the Ervironment." The Wall Street journal, November 3 , $1971,18$.

Shepard, Paul. The Subversive Science, Essays Toward An Ecology of Han. Bdited by Paul Shopard and Daniel Weriniey. Boston: Houghton Viffin, 1959.

Strausz-Hupe, R., ed. "Society and Ecology:" American Behavioral Scientist, II (July, 1968), 1-48.

Swan, James A. "Response to Air Pollution, A study of Attitudes and Coping Strategjes of High School Youths." Eivironment and Echavior (September, 1970), 1.27-53.

"To Finl the World's Belly." Seience News Letter, 96, No. 19 (November 8,1969 ); $422-3$.

Tugweil. Rexford G. "Baxtioound Tho Frobien of pianing trid Survival." Antioch Review (Decemoer, 1949), 476-94.

vanloom, H. B. "PopuJation, Space, and Fuman Culture." Law and Conternorary Froblems, 25 (Sumer, 1960), 397-405.

White, Lynr, Jr. "The Historical Roots of Our Ecological Crisis." Science, 155, 1967, 1203-7. 
APPENDIX A

STUDENT BACKGROUND INEGRATION SHEET

Wame

Telephone Number

Address

Afo at last birthday

Numbar of children in your family

liame of High School

Year in High School. Junior; Senior

How long has your family lived in your present home?

B.ow would you environmentally rate the cormunity you live in? Excellent; Good; Fair; Poor; liot sure

Indisetse the twpe of communty in which you live: Urban; - Suburban; Paral; Other

What does your father do for a living?

irdustry (place of work)

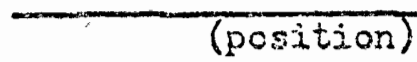

Does your mother work? If so, what does she do?

What is the last year of education completed by each of your parents?

Facher: Nother: grade schnol grade school
high school $\longrightarrow$ high school
college
graduate school Erade school hi.gh school. coileze graduato school.

What is your religjous proference? Protestant Catholic Jewish other
What is the roligious preference of your parents?

$$
\text { Protestant }
$$

Cátholic Jewish cther 
What is your political preference?

\begin{tabular}{l} 
Republican \\
Democrat \\
\hline
\end{tabular}

Where do yau receive most of your information on ecological problems? television films radio

nagazine articles
nowspaper articles
__books
_ government agencies
discussion groups speakers friends other

Do you believe that most of the students in your school are concerned about ecology? yes; no; uncertain

The ecology crisis can be solved by the application of technology. strongly agree; agree; uncertain; strongly disagree disagree; - whrongly disagrao

What is your major interest in environmental issues, or ecology? conservation population societal values and priorities natural resources air poliution water poliution

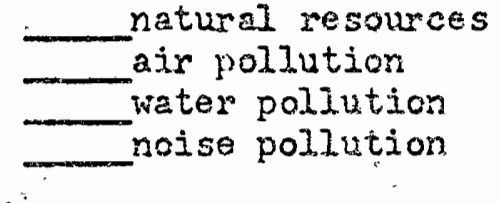
recycling urbar problems food problems ecological systems otizor 


\author{
APPENDIX B
}

\title{
INTERV IEW GUIDE
}

1. What do you consider to bo the three most important ecological problems in the world?

2. Do you see an ecological crisis in the woxld? (problems serious enough to be a crisis?)

in the Pacjic Northwest?

3. Do you think man's survival is sndargered? Why or why not? Are you optimistic or pessimistic ebout his chances?

4. A. Why did you sign up for the ecology course? (informants)

$B_{e}$ What is the major emphasis of your ecology course? (informants)

C. Did you know there was an ecojogy course being offered? (random) Why didn't you take the course?

D. What are the major activities and interests that are pursued in your ecology club? (if in club or crganization)

E. What ecological books have you read on ecology that have influenced you?

5. Have you ever tried to do anything about the ecological problems? Specifically what?

A. In school

B. Outsids of school

C. How did you become ecologically involved? (informants)

D. Why did you become ecologically involved? (informents)

E. Have other students become involved for the same reasons as you? (informants)

F. What are other students doing? (informants)

G. Would they agree with you on your cholce of ecological problems, and with jour concein? (Informants) 
6. What specifically are you doing, and ara willing to do, to changs your life style if it meant having a better environment?
A. Would you support wass transit?
B. Would you limit your family to two?
c. Would you recycle?

7. A. What are your loiswre activitios that take place outdooors?

B. What opportunities have you had to go to wilderness areas? How of ten have you gone?

C. Do you camp?

D. Are most of your activities centered in and around Portiand?

E. Where have you traveled in the United States?

8. A. Are there any ecological problems in your neighborhood? Spocifically, what are they?

B. Have you, or any members of your family, made any offort to correct these ecological problems? if so, what specifically?

9. Is thero any cologion problem that woule concem you enough that you would becorne actively involved? (random) What, in particular?

10. What doss ths word "ecology" mean to you?

11. What suggestions would you make for a course in ecology to make students aware, concsrned, and involved? Is there anything that you would specificalily like to learn if you took the ecology course? (random) 
1. How did the Enviromental Crisis/Man-in-Environment course come into being? Why? When?

2. What has been your role in bringing this course into boing?

3. How many students took the course this year?

4. What kind of student tended to take the course? Why? Is this kind of studen't representative of the socioeconomic status of the school?

5. What has been your major emphasis ir teaching the course?

6. What has comprised the course in contenti

7. What has couprised line colvse in activiliest

8. What kinds of activities seemed to work with what kind of student $?$ Are there any activities that did not seen to work? Why?

9. Do you feel that there has been a change in the students' ecological awareness, concern, ond involvenent since taking the ecology course? For how many students? Wisat are some spocific examples?

10. What have been your major ecological concerns and involvements? 


\section{APPENDIX D}

\section{VARIABIF DICTIOUARY}

Colurm

Catogories

$\underline{\text { Code }}$

Informant Random

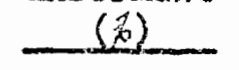

(i⿱i)

\section{BACKGROUND DFORMATION SHEET}

$4-6$

Student Idsrtiflcation

Reymolds 101.- -146

Aloha 201 $=0-252$

7 Randon or Informant

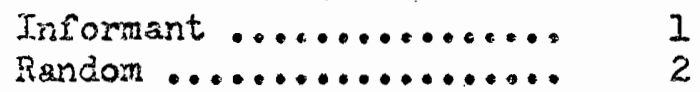

$8 \quad$ Age at last birthday
$16 \ldots \ldots \ldots \ldots \ldots \ldots \ldots$
$17 \ldots \ldots \ldots \ldots \ldots \ldots \ldots \ldots$
18

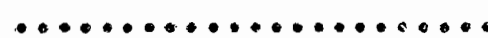
$25 \ldots \ldots \ldots \ldots \ldots \ldots \ldots$
3
2
3
4

$9 \operatorname{sex}$

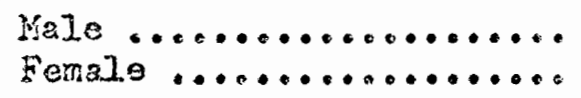

1

2

54

46

51

49

10 Number of children in family

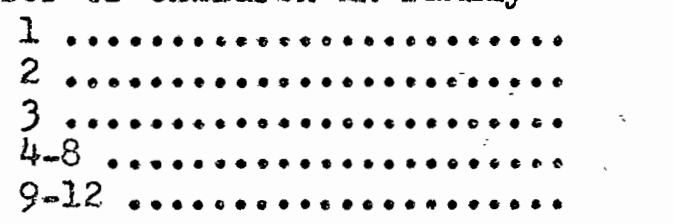

1

2

8

19

50

19

$5 \quad 4$

\section{0 \\ 24 \\ 48 \\ 2}

11 Year in high school

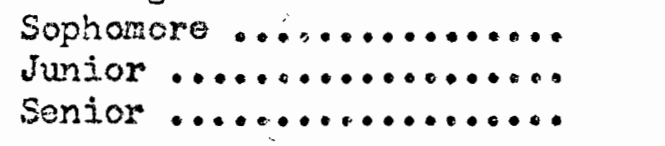

1

2

0

3

0
54
46

100

0

12 Length in present home (years)

$0-1 \ldots \ldots \ldots \ldots \ldots \ldots$

$2-5 \ldots \ldots \ldots \ldots \ldots \ldots \ldots \ldots$

$6-10 \ldots \ldots \ldots \ldots \ldots \ldots \ldots$

11 or mora

1
2
3
4

8
42
35
15


13 How would you environmentaliy rate the commuity you live in?

fircellent

Good

1

Fain

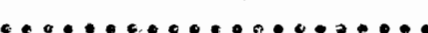

Poor

(E)

(b)

Not sure

14 Indicate the type of community

in which you live.

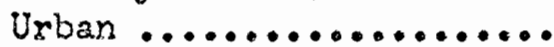

Suburban ...............

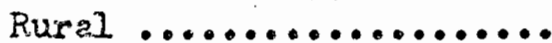

Other ..................

No response

2

3

4

5

$\begin{array}{rr}4 & 9 \\ 39 & 59 \\ 39 & 31 \\ 15 & 2 \\ 4 & 0\end{array}$

$=$

15 Occupation of Father

Upper level professional.. Middle level professional.

Lower level professional..

Technical and business ....

Shizied trassz...........

Semi-skilled

1

1

3

4

5

Unemployed.

...........

Dnemployed.................

Don't know no response...

1

1

16 Occupation of Mother

Upper level professional.

1

Middle level professional.

2

Lower level professional .

Technical and business

Skilled trades ...........

Semi-skilled .

Unemployed

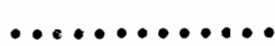

Deceased

............

Doceased ...................

Don't knows no response .

3

4

$\begin{array}{rr}0 & 3 \\ 8 & 3 \\ 12 & 14 \\ 46 & 35 \\ 15 & 19 \\ 15 & 7 \\ 0 & 5 \\ 12 & 5 \\ 4 & 9\end{array}$

17 Iast year of education completed by father

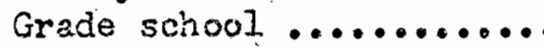
iigh school

Colleg 0.00 .00 .0 .0 .0 .0 Collego $\ldots \ldots \ldots \ldots \ldots \ldots \ldots$ Graduats sehool .......... 
Colums

Categories

Code

Informant Rardom

18 Last year of education

completed by mother

Grade school

High sehool

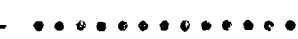

$\ldots \ldots \ldots \ldots \ldots \ldots$

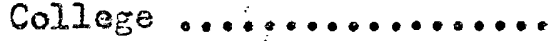

Graduate school .........

Don!t know, no response...

(i)

(苟)

19 Student's religious preference

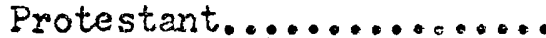
Catrolic ............... Jewish $\ldots \ldots \ldots \ldots \ldots \ldots \ldots \ldots$

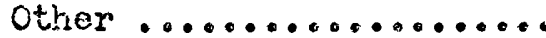
No religious preference...

0

2

1

64

2

39

15

20 Parents' religious preference Protestant ..............

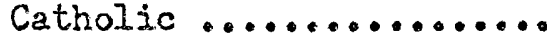
Jewish ...............

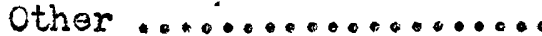
No religious preferonce...

$\begin{array}{rrr}1 & 50 & 71 \\ 2 & 8 & 12 \\ 3 & 0 & 0 \\ 4 & 1.9 & 10 \\ 5 & 23 & ?\end{array}$

21 Student's political preference

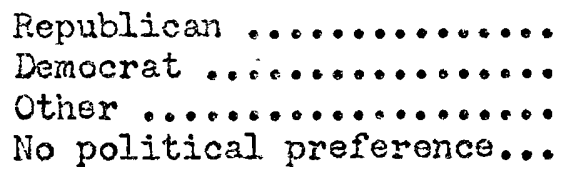

22-23 Where do you receive most of your information on ecolosical problems?

Television .............

FjIms $\ldots \ldots \ldots \ldots \ldots \ldots \ldots$

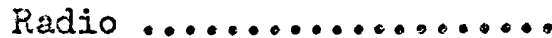

Magazines ..............

Newspapers .............

Books ...................

Government azencies ......

Discussion groups ........

Speakers ...............

Friends ...............

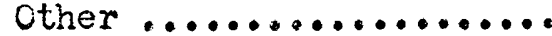

Checked many responses.... 
24 Do you beliove that most studonts in your school are concerned about ecolory?

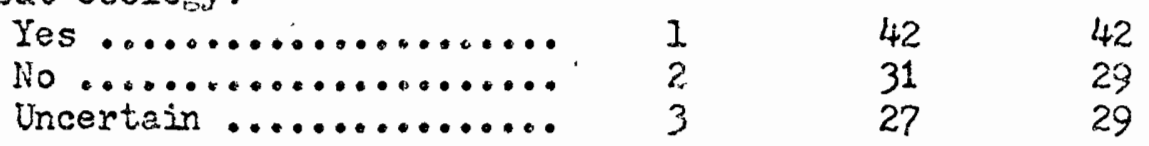

25 The ecology crisis can be solved

by the application of techrology. Strongly agree .......... 1 Agree ................. Uncertain ............. Disagreo .............. Strongly disagree ....... 5

1

2

26-2? What is your major interest in ervirormental issues?

Conservation .............

Fopulation .............

Sociotal values and

priorities ............

Natura? zacouncos ....

Air poilution ............

Water pollution ..........

Noise pollution ..........

Pollution in general .....

Recyciling ..............

Urban problens ..........

Food problems ...........

Ecological systems .......

Checked many responses ...

2

\section{QUESTIOWAIES}

28 That do you consider to be the three most important ecological problens in the vorid?

Population, air pollution, water pollution ........... Population, scarcity, and. pollution ............... Population, pollution, other .................. AIl poliution ........... Pollution and others ...... Population, crux of all .. 
Informant Random

Column Categories

Do you see an ecological crisis

in the world?

Yes .................... I

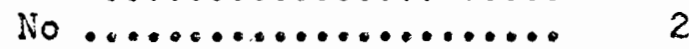

Don't krow .............. 3

1
3

85

63

Not yet, will be if keeps

going

4

4

5

4

30 Reasons

Mentions specific problem

1.

There is a crisis in certain

areas ....................

2

8

25

If something isn't done,

there will be a crisis....

Other reasons ..............

No reasons given

n........

If specific problem is mentioned, what is that problem(s)?

Population. ...............

Air pollution .............

Water pollution $=0 . \ldots, \ldots$.

iand poisulidon ...........

Pollution in general

Awareness, education,

attitudes ...............

Scarcity (resources, food

production, space) ........

Other problens .............

Not applicable ............

5

19

22

28

$3 \quad 8$

$77 \quad 49$

4

5

i

12

14

2

20

$0 \quad 7$

410

6

27

14

15

3

8

10

9

0

29

32 Is there an ecological crisis in

the Pacific Northwest?

Yes ....................

No

1

46

24

Don't know ...............

2

15

14

Not yet, rot as bad as

other places

4

31

54

33 Reasons

kentions specific probiem

1.

50

49

There is a crisis in

certain areas ............

2

35

32

If something isn't done,

there wiIl be a crisis ...

Cther reasons ............

3

No reasons given

15

0

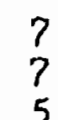


Column

34 If specific problem is mentioned, what is that problem $(s)$ ?

Population, or population and pollution .................. Air pollution .............. Water pollution .......... Land pollution ............ Pollution in general. Awareness, education, attitudes ................ Scarcity (resources, food production, space) ........ Other problems ........... Not applicable ...........
Informant Random (品) (\%)

$\underline{\text { Code }}$

35 Do you think man's surviva]. is endangered?

Yes .................. I

Yes, if keeps going .......

No .....................

Not yet, getting to be ...

Not applicis?e

1

2

3

4

5

6

9
19

12

15

0

12

0

15

23
19

10

14

0

19

3

3

24

36 Are you optimistic or pessimistic about man's chancesi

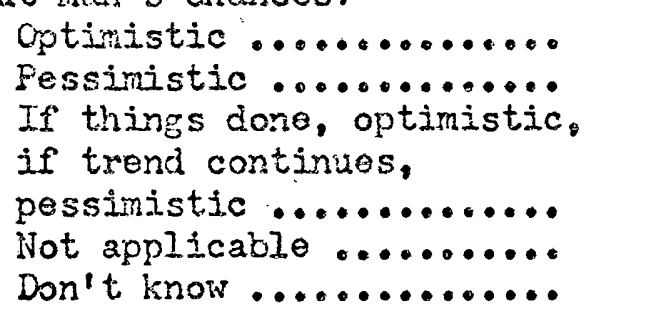

37 Reasons

Jentions specific problem

3

31

39

Deperds on man's attitudes, awareness, and concern ...

2

39

10

Will depend on ran's

adaptation ...............

The crisis is in tho futurs

Other reasons

15

14

Not applicable 
Column

38 Why are you optinistic or pessimistic?

lian has or will find solution Adaptation (living vs. survival) ................ Mentions pasticular problem Not applicable Other reasons
Code

Informant Randon

39 Why did you sign up for the ecology course? (irisormants) Interested in subject of ecology .................. Wanted to learn more about the problems ............. To learn more, to holp.... Credit requirements, choice of courses avaizable .....

40 What is the major emphasis of your ecology course? (informants)

Knowledge (made aviare of problems) ................. doing something about them Poople's attitudes need changing about the crisis other reasons ............

41 Did you know the ecology course was being offered? (random)

Yes .....................

No

other reasons ............
1
80

17

4

42 Roasons for not taking course? Wanted to take another ... Didn't sound interesting.. other requirements........ Didn't understand it ...... Could learn elsewhere..... Heard things about course. Other reasons ............ Not applicable ........... No reasons given 
Columm

43 Will you take the course next year? (random)

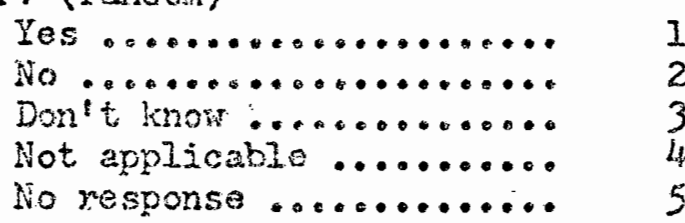

44 Readings in ecology that have influenced you?

Littile or no reading .....

lientions specifj.c bonks, articles ................. Few articles, mazazines . lientions specific magazines Class lectures, discussions Can't ramember

45 Involvenent in ecological activities, in school?

Earth Day (attended or did something that day)........

school orguniagtions : 0.

LLne-term activities .....

Shout-term activities ....

Course involvement ........

No involvenent

46 Involvenent in ecological activities, cutsicie of schocl?

(Very involved and tries to

convince others to be ....

Cvery involved .............

Partially irvolved and tries to convince others to be.

(Partial involvenent....... istitle or no involvement.

1.

2

3

4

5
- 19

8

39

23

12

47 How did you become ecologically involved?

Not applicatle.

1

Through other people, or

friends..................

SThrough courseltsachers...

Through parents...........

Through the media.........

other rays. 
Column

48

49

Have other students become involved for same reasons as you? Yes ................... Qualified yes ........... Don't know ….......... Not applicable .......... Other reasons

Not applicalle Through another person: friend, teacher, parent... Readings or the media..... Concern for environment... Through the course........ other reasons

1 2 3 4. 5 $\frac{1}{2}$

50

51

52

why did you become ecologically involved?

$t$ are other students doing? Don't knon .............. Wentions specific names... Knops of othars, no nares Not applicabie .......... Other responses ..........

Would they asree with your choice of ecological problems and your concern?

Yes .................. I

Qualified yes ...........

No ....................

Qualified no............

Don't know ..............

Not applicable ..........

Other reasons

What specifically are you doing, or willing to do, to change your life style? Jany spontaneous responses lostly prodded responses.

Specifics on mass transit

Informant Randorn

Code

(i)

(3)

$\begin{array}{rrr}1 & 12 & 5 \\ 2 & 39 & 2 \\ 3 & 23 & 0 \\ 4 & 0 & 92 \\ 5 & 15 & 2\end{array}$
hould support it, pay taxes 1. 
Column

54

55

$$
\begin{aligned}
& \text { Specifics on recycling } \\
& \text { Would recycle............ } \\
& \text { Would not recycle, would if } \\
& \text { had to (not on own) ...... } \\
& \text { Not applicable ........... } \\
& \text { Other responses ......... }
\end{aligned}
$$

Would limit sanily to two

Would not limit family....

Not applicable ..........

other responses ..........

56

What are your leisure activitjes

that take place outdoors?

Outside, away from home

activities (hike, fish,

backpack, hunt)

Athletics

Cutside, around home activi-

ties (walk, yardwork, play

vith animais).

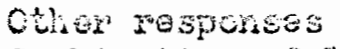

Combination of 1 and 2 ....

Combination of 1 and $2 \ldots$

Not applicable

57 hinere do you spend most of your tine?

\section{Indoors ................}

Outdoors $\ldots \ldots \ldots \ldots \ldots \ldots \ldots$

$\frac{1}{2}$ and $\frac{1}{2} \ldots \ldots \ldots \ldots \ldots \ldots \ldots \ldots$

Not applicable

58 What opportunties have you had to go to wilderness areas?

\footnotetext{
Many opportunities .......

Few opportunities
}

What kind of camping do you do, if you camp?

Tent camps or backpacks ..

Trailer camps ...........

Does not camp .............

Not applicabie
1

2

3

12

69

1.2

- 8

1.

2

69

31

42

58
15

51

34

0

\section{5 \\ 0 \\ 5}

54

22

22

2


Column

60

61

Number of times you visit the city of Fortland?

$1 X$ week ................

2-3X week .............

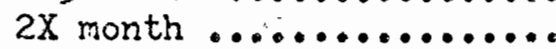

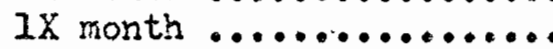

Harcily ever ............

Not applicable ..........

Yes

62

Are there any ecological problens in your neighborhood? what?

Fentions a specific problem

(slew behind our house)....

Geners] problem (air

poliution) .............

No problems
Code

Informant Random

(i)

12

0

7
10

$\frac{1}{2}$

3

42

19

27

54

22

5

I

2

3

4

5

6

7

1

54

27

2
3

27

19

24

49

63 Have you or any family member

made any effort to correct these

ecological problems?

Yes, specifically did

something ..............

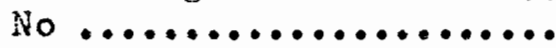

Not applicable .........

1

2

3
19

15

22

31

48

64 Is there any ecological problem that would concern you enough that you would beccme actively involved?

If it affected me personally, got really close to me ....

There's nothing one person

can do ..................

If it gets bad enough ....

Gentions specific problem or

Sorganization to join ......

No, don't know ............

Other responses ...........

No response ..............

Mentions general problem

(air polliuition, population) 
Colum

65

66

67
What doos the word "ecology" mean to you?

The enviroment, study of the environient, nature... Conservation, preservation of our ervironment ........ The problems, condition of our environnent .......... Interrelation of species... Balance of nature, balanced ecosystems …............ Other zesponses ......... Don't know ................ Kentions specific problems

Suggestions for a course in ecolony to make students aware, concerned, and involved?

Field trips to see hoy bad it is ............... Course serves the purpose Speakers, specialists..... Cet involis?. No ideas .............. Not applicable Other reasons

If you took the course, what wovld you like to learn?

What an individual can cio, how to get involved ...... Mentions a specific problem Learn how bad the problens really are .............. Learn what needs to be done (costs, laws). Other responses .......... No ideas, not interested..

Not applicable

RANIING OF PICTURES (Deck II)

28-43 Ranking of picturos in order

44 What does the picture represent?

(17)

Cverpopulation, population

explosion

1

Other 
Columin

45

46

47

(20)

48

Does the U.S. have a population problem?

In certajn areas (cities)

Yes, all over ............

It will have one, if keeps going as is .............

Partially, not as bad as other countries ...........

Other reasons ............

Not applicable

What does the picture representi

Air pollution, industrial.

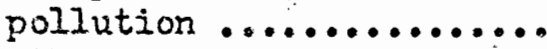

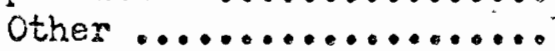

Why is air pollution a problem?
$\underline{\operatorname{Cod} \theta}$

Informant kandom

(它)

(7)
12

20

37

5

15

10

$\begin{array}{rrr}\frac{1}{2} & 8 & 29 \\ 3 & 50 & 19 \\ 4 & 0 & 17 \\ 5 & 8 & 17 \\ 6 & 4 & 5 \\ & 31 & 14\end{array}$

1

2

96

98

2

Affects life - health and

survival ..............

Economic reasons (apathy by

1

35

75

industries).

42

10

other reasons

2
3

23

15

49 Who is responsible for doing something about the problem?

The goverment (iaws).....

1

12

5

People who do the polluting

and if they don't, the

government...............

Everybody (oeple, factories, government).............

Government through the

people .................

Not applicabio

2

15

44

3

50

41

4

6

$\begin{array}{rr}15 & 7 \\ 8 & 0\end{array}$ 
50 What does the picture represent?

Water pollution ..........

other ...................

Don't know

Code

(3)

(b)

$\ldots \ldots \ldots \ldots \ldots$

$\frac{1}{2}$

85

78

$4 \quad 1.4$

12

9

51 Why is water pollution a problem?

Water needed for life (rish, source of food for humans).

Attitudes and actions of

1

46

57

people (economic, ignorance, don't care) .............

Not applicable ..........

other reasons

2
3
4

46

27

4

20

52 Does it bother you to see a dead fish?

Yes, like fishing, fish

alive .................

2

12

15

Useless killing - a waste

and repercussions for the

life cjele ...............

Yes, don't like to see dead

2

31

39

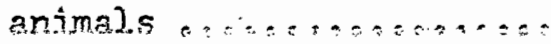

If continues, could be man

No ...................

Not applicabie ..........

other reasons ...........

3
4
5
6
7

3

4

9

31

10

15

5

53

What does the picture represent?

Litter, land pollution ...

other ..................

Not applicable

1

77

100

19

0

54

Why is litter a problem?

Ruins beauty gives bad

impression ................

Disposal problems.........

1

39

49

Hazard (health, accident,

fire)................

Other reasors ...........

Not applj.cable ..........

?

19

3

820

$31 \quad 10$

55 Why do people litter?

Attitudes and actions(don't

care, laziness, ignorance)

1

Not enough containers ....

2

Other ...................

Not applicable

3

$\begin{array}{rr}85 & 86 \\ 4 & 7 \\ 4 & 5 \\ 8 & 2\end{array}$


56 Do you litter?

Yes, think about it more,

less than cefore .........

Yes, nothtne big̈.........

ito .....................

No, when I think about it.

llot applicable...........

1

2

3

4

(i)

(i)

What does the picture represent?

(7)

The earth, world, planet..

The world and all its

probleins ...............

Don't know, don't under-

stand .................

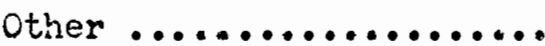

Space program ...........

Air pollution, smog ......

1

1

58

66

2

12

10

3

5

0

12

12

8

32

14

$31 \quad 32$

$8 \quad 12$

39

10

58 Ecological pictures associated with this picture?

ilo, no proslems ..........

Think of al] the problenis,

or mentions sunse ..........

lost important thing.

represents everything.....

How beautifil it is from a

distance (now we nant it to

be, what it used to bo)...

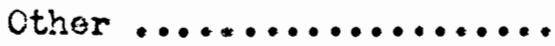

liot applicable

1

4

17

i

39

42

3

15

15

4.

19

10

5

23

10

5

59

What does the Eicture represent?

Space progzan, rocket ....

Technology, progress......

Follution of some kind....

Wiaste of money ...........

other ..................

1

2.

35

19

54

3

8

9

4

5

35

22

12

3

60 Any ecological problems in picturei Are you in favor of the space pregram?

Wastes money which could be used on earth's problems.. New place of inhabitation. Creates pollution ........ Search for knowledge ...... Other .................. No problems

1

62

37

2 
What does the picture represent?

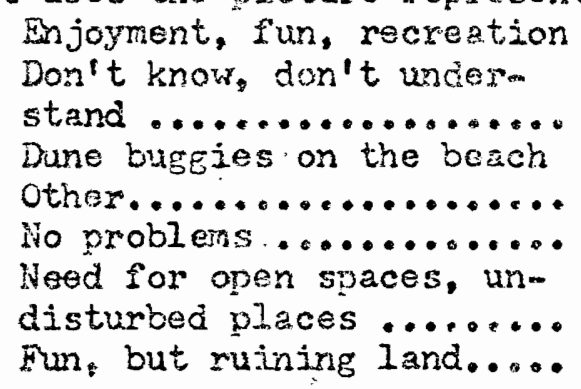

6
7

62 Ecological problems associated with picture?

No problems ..............

Land problems, tearing up

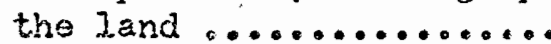

Not hurting the land because

1

0

31

it's desert.

t......................

2

29

12

Noise pollution, need for

quiet areas.............

Ais pollution, oil slicks

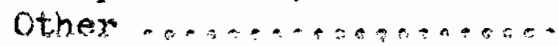

Not applicable .........

3

23

9

4

23

12

5

6

7

8
23

12

20

5

What does the pictire represent?

Don't know dion't under-

stand .................

Boy trying to understend

plant, watching it grow...

Importance of the reletior.-

ship of man and nature.....

3.

0

10

Next generation and theix

life on earth (both boy and

plant are siarting 1 ife $)$. :

Boy looking sad (last plant

on earth, plant won't grow)

other................... 